TE WHARE WĀNANGA O TE ŪPOKO O TE IKA A MĀUI

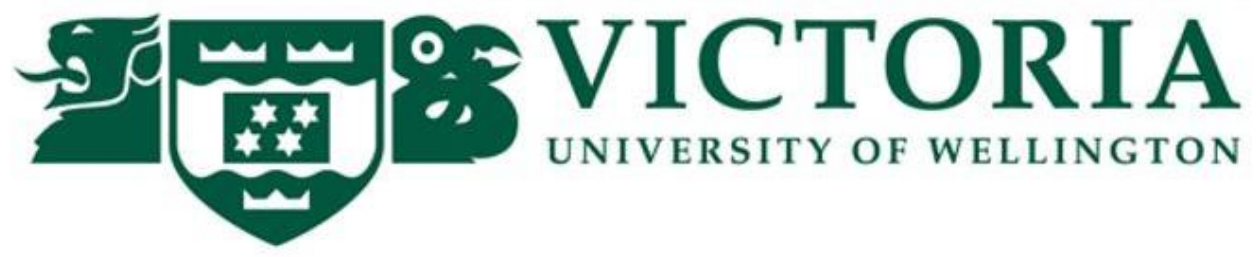

School of Geography, Environment, and Earth Sciences Victoria University of Wellington

New Zealand

\title{
Exploring Family Characteristics, Individual Motivations and Social Norms Regarding \\ Women's Access to Tertiary Education in Laos
}

\section{KINNAPHONE SOUNTHONGDENG}

Thesis submitted to Victoria University of Wellington in partial fulfilment of the requirements for the degree of Master of Development Studies 



\begin{abstract}
In aiming to graduate from Least Developed Countries status by 2020, and in joining the ASEAN Economic Community in 2015, the Government of Laos has been seeking to sustain a high rate of economic growth and to develop a skilled and proficient labour force. As such, economic development has been a focus of the government and developing skilled and proficient labour is important. Education, especially tertiary education, has also been a priority of the Government of Laos. However, the gender gap still exists in every education level with high fees just one barrier for women to get into higher education. Promoting women's access to tertiary education is important for closing the gender gap and improving women's livelihoods, as well as contributing to the country's economic development.
\end{abstract}

The research explores the main barriers to women's access to tertiary education, concentrating on family characteristics, individual motivations and social norms. Utilising a feminist lens, qualitative research has been undertaken through semistructured interviews. Thirty interviews were conducted, including women who were current students in tertiary education institutions and women who were not in any tertiary education institution. Information regarding tertiary education policies and implementation of these policies was also gathered from key information interviews and secondary information.

The research found that family financial status is the main barrier for women to continue their education in higher education. When the family budget is limited, most parents prioritise the education of males. Furthermore, the perception that women have less opportunity to gain a job than men persists widely - and acts as a disincentive for women to access tertiary education. 


\section{Acknowledgements}

This thesis was completed with support and collaboration from supervisors and all participants. First and foremost, I would like to thank my supervisor and course coordinator, Professor John Overton, for educating me in and guiding all the processes of the thesis. I really appreciate all his patience with respect to my writing, and his encouragement to keep going with the work. Thank you to my co-supervisor, Dr. Luke Kiddle, for his attention in order to improve the thesis to be reasonable and logical.

I am grateful for the positive improvement to my thesis to Esther Kiddle for her enduring work on my English to be more accurate, comprehensible and concise.

Thank you to the community heads (Dongdok and Nasangphai Village heads, Vientiane Capital) for allowing me to conduct the interviews in your communities and also accompanying me to meet target groups. I wholeheartedly appreciate everything all participants have done in giving their valuable time and the trust they have shown in opening their minds and sharing their own stories with me.

Thank you to International Student Office advisors for managing all concerns during my study in New Zealand and thank you to the New Zealand ASEAN Scholarship for giving me the opportunity to study in New Zealand and all the support during preparation in Laos and New Zealand.

Lastingly, I would like to thank you my family who support me and encourage me to be hard working including supporting my intention to study. The care taking, consulting and instruction from my family are worth so much and help me to keep on going even in the hardest times. 


\section{Table of Contents}

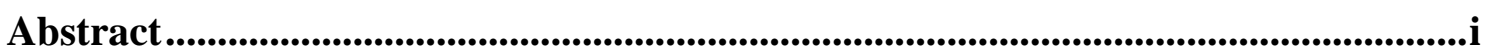

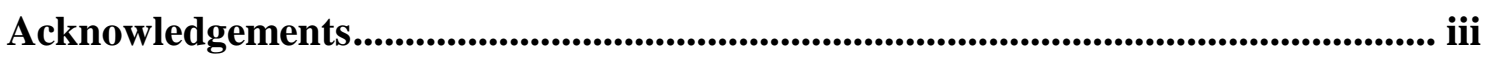

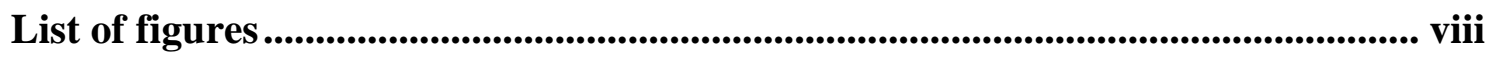

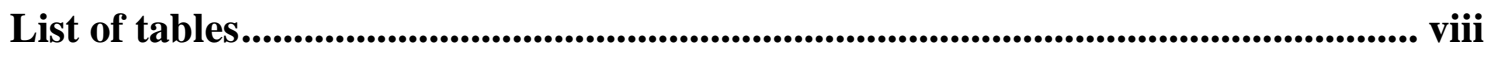

List of abbreviations .........................................................................................................ix

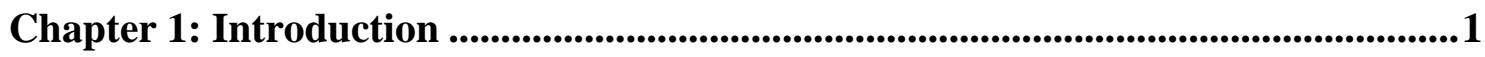

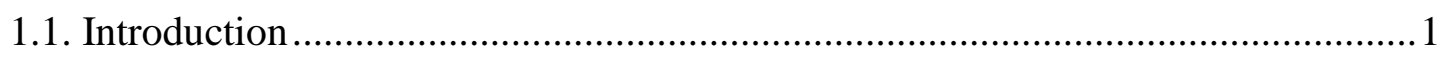

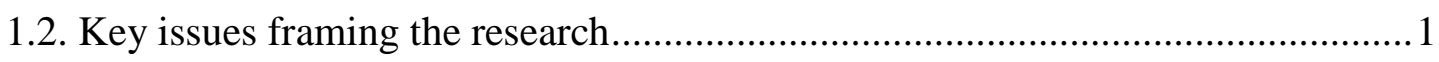

1.3. Aim and objective of the research................................................................ 3

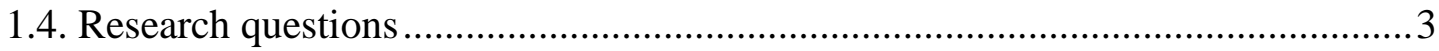

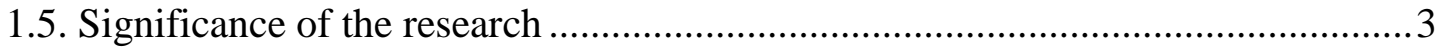

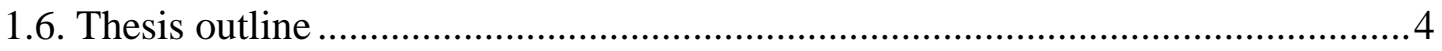

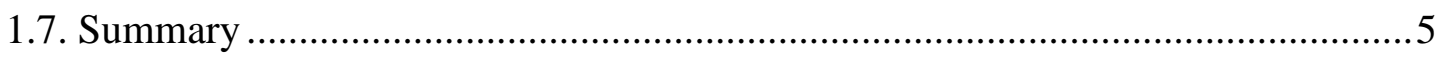

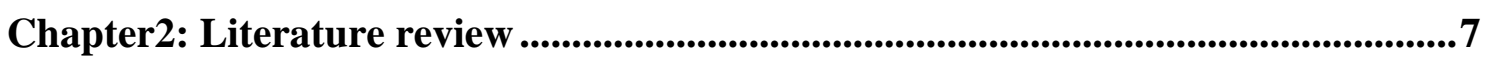

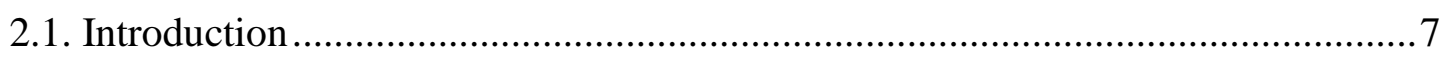

2.2. The role of women in the labour market, politics, and family ...........................

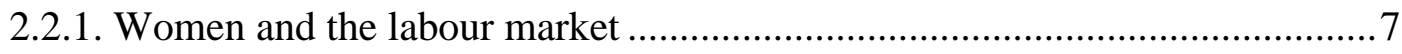

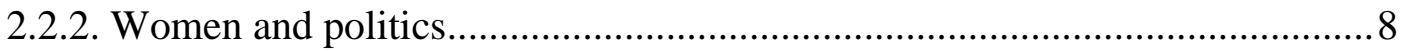

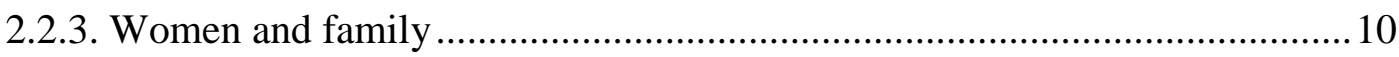

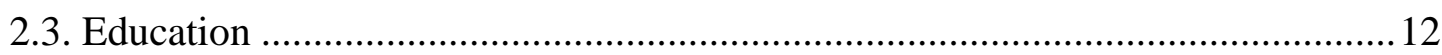

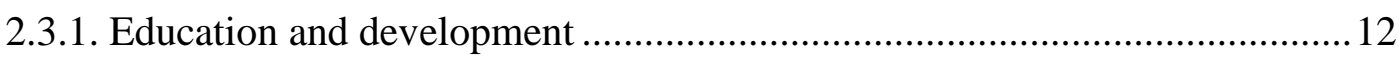

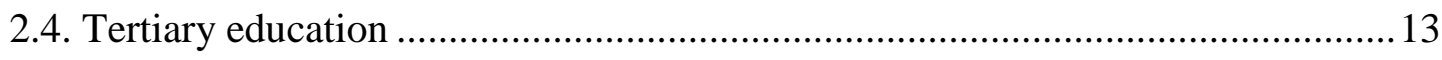

2.4.1. Higher education benefits to women....................................................... 14

2.4.2. Tertiary education in Southeast Asia ...................................................... 15

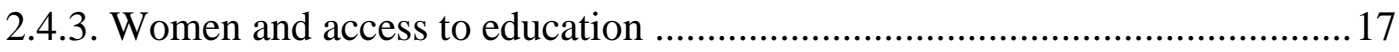

2.5. The international agenda for higher education and women's empowerment ......21

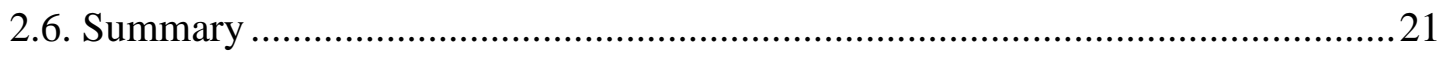

Chapter 3: Economic development, education and women in Laos.......................23

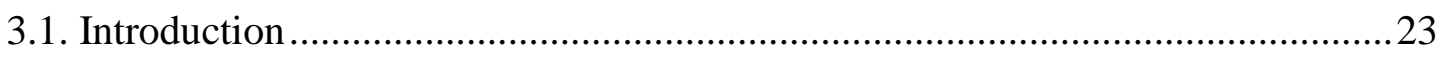

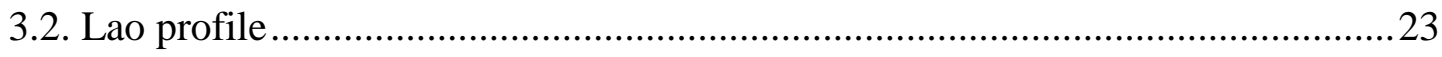

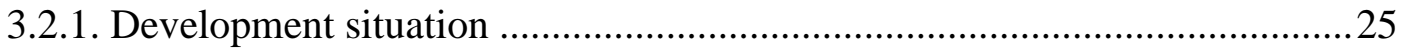

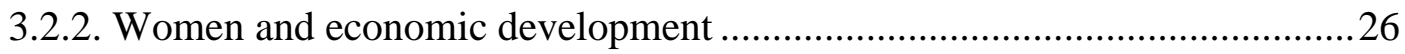

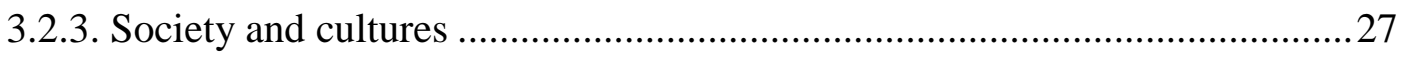

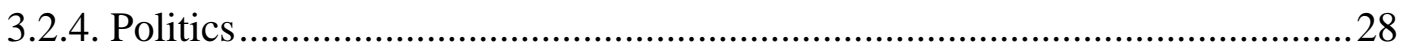


3.2.5. Vientiane capital profile .29

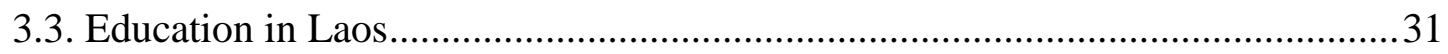

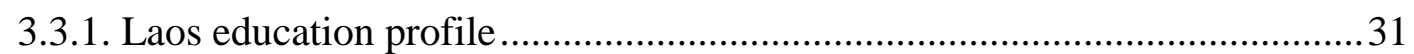



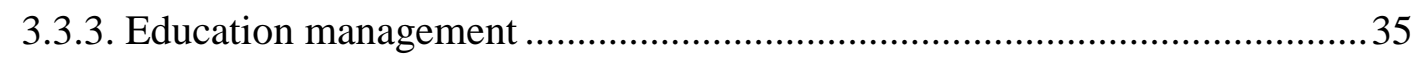

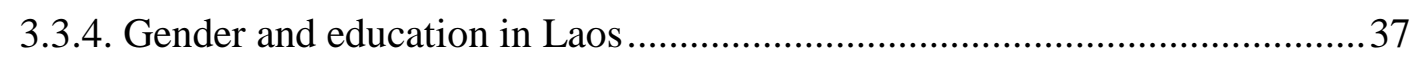

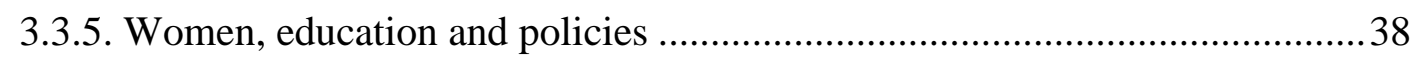

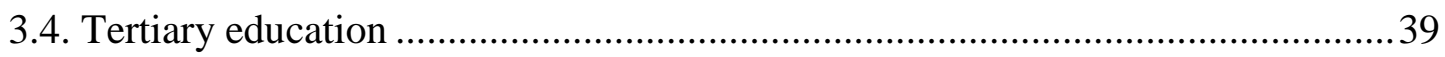

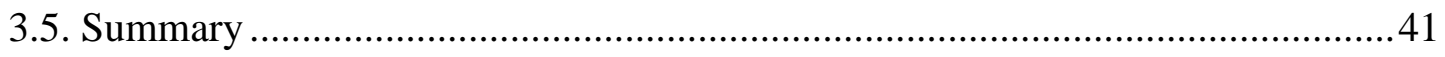

Chapter 4: Methodology .............................................................................................43

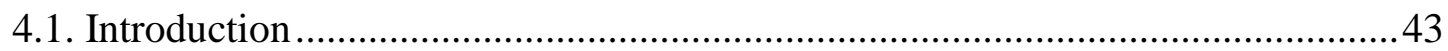

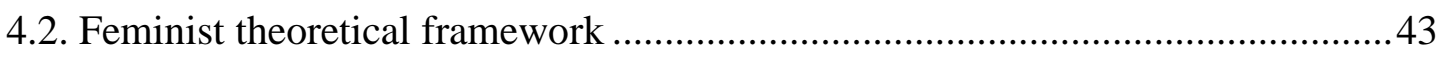

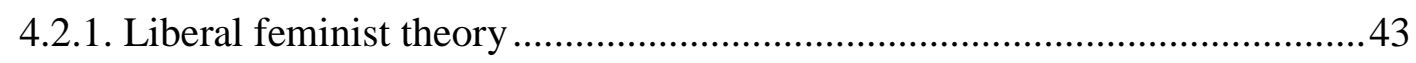

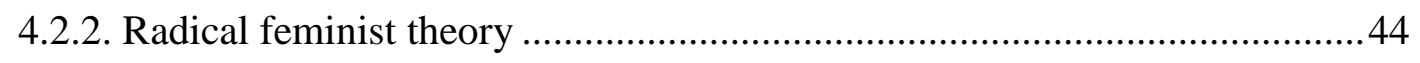

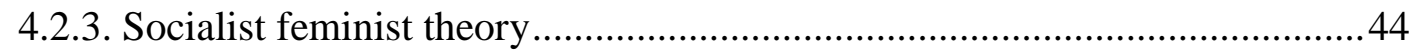

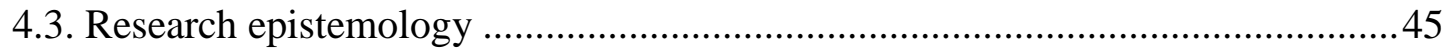

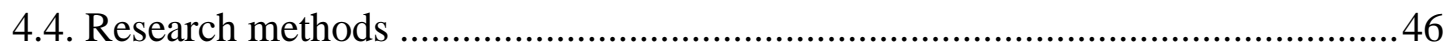

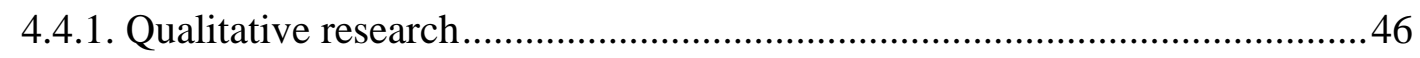

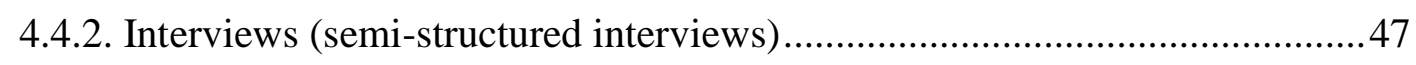

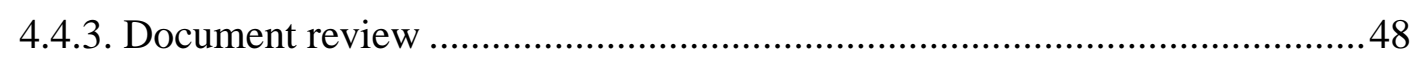

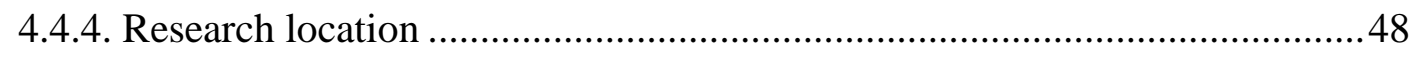

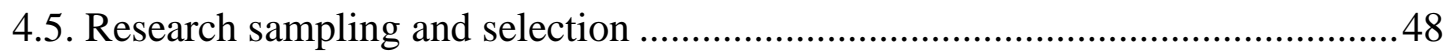

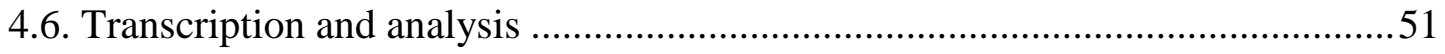

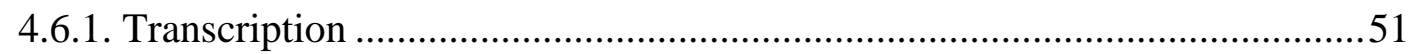

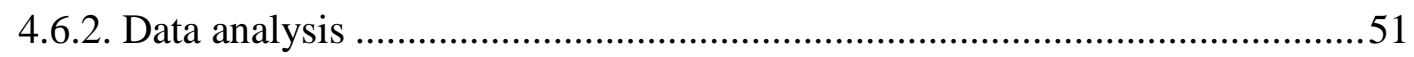

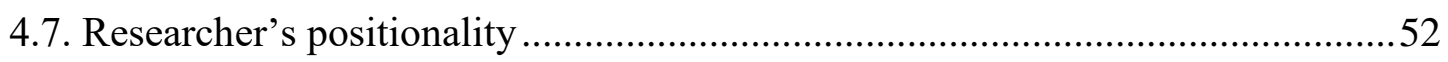

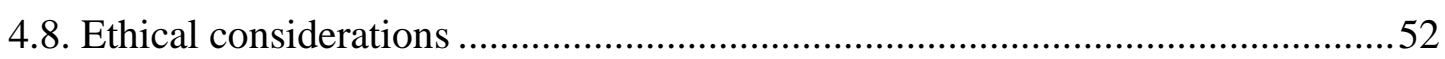

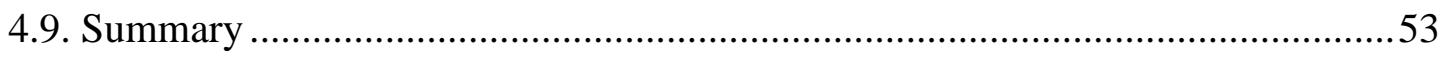

Chapter 5: Key results: Families, women's preferences, and social norms .............55

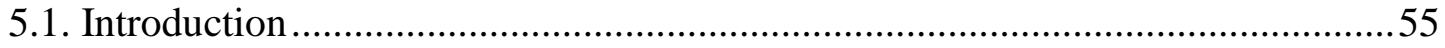

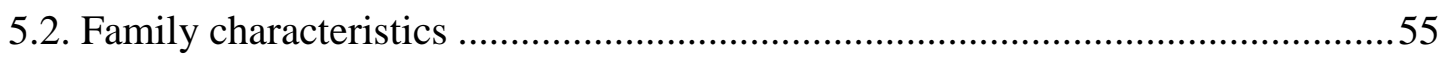

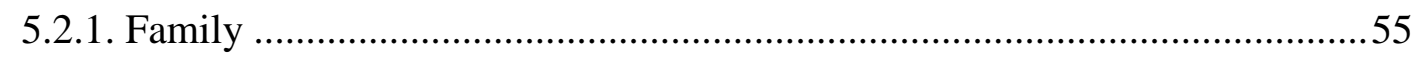

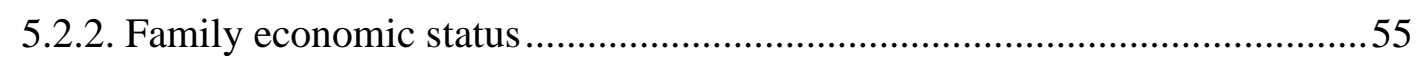

5.2.3. Parental status and family members' responsibilities ................................57

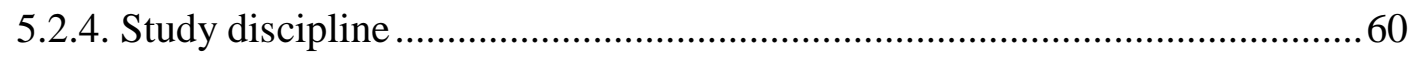




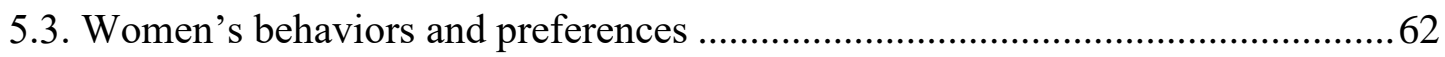

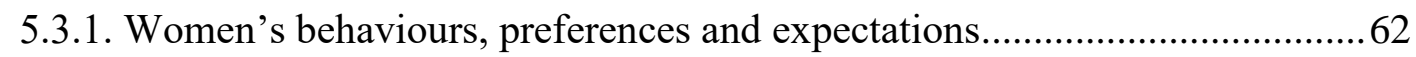

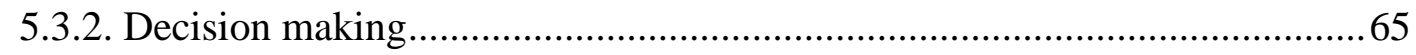

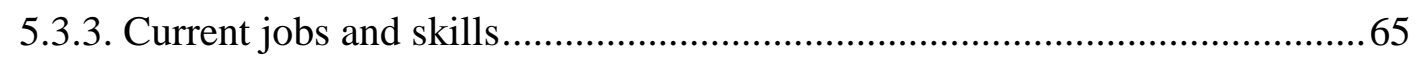

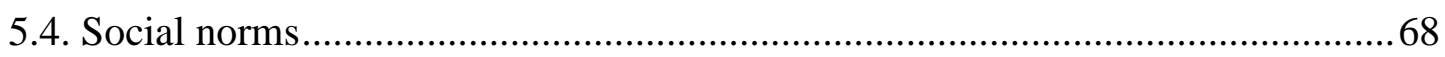

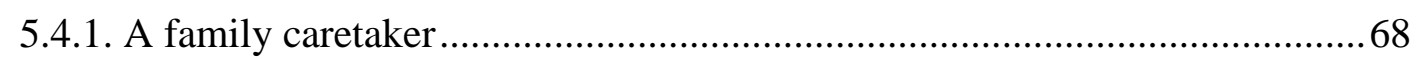

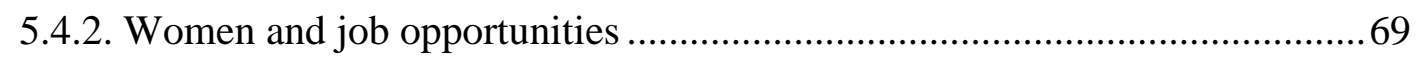

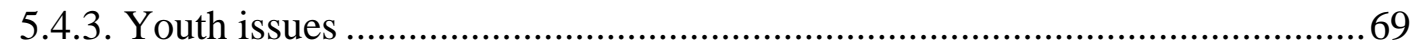

5.4.4. Women and knowledge on gender equality ............................................... 70

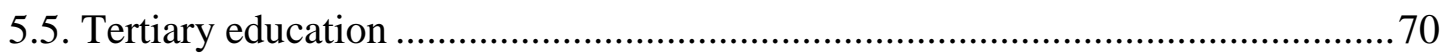

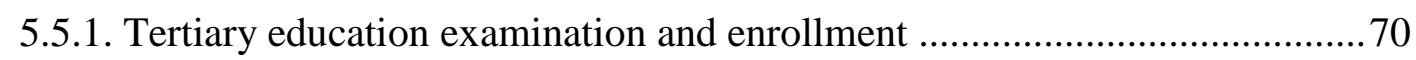

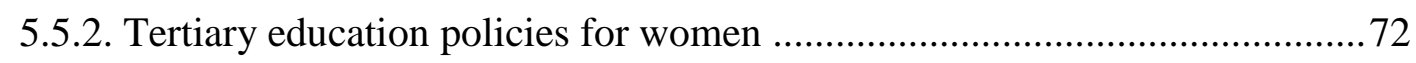

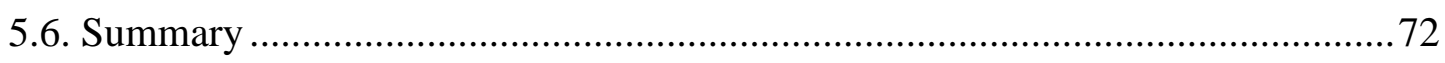

Chapter 6: Discussion: Women and tertiary education ..............................................75

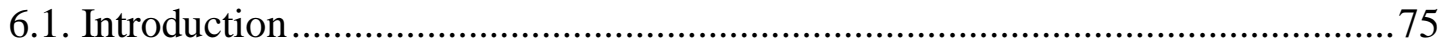

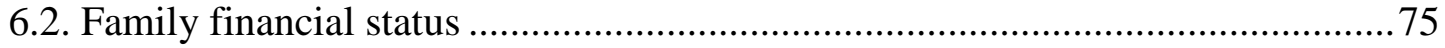

6.3. Household chores and poor study discipline (family roles) ..............................77

6.4. Work preferences and opportunities (social norms) .......................................... 78

6.5. Tertiary education information dissemination and enrollment ...........................8 80

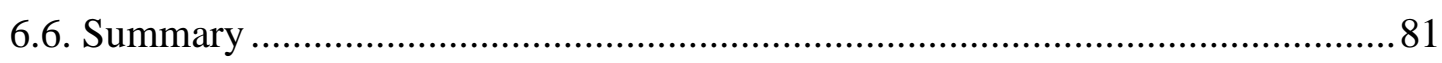

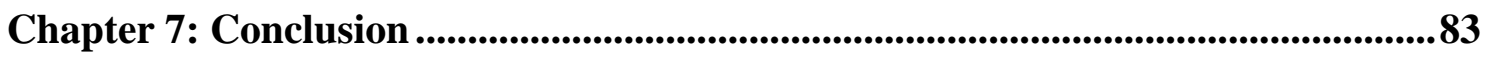

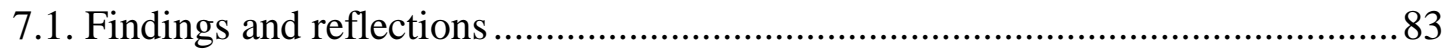

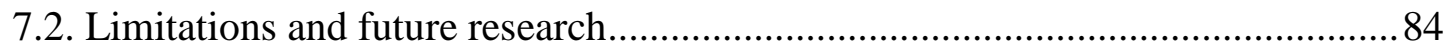

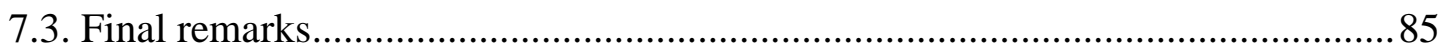

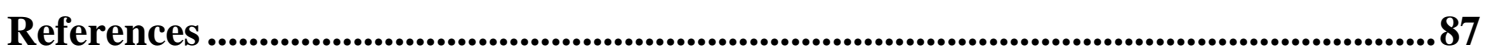

Appendix 1: Human ethics approval................................................................99

Appendix 2: Supervisor's support letter ........................................................101

Appendix 3: Participant information sheet ....................................................................103

Appendix 4: Research consent form..............................................................113

Appendix 5: Interview questions ..........................................................................117

Appendix 6: Request letter for interview appointment ............................................124 


\section{List of figures}

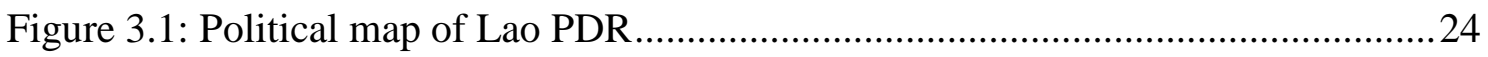

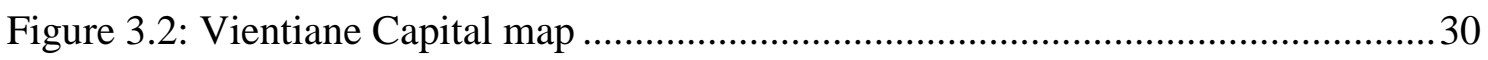

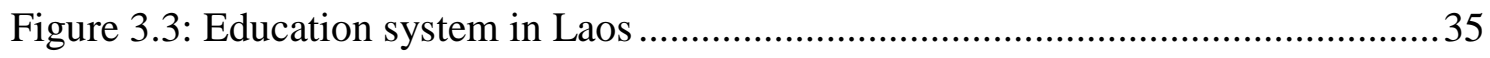

Figure 3.4: Public administration and management system for education ..................... 36

Figure 4.5: The linkages between feminist theories and research questions ................. 45

Figure 4.6: The linkage between target participants and the research questions ............51

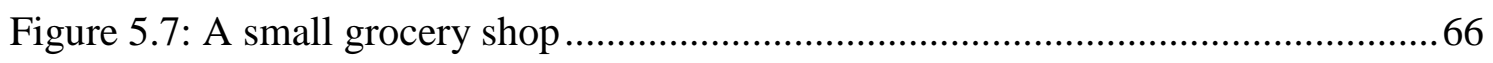

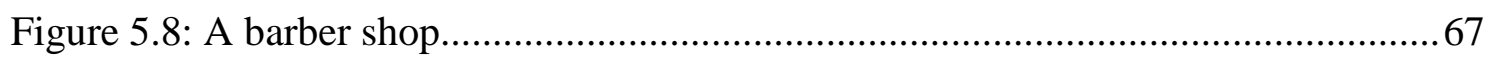

\section{List of tables}

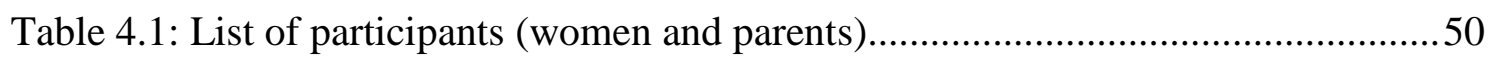

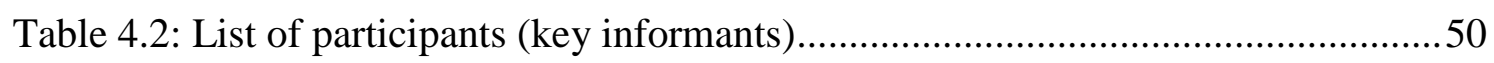




\section{List of abbreviations}

ADB

AEC

ASEAN

BOL

CU

DACUM

DoES

ECE

$\mathrm{ESDF}$

ESDP

GDP

GER

GNP

HEI

ICT

ILO

Lao PDR

LDC

LPRP

MDGs

MoES

MPI

NA

NESRS

NGPES

NUOL

PPA

SEA Games

SDGs

SKU

SU

TTC
Asian Development Bank

ASEAN Economic Community

Association of South-East Asian Nations

Bank of the Lao P.D.R

Champasak University

Developing a Curriculum

Department of Education and Sports

Early Childhood Education

Education Sector Development Framework

Education Sector Development Plan

Gross Domestic Product

Gross Enrollment Rate

Gross National Product

Higher Education Institution

International and Communication Technology

International Labour Organisation

Lao People's Democracy Republic

Least Developed Country

Lao People's Revolutionary Party

Millennium Development Goals

Ministry of Education and Sports

Ministry of Planning and Investment

National Assembly

National Education System Reform Strategy

National Growth and Poverty Eradication Strategy

National University of Laos

Participatory Poverty Assessment

Southeast Asian Games

Sustainable Development Goals

Savannakhet University

Souphanouvong University

Teacher Training Centre 
TVET Technical and Vocational Education and Training

UN United Nations

UNCTAD United Nations Conference on Trade and Development

UNDP United Nations Development Programme

UNESCAP United Nations Economic and Social Commission for Asia and the Pacific

UNESCO United Nations Educational, Scientific and Cultural Organization

UNFPA United Nations Population Fund

UNICEF United Nations Children's Fund

USD United States Dollar

VUW Victoria University of Wellington

WHO World Health Organisation 


\section{Chapter 1: Introduction}

\subsection{Introduction}

Since the early 1970s, there has been more attention paid to women in development (Gupta, 2014). Gender differences and gender gaps in education are considered to be major barriers to economic growth and development. Since women provide half of the labour force and are effective in community development, eliminating gender disparities in several sectors of the economy and education not only leads to more "equality" but also higher "efficiency" (Emadzadeh, 2003). However, women still suffer from inequality by having less power and fewer opportunities than men in many parts of the world (Gupta, 2014). Recently, the rise of feminist ideas has helped inform policies and led to huge improvements in women's conditions throughout the world (ibid).

Women have made important gains in expanding their access to different levels of education in the last three decades, but they still confront substantial educational disadvantages in much of the Third World (Stromquist, 1989). In tertiary education, gender disparities are the highest; young men typically pursue tertiary education before their female peers. The cost of enrollment in tertiary education is also more expensive than at elementary or secondary level (Jacobs, 1996). When the cost of education is high, parents may decide to allow sons to continue to study, but not their daughters (Sutherland, 1988).

There is a significant gender gap in tertiary education in Laos (ADB \& World Bank, 2013). The government of Laos and international organisations have collaborated to reduce the gender gap in education (ibid). However, to encourage more women to pursue education also requires addressing other barriers, such as women's motivations and behaviors. Not only that, family characteristics and social norms should also be considered. This research focuses on women and tertiary education by examining women's individual motivations and barriers, family influences and social norms. The research uses feminist perspectives as a tool to analyse particular obstacles for women, gender issues and gender relations.

\subsection{Key issues framing the research}

Joining the ASEAN Economic Community (AEC) in December 2015 (Vilavong \& Hess, 2016) and huge economic growth has led to high demand and competition in the labour 
market in Laos (World Bank, 2016). The World Bank reported that there is insufficient labour supply and most Lao workers lack necessary skills and knowledge (ibid). There is also a high percentage of unemployment. Therefore, focusing on the development of young people to equip them with knowledge and skills in order to supply the labour market is an urgent need of the government. Improving the quality of tertiary education and increased access to higher education institutions (HEIs) are important for the development of people with knowledge and skills.

After the foundation of the country in 1975, the Government of Laos gave priority to primary education as the percentage of the population who were illiterate was very high. Until the early 1990s, higher education was strictly limited and was less of a priority (Siharath, 2010). Only two percent of the population have a higher education qualification in Laos (Laos Sūn Kānsathiti hǣng Sāt, 1997). One reason is the low priority given to higher education by the Government of Laos after 1975. The situation varies enormously across space, with more than seven percent of the population having a higher education in Vientiane Capital and less than one percent in the northern provinces (Bourdet, 2001).

Fox (2003) provides an explanation for why Lao women lack access to education in general. Women in Laos are not discriminated against by the educational institutions; rather they are restricted by cultural norms regarding gender roles and the economic requirements of working at home. Another argument is that children have to obey the directions of their elders, as respect and obedience to elders is embedded in Lao culture. Therefore, he argues that the gap in access to education is more an issue of poverty than of cultural norms. In rural areas of Laos, a lack of access to teachers and schools are major factors preventing both boys and girls from receiving a formal education. It could be argued that Fox's research did not apply feminist perspectives and therefore the main implications of gender inequality in education were not sufficiently addressed.

The research available to foreigners on Lao culture is limited, and the country has only been opened to outside researchers relatively recently. Lao scholars have done academic research, but little of this has been translated into international languages. In education the same condition prevails, with little information available or researched either by foreign or Lao scholars. In some sectors of education, the data gaps and lack of appropriate collection systems still exist. Therefore, there is a gap in the literature on women and education in Laos, especially in tertiary education. 


\subsection{Aim and objective of the research}

The main aim of this research is to explore the main barriers to women's access to tertiary education, focusing on family characteristics, women's behavior and preferences, and social norms. A feminist lens will be applied to examine and analyse the influences on women's access to tertiary education in Vientiane Capital, Laos. Feminist theory offers explanations for unequal participation of women. Using feminist theory will help me to be more aware of why families encourage men to access education and why women have to stay home and do unpaid work.

\subsection{Research questions}

The research will examine "How family characteristics, social norms and individual motivation factors influence women to access tertiary education, using a case study in Vientiane Capital, Lao PDR". Further sub-questions to answer this main topic are set out below:

\section{Sub-questions:}

1. How do family characteristics (family size, economic status and parents' education) affect women accessing tertiary education?

2. How do social norms influence women's access to tertiary education?

3. What are the main motivations of and barriers to individuals to undertaking tertiary education? Why?

\subsection{Significance of the research}

This research will provide better understanding of the situation and the importance of tertiary education in Laos. It also set out the main factors that influence women's access to tertiary education, and women's needs and aspirations to strengthen their capacity and knowledge. In short, it will provide more evidence of inequality in education in Laos, particularly tertiary education.

While there are various studies on education in Laos, there are less studies on tertiary education, especially related to women. Even though Fox studied on women and education in 2003, it was about women and education in general. This research will use a feminist lens to explore barriers to women accessing tertiary education, providing a reflection on gender, education and development in a least developed country. 


\subsection{Thesis outline}

There are seven chapters in this thesis which study and analyse information relevant to women and education. The first chapter introduces the topic of the thesis. It consists of the main issues, objectives, questions, and significance and contribution of the research.

The second chapter gathers and revises existing literature related to women and education, particularly in the Association of South-East Asian Nations (ASEAN) countries. The chapter focuses on women in various aspects such as economic development, politics and families, and then it refers to women in education. It also presents some sample barriers on women's access to tertiary education.

The third chapter presents the Lao context. This chapter aims to offer information on Laos, including on development in economics and politics, in terms of women's participation. The chapter also focuses on the education of girls and women in Laos. It also provides some information on Lao cultures.

The fourth chapter offers the methodology used in the thesis. It presents the tools and methods used to structure the thesis, to gather information in the field, and to analyse the findings, ahead of initiating writing, revising and editing. The main tool in this thesis is qualitative research, using semi-structured interviews and document reviews. The feminist theoretical framework which is applied also has mention in this chapter.

The fifth chapter reports all the main findings from the semi-structured interviews and document reviews. The main findings refer to the sub-questions, which relate to family characteristics, women's preferences and behaviours, and social influences on women and tertiary education.

The sixth chapter discusses the main barriers for women to access tertiary education. The main findings are financial hardship, an imbalance in household chores between male and female siblings, working preferences and opportunities, and tertiary enrollment and information dissemination. The main findings have been revised and compared with the existing literature and feminist theoretical frameworks. 
The last chapter presents the main conclusion of the whole thesis with the limitations of the research and recommendations on further important topics and issues for ongoing study

\subsection{Summary}

This chapter provides general information about this thesis on women's access to tertiary education in Laos. The gender gap still exists everywhere. Even though women have made progress in economic development, politics and education, they are still behind men in various respects. In building capacity of women through education it is hoped to improve women's livelihoods. Laos is experiencing ongoing development of the economy and services and there is high demand for labour. Therefore, focusing on education is important, especially tertiary education.

Therefore, study on women and access to tertiary education is important, in order to increase the number of women as well as improve the quality of women's study. I hope that the results will provide knowledge on tertiary education in Laos and women's livelihoods through utilising feminist lenses. 


\section{Chapter2: Literature review}

\subsection{Introduction}

The first section of this literature review will start with women and their current situation and consider the gender gap in various aspects - economic development, politics and family. The next section will present education's contribution to growth and development. The section will then illustrate advantages of tertiary education to development and to women in the context of the tertiary education situation in Asia. This section will also raise some obstacles to women's access to tertiary education in least developed and developing countries. The final section will mention some existing policies regarding women and tertiary education.

\subsection{The role of women in the labour market, politics, and family}

Of the world's population of nearly 7.6 billion, there are 100 females for every 102 males (UN, 2017b). Women certainly are placed as the second sex in developing countries (Buvinic, Lycette, \& McGreevey, 1984). They have been seen as less educated, have fewer opportunities for working, and often earn less income than men (ibid). Nussbaum (2000) emphasised that in many parts of the world women still lack support for the foundational functions of a good human life. They are more at risk of sexual abuse and physical violence, and they are less well-nourished and less healthy (ibid).

\subsubsection{Women and the labour market}

The contribution of female workers to the labour market has increased recently. For instance, between 1971 and 1995, in Latin America and East Asia, the percentage contribution of females in the labour market increased by 15 percent, and the gender gap narrowed in wages as well (Duflo, 2012). In an International Labour Organisation (ILO) report, the female labour market participation proportion persisted at 49.5 per cent globally, whereas the male participation proportion was dramatically higher at 76.1 percent worldwide. In short, gender disparity in labour force participation persists (2017b)

The burden of household chores can affect the amount of time women spend on outside work as most women have to engage in both productive and reproductive work. Momsen (1991) summarised, for example, that women worldwide have two jobs - outside and inside the home. They do not only earn income for a family, but they also take care of 
household chores - cooking food, collecting water and wood, and providing child care (Buvinic et al., 1984). Berniell and Sánchez-Páramo (2011) mention that women provide nearly five times as much time on child care, nearly twice as much time on household chores, and around half as much time on outside work as men do. Buvinic et al. (1984) mention that women have to work longer hours than men in the least developed and developing countries. In the Philippines, for instance, women work at home and outside the home an average of 10 hours a day (ibid). Various tasks and long hours working can affect women's ability to engage in skill improvement and education.

Females' jobs are also generally undervalued (Momsen, 1991). Entmacher (2014) states that the male portion in the high-wage workforce is larger than the proportion of their female counterparts. For example, the proportion of female workers who hold low-wage jobs has continually risen by more than six percent globally, from 2007 to 2014, even though women have made positive progress in education (ibid). In addition, female workers totally account for two-thirds of the almost 20 million labourers in low-wage jobs (ibid). In one example from Southeast Asia, DaVanzo and Lee (1978) noted that in the low-paying employment sectors, such as handicrafts, cottage industries, agriculture and small-scale marketing, jobs are mostly occupied by Malaysian women. Conversely, in management, professional or clerical positions, Malaysian women account for less than five percent (as cited in Buvinic et al., 1984). Being disproportionately young and poorlyeducated were the main features of the low-wage female workforce (Kim, 2000). Kim's study on female workers in the United States found that the education level of employees is an obvious feature in low-wage employment as well as that female workers are less likely to be paid low wages as their education levels rise (ibid).

These statistics show that gender gaps in the labour force still exist. The most studies show that the reason is that women are less likely to fully provide their time on outside work as they also have to take care of household chores. Furthermore, the work of women is often devalued. It illustrates that women hold the majority of low-wage positions. This is because most women have a low level of education.

\subsubsection{Women and politics}

Women have progressively taken a larger part in politics worldwide. The percentage of female held seats in national parliaments globally is 23 percent (World Bank, 2017). Nevertheless, only 26 countries in the world had reached the target defined by the U.N. 
Economic and Social Council in 1990 of having 30 percent or more female held national parliamentary seats (Duflo, 2012). Many countries and international organisations have concentrated on women's participation in all levels of decision-making. In the 2005 report of the United Nations on the Millennium Development Goals (MDGs), Kofi Annan, the Secretary General of the United Nations, stated: "the full participation of women to all levels of decision-making is a basic human right" (Duflo, 2012, p. 14). The decisionmaking participation of women particularly gives precedence to political participation and leadership at the international, national, regional and local levels (Rai, 2005).

Women holding more seats in politics might directly or indirectly benefit female citizens. Swamy, Knack, Lee, and Azfar (2001) and Cheng (2014) also mention that female politicians can govern differently. Duflo (2012) emphasises that "women leaders seem to better represent the needs of women" (p. 21). Female politicians, for example, are more likely to focus on problems that matter to female citizens such as children's welfare, gender balance, reproductive rights, day care and elderly care (Burrell, 1996). In addition, some evidence also demonstrates that, in various locations, influential government authorities have advocated that growing female representation on the ground will decrease the extent of corruption (Cheng, 2014; Swamy et al., 2001) These studies show that female politicians are more likely to focus on policies for women's issues and that they are less likely to commit corruption.

However, women are still under represented politically compared to their male counterparts. Female representation in parliament has been continually hindered by many factors (Duflo, 2012). The lack of previous political experience of women and having less training and education are the main barriers to greater participation of women in policy making (ibid). Verba, Schlozman, and Burns (2005) declare that "educational attainment is, in fact, the single most potent predictor of an adult's political activity" (p. 110). Dahrendorf (1965) noted many years ago that education enables people to comprehend their rights and political system and then become actively involved in political decisions and processes (as cited in Hadjar \& Schlapbach, 2008). As suggested by Kam and Palmer (2008) education is a key factor to ensure better access to participation because a good understanding of political context and a higher comprehension of societal issues helps to inform political action. Similarly, reaching a higher socio-economic position might encourage more involvement in politics and societal issues. In contrast, women will not have financial and human capital, which are important for them to represent a group of 
people or launch businesses, if they do not have access to educational and professional opportunities (Paxton \& Kunovich, 2003). In Latin America, for instance, the enlargement of the representation of women in politics has been significantly influenced by the enlargement of the education of women (Htun, 2003).

In short women's involvement and female representation in politics are progressing; however, the progress is slow and only a few countries are improving steadily. Generally speaking, poor education and lack of political experiences of women are the main obstacles to increasing the percentage of women's representation in politics.

\subsubsection{Women and family}

Family is the main social unit of every society. It represents the principle economic and social unit resting on agreed upon sexual relationships and offers social support and familiarity (Hirschman \& Loi, 1996). Within the family, women typically take nurturing roles, while men tend to be less reliant on family bearing systems than women (Buvinic et al., 1984). Parental suggestions and opinions are always to be conformed to and parents are involved in most of the decisions of women - the determination of work, and places to work (Visvanathan, Duggan, Nisonoff, \& Wiegersma, 1997). Definitely, Kung (1981, 1983) and Greenhalgh (1985) found that parents are heavily involved in the decisions regarding daughters' schooling and when they will stop education, and when and where they will become employed. Overall, women to some extent still rely on their parent's decision making on whether to stay in education or enter the workforce.

In some societies, parents tend to prefer sons over daughters - particularly when considering economic contribution to the household. This is illustrated in the study of Maertens (2013), conducted in three villages of India in 2007 and 2008, which found that, among households sampled in which there were both sons and daughters in families, $61 \%$ of the parents predicted that their sons were more likely to take care of them than their daughters. The study showed that male children were predicted to provide, on average, $78 \%$ of the household financial support during old age of the parents. The female children were conversely expected to contribute, on average, $37 \%$. The parents' preference might influence decisions on supporting care and education for female children. Parental views on the value of children can be extreme. Wolf (1972), Greenhalgh (1985: 277) and Gates (1987), for example, note that parents socialise daughters "to believe that they themselves are worthless, and that literally everything they have - their bodies, their upbringing, their 
schooling - belongs to their parents and has to be paid for" (as cited in Visvanathan et al., 1997, p. 126). While both sons and daughters are born owing their parents this debt, sons are able to contribute later by looking after elderly family members. Conversely, as many daughters leave their birth home for marriage, they have to refund their debt in early life. Therefore, spending on schooling for daughters may be seen as more 'wasted' resources for parents (Greenhalgh, 1985, p. 270). For instance, studies from Guatemala and the Philippines demonstrate that parents prefer sons up to around the age of 10 only moderately with their goods and time, but from a social point of view boys and girls are dealt with very contrastingly. Girls are more likely to spend time with younger siblings as mother-substitutes and less likely to continue in education than boys (Buvinic et al., 1984).

Most labour at home is done by girls (Terry, 2007). They normally participate in the production and/or businesses of their households (for example, farming) (Maertens, 2013) and are expected to provide the twin roles of both reproductive and productive tasks (Momsen, 1991). In every society, the great bulk of household tasks are performed by women and girls (ibid). Consequently, throughout the year, women have less time for leisure than boys as they have to take charge of typical tasks which include most of the housework and the collection of wood and water. Women also have obligations in respect of religious and social duties (ibid). The imbalanced division of labour begins in childhood (Terry, 2007). Terry demonstrates that in many countries of the Global South "it is common to see groups of young boys playing in the street, while girls are nowhere to be seen - they are indoors, helping their mothers to cook, clean and look after younger siblings" (2007, p. 10). For example, in a study in a rural area of Gambia in West Africa, interviews of teenage girls and boys found that girls have to take care of many tasks in the early morning and get up earlier than everyone else to fetch water and cook breakfast (ibid). They also have to do similar tasks in schools such as cleaning the classrooms, while the boys 'sit under a tree and watch'. After school, the girls sweep floors and wash dishes while boys play football. Due to tiredness, the girls go to bed earlier than the boys, by some two hours, then they wake up early (ibid). Moreover, in the case of some poor families, parents might send out girls for hawking every day. For instance, in Nigeria, hawking is a customary method for daughters to contribute to the family earnings. Therefore, Nigeria forms an example where girls/daughters are domestic labour and also an income earner for a family from a young age (ibid). In short, girls in Nigeria have less time for both leisure and schooling. 


\subsection{Education}

\subsubsection{Education and development}

Education brings significant benefits to economic development and society. Psacharopoulos and Woodhall (1993) mention that education is significant for the growth of economies. This is illustrated in the total rise in incomes, opening up of new occasions for social progress and decrease in the absolute level of poverty. Singapore's strong economic growth illustrates the positive relationship between education and economic development: "the relationship between education and economic growth in Singapore, has been much stronger, with the educational system and its output exhibiting a very strong and much closer linkage to the requirements of the economy" (Ashton \& Sung, 1997, p. 207). Research on Vietnam, Anwar and Nguyen (2010) also shows that investment in education and training have provided significant boosts to nationwide economic growth. Girls and women's education is also particularly important for economic development and poverty reduction. A speech by Mr. John Hendra, UN resident coordinator in Laos, noted that "there is a no greater investment in poverty reduction and development than investment in women's education" (Lao Women's Union, 2017).

Education brings social benefits. Leigh (2001), for example, writes that organisations with well-educated people tend to foster new learning and innovation. Leigh (2001) also notes that students who are less likely to deflect the attention of teachers and interrupt classes causing the teacher to focus on discipline are mostly from well-educated parents. Leigh (2001) also writes that education brings benefits to wider society, including good public health, clean environments, low crime rates, democratic processes and political stability.

Given the benefits of education, many countries give priority to education development by spending a large proportion of the national budget on it. The relationship between economic growth and educational development has taken on much significance for policy makers in Southeast Asia, throughout previous decades (Hallinger, 2010). Among the most rapidly developing countries, a core component in the national development strategies is education reform (ibid). During the 1990s, for instance, a new strategy was utilised: one of a learning society and thinking schools. This strategy obviously emphasised the link between sustainable development of the society and learning in schools (Gopinathan \& Kam, 2000). Many Southeast Asian countries are now 
implementing higher education reforms aiming to contribute strong human resources to their economies.

\subsection{Tertiary education}

In 2014 there were more than 625 million people aged between 20 and 55 years in the ASEAN area, approximately 51 percent of the total population (Gajaseni, 2015). Education is important for ASEAN citizens of working ages to ensure socio-economic advancement - that is, higher earnings and better quality of life (ibid). In short, gaining a tertiary qualification provides greater opportunities to do this. The United Nations Educational, Scientific and Cultural Organization (UNESCO) defines tertiary education as "all types of education (academic, professional, technical, artistic, pedagogical, long distance learning, etc.) provided by universities, technological institutes, teacher training colleges, etc., which are normally intended for students having completed a secondary education, and whose educational objective is the acquisition of a title, a grade, certificate, or diploma of higher education" (Songkaeo \& Yeong, 2016, p. 3). In addition, Heuser (2007) also explains more about the positive tertiary education that it is possible for students to gain through developing the cognitive capacities, skills and knowledge essential to raise the efficiency and productivity of businesses and organisation. An education of this calibre would enhance the ability of graduates to problem solve and make decisions, engage ethically and intellectually, and compete constructively in their work in different kinds of organisations - educational, political, social and economic.

The contribution of tertiary education to development is important: tertiary education, through offering a labour force with technical, managerial and professional skills, enhances the rapid economic growth of industrialisation (Tilak, 2003), and as the "engine of development in the new world economy" (Castells, 1994, p. 14). In addition, higher levels of tertiary education are significantly related to the quality of health care in a nation, as generally speaking highly educated people are more likely knowledgeable of the availability of basic healthcare services and the necessity for health care (Tilak, 2003). The relationship between higher education and fertility levels is also important. Korea and Japan, for instance, with very low birth rates, have high levels of tertiary education, 1.5 and 1.4 correspondingly (ibid). Conversely, in Cambodia and Nepal, less than one percent of the population has higher education and the birth rates are 5.3 and 4.8 respectively (ibid). Studies on higher education and development in Asia do not illustrate clearly the relationship between higher education and poverty reduction. However, Tilak 
(2003) mentions that people may get rid of poverty by having basic education; this can be confirmed by attainment in secondary and tertiary education, which assists in improving adaptability and providing greater economic chances.

\subsubsection{Higher education benefits to women}

Through tertiary education attainment, students have been able to develop their knowledge, skills and professionalism. This can lead students to be more reliable, confident and independent. As Coleman (1988, p. 116) wrote, those who spend their resources, time and effort in improving their knowledge and human capital through tertiary education are profited in numerous forms: "in the form of a higher understanding of the surrounding world - in short, all the benefits that schooling brings to a person".

The participation of women in higher education brings them greater economic independence. For example, a study on higher education and women's empowerment in Pakistan by Malik and Courtney (2011) found that the basis of economic self-reliance of women may be formed by equipping themselves with knowledge gained from tertiary education. The study results indicated that $62 \%$ of respondents stated that they have full control over their earnings (ibid):

"Nothing is more important in life than having your own money... You can achieve this only by having a good degree and then a respectable job, which would eventually improve your social status in society" (Malik \& Courtney, 2011, p. 37).

Educated women are able to greatly control their incomes. This in sequence increases their self-reliance and shapes a basis of communication and personal development. Significantly, the consequences illustrate that eventually, monetary independence of women benefits their family and particularly their children (Malik \& Courtney, 2011):

"I am so happy that I am not dependent on any man for my living and I don't intend to be.... My earnings are my own, though I spend it mostly on household needs as my husband's income is not enough and I want to give the best to my children" (Malik \& Courtney, 2011, p. 37). 
Increasing women's access to schooling will then build their capacity, due to women performing a greater role within a family and a community. Furthermore, tertiary educated women feel boosted in communicating their perspectives, they are more likely to be respected and their notions are progressively admired (Malik \& Courtney, 2011):

"A few years back, my opinion was not taken into consideration ... my parents call me when they need advice; they share their problems with me and want suggestions to resolve them. This really gives me confidence. I feel valued ... I'm not sure of the reason for this change ... but I think it's because of my education" (Malik \& Courtney, 2011, p. 38).

In short, higher education attainment provides a lot of benefits to women only does it increase their knowledge and professional skills, but it also empowers women to be more confident. With knowledge and confidence, women are more independent and more likely to generate and manage their own income. This also brings advantages to their family and their children.

\subsubsection{Tertiary education in Southeast Asia}

In Southeast Asia, it has been emphasised that tertiary education's role is to provide quality university graduates adept in the skills required for the knowledge-basedeconomy (Symaco, 2013). In 2015, there were approximately 7,400 higher education institutions in Southeast Asia - a high number, but needed to produce the skills and education levels required for a rapidly growing region (Gajaseni, 2015). However, access and equity concerns persist in every Southeast Asian nation (Songkaeo \& Yeong, 2016). The Bruneian government, as just one regional example, has acknowledged that seats at public universities are limited, so the government enhances private education to play an increasing role in serving the high demand (ibid).

However, many higher education institutions in the ASEAN region have a limited budget. In most countries, tertiary education is allocated less than one percent of Gross National Product (GNP) (Tilak, 2003). In a few developing counties such as Myanmar and Laos higher education institutions receive less than 0.2 per cent of GNP (ibid). The MDGs and Sustainable Development Goals (SDGs) also put a strong focus on basic literacy and primary education, and aid funding is directed to this rather than tertiary education. Tertiary education, generally, is funded by the government in most societies (ibid). 
However, there has been a gradual decrease in government funding on tertiary education, in recent years. Several changes are influencing this trend including the introduction of student loans, funding grants, and related cost-recovery measures, along with scholarships (Ziderman \& Albrecht, 1995). Presently, various universities are making several innovations in the mobilisation of non-governmental funding as both public and private universities are also needing to generate resources by themselves (Tilak, 2001). As a result, most public and private universities generate resources from enrollment fees and school services. It is in turn a burden for students to be responsible for enrollment fees and school services.

Tertiary education situations and systems differ across the 10 member nations of ASEAN depending on the levels of economic growth, geographical sub-region, population, and religions and cultures. Levels of economic growth are likely to influence the situation and quality of education. For instance, Laos, Vietnam, Cambodia and Myanmar are on the list of low-income countries. The present situations of tertiary education in these countries are of high demand in terms of enrollment requirements, but limitations of resources to support this demand, lack of relevance of institutions in light of the changing requirements of the knowledge economy, and a lack of skilled faculty and staff (Gajaseni, 2015). On access to higher levels of education, the requirements for entrance and the quality of secondary education both should be considered. The Cambodian government, for example, acknowledges that students need a more flexible path to enter higher education, and the secondary schooling curriculum should provide fundamental knowledge for students to enter a higher education institution (ADB, 2012).

In some countries of Southeast Asia, the management of higher education seems to be deficient (Tilak, 2003). Tilak's study, for example, noted that the management of the education system in Vietnam was broadly recognized to be deficient in the late 1990s/early 2000s (2003). The management of the tertiary education system was recognised to be poor, even in respect of high level official policy documents: remarking the shortage of a single point of authority and that in most district and provincial offices authorities were insufficiently trained for the roles they take charge of (Symaco, 2013). However, while there are some existing regional studies on higher education investment and management and a few focused on learning and teaching quality, it seems there is limited research relating to social and cultural impacts of tertiary education. 
An exception from outside of Southeast Asia is entitled "Is equal access to higher education in South Asia and sub-Saharan Africa achievable by 2030?" by Ilie and Rose (2016). This study provides some information on women's access to tertiary education in South Asia and sub-Saharan Africa. The research found that the number of women enrolled in tertiary education in the two regions was less than men. Young men are less likely to attend tertiary education than young women, globally (ibid). Despite this fact, in sub-Saharan Africa and South Asia, this model is in contrast: for every 100 enrolled young men in South Asia, there are 81 young women; while for every 100 enrolled young men in sub-Saharan Africa, there are only 64 young women (UNESCO, 2015). The report of UNESCO on "Global Monitoring Report 2015: Education for All 2000-2015: Achievements and challenges" also noted that in these countries, the poorest were least likely to get access to higher education (ibid). The report also mentions that gender gaps are reinforced by wealth gaps: the poorest young women are most likely to be excluded from tertiary education (ibid). In short, in tertiary education gender disparities are high young men typically pursue tertiary education before their female peers. It is also notable that the cost of enrollment in tertiary education is also more expensive than enrollment at elementary or secondary level (Jacobs, 1996). When the cost of education is high parents may decide to allow sons to continue to study, but not their daughters (Sutherland, 1988).

\subsubsection{Women and access to education}

For both males and females, participation in education is highest at primary, lower at secondary, and lowest at tertiary levels (Stromquist, 1989). The number of male students in the school system is higher than female students, and the gap rises in the higher levels of education (Buvinic et al., 1984). However, optimistically, there has been positive progress in gender equality, as cross-the-board enlargement of educational opportunities has been achieved, especially where female disadvantage was more prominent (UNESCAP, 2014). For example, in South and Southwest Asia, there has been an increase in the gender parity index for the net enrollment rate in primary education, from 0.84 in 2000 to 1.0 in 2012, illustrating the development in just over a decade in educational opportunities for girls (ibid).

In some countries, gender disparity remains a challenge, despite general improvements across the region (UNESCAP, 2014). For example, in Pakistan there were 74 girls to every 100 boys in secondary school, in Laos 92 girls to every 100 boys, and in Iran 95 girls to every 100 boys. These statistics illustrate the necessity to develop the 
opportunities for educating girls in these nations (ibid). McCowan (2007, p. 582) notes that "there must be sufficient places so that all members of society who so desire, and who have a minimum level of preparation, can participate in higher education'. A number of studies on women and tertiary education found that wage and employment discrimination, cultural and religious values, household financial status, parental aspirations for children, distance to school, and various other school factors influence access to tertiary education of girls (King \& Hill, 1993; Jacobs, 1996) - some of these are elaborated on below.

\subsubsection{Limitations of the number of schools}

Tertiary institutions being located far from students' place of home residence might impact on decision-making regarding women and tertiary education. As most tertiary education institutions in Southeast Asia are located in a town or a big city, it is inevitable that many who want to study will have to be away from their hometown. This might create parental worries about girls' safety and the loss of daughter's time for household chores. Beckett and O'Connell (1976), for example, conducted a survey of all female students in a northern Nigerian University and found that parents of Muslim girls were "afraid that education would spoil them" and that as many as $90 \%$ of the girls reported pressure to marry young.

School attendance might also be disrupted by poor road conditions and bad weather (Symaco, 2013). For example in rural areas of Vietnam, young people, particularly girls, may be needed to spend time assisting at home rather than spend time on study and travel (ibid). In the countryside, parents are perhaps less conscious of the importance of more education for their children, and they are definitely less likely to be generating high incomes (UNICEF, 2010).

\subsubsection{Social norms}

\section{Social norms impact on wage discrimination}

Wage discrimination in employment might be another obstacle for women's access to higher education. For example, research about women's education in developing countries focusing in East Asia (King \& Hill, 1993) found that wage structures tend to favor men. The study showed that, in 1985, women in South Korea earned less than half of what men earned, in Singapore about two-thirds, and in Hong Kong around threequarters (ibid). Men are more valued than women, in accordance with the traditional 
division of labour in the household. Because women normally participate in household tasks and/or the household businesses, they need less official education, while men are recognised as the most essential earners (Maertens, 2013). As long as bias exists, women are less keen to contest than men for employment and in the promotion period (Babcock $\&$ Laschever, 2003). These male-female wage ratios influence parents' traditional bias against educating their daughters and also discourage the daughters themselves (Maertens, 2013; Sutherland, 1988). When unemployment becomes widespread, a widely held view is that "women should withdraw into their homes and leave the available posts for men; men are seen as the breadwinners, leaving women as earners of supplementary income" (Sutherland, 1988, p. 486). Given the pervasiveness of such attitudes, women have less motivation to pursue careers.

\section{Restrictive cultures}

Restrictive cultures can also hinder women's access to education. Jacobs (1996) states, for example, that the requirement that boys and girls join separate schools can decrease access for girls in some traditional Muslim societies. The study on higher education and women's empowerment in Pakistan by Malik and Courtney (2011) also illustrates that women in Pakistan are subject to an array of psychological and social hindrances that limit their progress and lessen their ability to use opportunities to improve their abilities. In addition, Haque (2005) demonstrates how societal models in Pakistan have power over women's social mobilities to a very huge extent. For example, women lack both the confidence and the expertise to put themselves forward encourage themselves in a social situation where they would have chances to learn and improve their skills as they have normally been subject to limitations throughout their rearing. Malik and Courtney (2011) noted that women in Pakistan have to obey restrictive cultures and that parents are also strict with daughters on respect for culture.

\section{Gender bias in decision-making}

Decision-making around women's roles and girls' access to education might be made by others. For example, the study on higher education and women's empowerment in Pakistan found that women's lives are governed by family for the most part of their lives (Malik \& Courtney, 2011). Husbands and in-laws decide matters on women's behalf and take over all the controls after marriage, as well as all significant situations were also decided by their fathers, when they were young. In short, in the family, the male members take charge of the female members' life, including their marriage, education and 
profession. Furthermore, males may also take control of how many children a woman should have in some cases (ibid). With regards to higher education, $51 \%$ of students cited that they have to gain the approval of their family to study in tertiary education. Furthermore, the details of the interviews also illustrate that other family members also always participate in other decisions of women such as subjects to study, kind of university and place to stay during student life in a university (ibid).

\section{Household characteristics}

Household characteristics, such as family size, parents' education and occupation, and the household's economic conditions, are some of the main influences of women's access to tertiary education in developing countries (King \& Hill, 1993).

Family size has an impact on the time consumed on household chores by girls and women (Momsen, 1991). The burden of women's responsibilities is influenced to a large degree by the size and character of the household (ibid). Most men have more free time and work shorter hours than women (ibid). Families with many small children demand much time of women in childcare. If there are older siblings who are able to help the mother, she may not want them to do so if it means stopping their chance to participate in schooling (ibid). According to King and Hill (1993) women receive less individual attention and resources from parents when they are in large families than when they are in small families. In addition, large families might not be able to support all of their children to attend school.

Parents' occupation is also proven to be a main factor in their children's educational attainment, especially for girls. The higher parents' occupations are ranked, the greater the likelihood that their daughters will go to school (Hermalin, Seltzer, \& Lin, 1982). Hermalin et al. (1982) conclude that females whose fathers had white-collar jobs tend to have significantly more schooling than those whose fathers had blue-collar jobs. As a more specific example, in both the Philippines and Indonesia, children of farmers have much less education than others. The below quote from China highlights the situation:

“When I grow up I'd like to get a good job but I don't think we'll be able to because we're very poor. My parents have to pay more than 2000 yuan a year for my brother to go to middle school. My grandfather is the village leader, but they 
won't be able to afford to pay for me to go too. They'd like both of us to go, but they can't afford it. They can only afford to pay for one" (Terry, 2007, p. 109).

\subsection{The international agenda for higher education and women's empowerment}

Amongst the main goals of the United Nations (UN) and other humanitarian organisations are gender equality and women's empowerment (Malik \& Courtney, 2011). The issues relating to women's empowerment and gender equality have been discussed within international dialogue such as the Beijing Declaration and Platform for Action (UN, 1996), the United Nations' Millennium Declaration (UN, 2000) and the subsequently formulated MDGs (UN, 2001; UNDP, 2008; World Bank, 2003). The UN made a decision on the narrower target on MDG3 as "Eliminating gender disparity in primary and secondary education preferably by 2005 and in all levels of education no later than 2015". This was due to MDG3 being so difficult and broad as it was to "promote gender equality and empower women" (Terry, 2007, p. 6). Following its absence from the Education for All framework and Millennium Development Goals, the post-2015 SDGs consist of a particular goal in respect of tertiary education, namely that: " by 2030 ensure equal access for all women and men to affordable quality technical, vocational and tertiary education, including university"' (Ilie \& Rose, 2016, p. 436; UN, 2015).

Gajaseni (2015) has considered the ASEAN tertiary education situation from the report of the ASEAN 2015 Higher Education Forum. He has noted that there will be highly qualified human resources in the future ASEAN community. The tertiary education institutions will perform a meaningful role equipping young male and female students with "good heads" (analytical, critical, creative, decisive skills), "big hearts" (ethical and moral minded), and "skillful hands" (technical skills) (p. 9). Low/low middle income countries such as Vietnam, Cambodia and Myanmar are focusing on increasing student enrollment, system enlargement, policy reform, infrastructure improvement, and quality guarantee implementation and development (Gajaseni, 2015). Overall, it appears that most education policy in Southeast Asia is general in nature, or if gender-focused, about access to education in general. Very little policy in Southeast Asia is focused on women's access to tertiary education.

\subsection{Summary}

This chapter explained the current situation of women regarding education and specifically tertiary education. In short, a gender gap still exists. Enhancing women's 
educational attainment, including in higher education, is important for gender gap reduction. However, some higher education institutions still face issues of limited budget, insufficient staff and facilities and outdated curriculum - especially in higher education in Southeast Asia. This chapter also highlighted the obstacles women encounter when looking to access education - including financial status, family characteristics, and social norms. However, there is limited regional and Laotian research on women's motivation and behavior regarding higher education as well as on women's access to tertiary education. The next section of this thesis will introduce the Laos context of the research - including education, women, and culture in Laos. 


\section{Chapter 3: Economic development, education and women in Laos}

\subsection{Introduction}

This chapter will focus on the Lao context, including economic development, education and women. The chapter starts with a profile of Laos, including the development situation, women and economic development, society and cultures, politics, and a Vientiane profile. The next section will explain education in Laos, initiating with an education profile, and continuing with an overview of the education system, education management, gender in education, and women and education policies. The last section will mention the current situation of tertiary education in Laos.

\subsection{Lao profile}

Laos is a small country, located in Southeast Asia, surrounded by five neighbouring countries: China, Myanmar, Thailand, Vietnam, and Cambodia (Lao Statistics Bureau, 2016). The total area of the country is 236,800 square kilometres (WHO, 2014) and threequarters of the country is plateau and mountains. The poverty rate in these areas is still high, as social services, including health and education, are more challenging to provide (MPI \& UNDP, 2009). Improving infrastructure and road construction to access rural areas is a key goal of the Government of Laos in reducing poverty (Lao Statistics Bureau, 2016). At present, less than 60 percent of rural dwellers have access to roads (ibid). 
Figure 3.1: Political map of Lao PDR

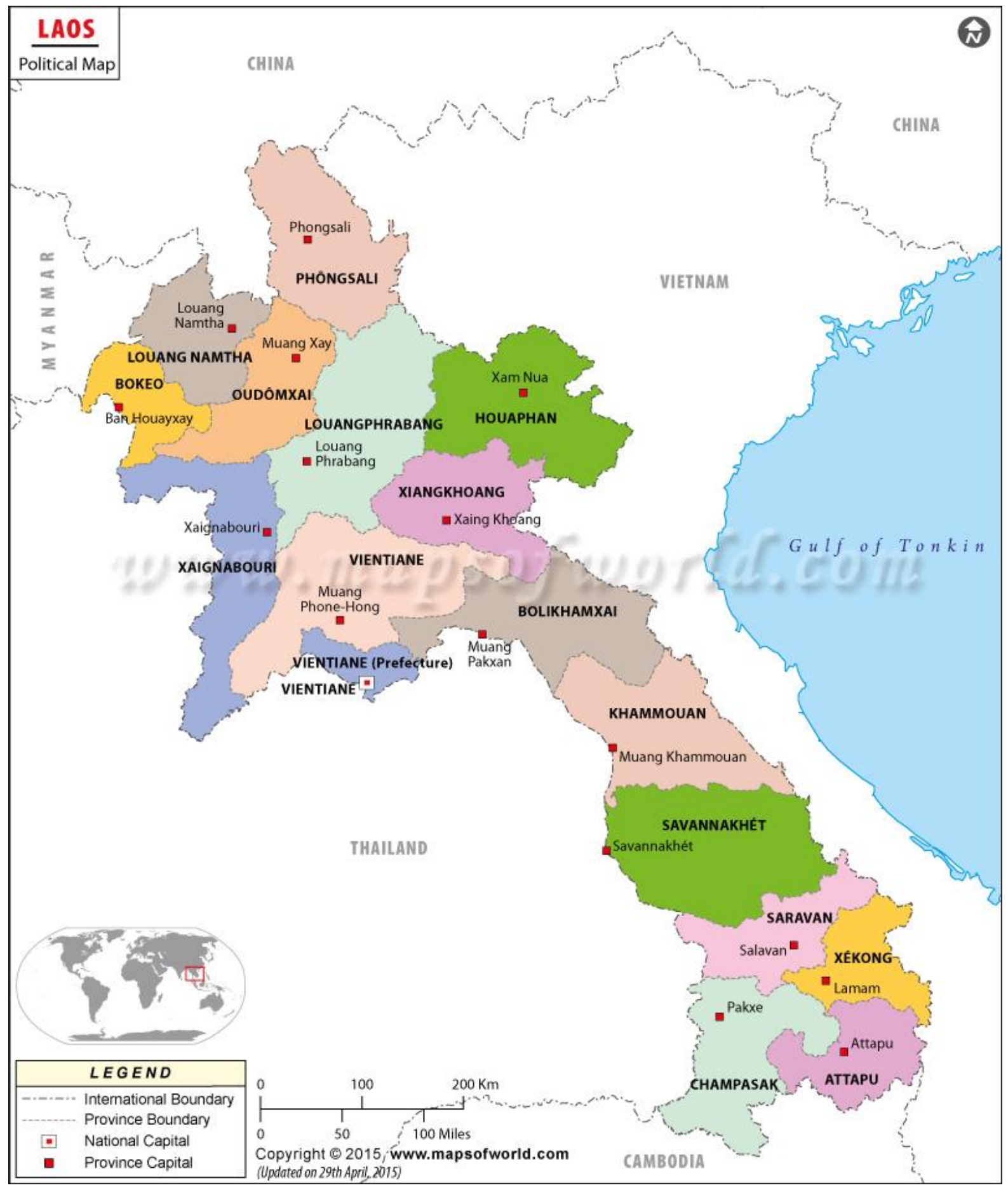

Source: Map of world website (2015) 


\subsubsection{Development situation}

Laos is officially a Least Developed Countries (LDC), ranking 21 among the 47 Least Developed Countries around the world (UNCTAD, 2017). Poverty still remains, although the rate has slightly decreased from 27.6 percent to 23.2 percent from 2008 to 2013 (UNDP, 2017a). The poverty rate is higher in rural areas than in urban areas because of the poor access to economic opportunities in the rural areas (World Bank, 2012). Currently, Lao economic development is making satisfactory progress. In 2016, the gross domestic product (GDP) per capita reached US\$2,408. The share of GDP by major sector consisted of 44 percent in services, 37 percent in industry, and 17 percent in agriculture (Lao Statistics Bureau, 2017). The GDP growth rate was seven percent (ibid). The Government of Laos has a long-term overarching goal to graduate from the list of LDCs by 2020 . It is hoped that this goal will be achieved with conservation of the country's politics, economy, society and cultures (Phetsiriseng, 2009).

Lao economic growth over the last decade has been among the fastest in Southeast Asia (ADB, 2017). However, the growth seems not to benefit the poor as the growth comes from industrial activities such as mining and hydropower (Soukkaseum, 2017). These activities create few jobs for the poor, unlike the agricultural and fisheries sectors (ADB, 2017). The share of the agricultural and fisheries sectors in GDP, the main activities of the Lao population, especially for the rural residents, are still important although they have started to shift. In 2005, the percentage of the employed population in agriculture and fisheries was $76.6 \%$, services and trade was $15.6 \%$ and construction and industry was just 7.7\%, according to the official estimates of Lao Labour Market Indicators 2001-2003 (Phetsiriseng, 2009). Additionally, the Lao Labour Market Indicators 2001-2003 reported that the percentage of the employed population in self-employment was at $56 \%$, and in unpaid family work was $26 \%$ (Onphanhdala \& Suruga, 2006). Therefore, the majority of the Lao population are farmers, self-employed and unpaid workers. They seem less involved in industries and services sectors that demand educated and skilled labour.

Lao has the youngest population compared to other ASEAN countries, with the population aged 14 years or younger accounting for 32 percent. On the other hand, 64 percent of the total population is at working age (aged 15-64) (ILO, 2017a). The total Lao population is estimated to rise by 38 percent, from 6.4 million to 7.8 million, between 2010 to 2030 (ibid). In addition, in the following decade, it is projected that there will be around 96,000 young people added to the workforce every year (ibid). The Government 
of Laos is focused on how to enhance these young men and women to be better prepared with the applicable skills and knowledge to provide full benefits to the country's development (ibid). Thus, education is a key tool to encourage the young generation to be equipped with more knowledge and skills.

\subsubsection{Women and economic development}

In Lao society, Lao women are customarily responsible for rice milling, weaving, handicraft production and small-scale trading (ADB, 2004). Females commonly are at the lower rungs of the labour market (UNDP, 2015). The United Nations Development Programme (UNDP), for example, reports that women represent 64 percent of the elementary occupations including in the services, shops, and market sales workers (2015). Women have a limited industrial role, in the management of agricultural contributions and capital, even though they represent the majority of workers in the agricultural sector (ibid). Moreover, only 23 percent of employers are women. Their businesses are often small and medium enterprises (ibid). Women represent 65 percent of unpaid workers for the family (ibid). For example, females are typically involved in various tasks and also often start working at an early age (ibid). UNDP (2015) reports that females spend four times more time than males on housework each day (female 2.6 hours and male 0.6 hours). Conversely, men are the majority of professionals, senior government officials and holders of senior positions in other sectors (ibid). Furthermore, average wages for women are nearly two times lower than for men (ADB, 2004). It is believed that the low share of women in waged employment compared to men is linked to poorer education levels (UNDP, 2015). In summary, women equally share working, but their conditions of working and payment are lower than men.

Wage rates significantly influence the life choices and work of the young generation of Laos (ADB, 2004). Young Lao females can earn a large amount of money from working in nightclubs or beer shops compared to working in a garment factory, although working in night clubs or beer shops brings a high risk of involvement in commercial sex (ibid). Furthermore, many young Lao women decide to migrate to Thailand for work due to the low salaries and limited job opportunities in Laos (ibid). Overall, there are more female than male migrants to Thailand (Phetsiriseng, 2009). Most of the migrants end up with working in small factories, domestic services and brothels where the conditions of working are often exploitative and harsh (ADB, 2004). In 2004, Phetsiriseng (2009) reported that the number of registered Lao migrants in Thailand was around 181,500 
people (with around 100,500 female). In Thailand most Lao migrants work in domestic services (21 percent), agriculture and livestock (20.5 percent), and construction (13 percent) (ibid). Overall, the majority of Lao migrants in Thailand work as labourers, and in other low wage jobs with poor working conditions.

\subsubsection{Society and cultures}

The Lao population was around 6.86 million in 2017 (World Population Review, 2017). Laos is one of the most ethnically diverse countries in the world (Fox, 2003). The country consists of 49 ethnic groups (Phetsiriseng, 2009). It is divided into four main groups according to similarity of languages used such as Lao-Tai, Mon-Khmer, Sino-Tibetan, and Hmong-Lu Mien (ibid). Lao-Tai is formed of 8 ethnic groups, Mon-Khmer is formed of 32 ethnic groups, Sino-Tibetan is formed of 7 ethnic groups, Hmong-Lu Mien is formed of 2 ethnic groups (ibid). The Lao-Tai ethno-linguistic group is the largest group in Laos, and represents $66.2 \%$ of the total national population (ibid). The Lao-Tai language, given their dominance, became the Lao official language in 1953 (Enfield, 2006). This language has been used in main economic activities, administration and education.

Laos officially has freedom of religion, meaning all citizens have freedom to believe in any religion (Ngaosyvathn, 1990). Buddhism, Christianity, Islam and the Bahai Faith are the four religions that are officially recognised by the Government of Laos (Department of State, 2015), although Buddhism has the most influence in Lao culture (Dana, 1995). According to the Lao annals, Buddhism has been presented in Laos since the Tenth Century, turning into an official religion in the Fourteenth Century. Although Buddhism is no longer the sole national religion, since 1975 (Ngaosyvathn, 1990) it is generally recognised as the national religion of Laos, especially as the dominant Lao-Tai are followers of Buddhism. In order to entirely assimilate to the country's unity, most Lao citizens are expected to follow the dominant religion (Phetsiriseng, 2009).

Buddhism has played a significant role in the situation of Lao society and in assuring the continuity of Lao culture (Stuart-Fox \& Bucknell, 1982). Buddhist monasteries (wats) and monks are located in almost every village/community, for instance (Dana, 1995). In the past, wats used to be the only schools in Lao society. Thus, most males were expected to be monks at some period of their life (ibid), and study accordingly. In contrast, women did not have a chance either to be a nun or study at a wat (ibid). In the past women were 
excluded from Buddhist monastic life. This emphasises that women were placed lower than men (Ngaosyvathn, 1993). Furthermore, traditional beliefs made the position of women difficult as society at large claimed that women represented notions of frailty and submission (ibid). The undertaking of hard work (inside and outside home), and the customs of marriage and courtship, also combined to decrease women's status in society (ibid).

Laos has one of the top rates of early marriage in the ASEAN region (UNDP, 2015). For example, women marrying before the age of 18 covered one third of the total female population (ibid). Early pregnancy is a regular consequence from early marriage (ibid). Both adolescent birth and early marriage can have a negative effect on livelihood, wellbeing and educational opportunities for women (ibid). One reason for early marriage might link to parents' decisions. As Krulfeld (1994) claims, mothers still have a significant decision making role on their children's marriage. In Laos, traditionally, daughters would live at home or close to their mothers, even after marriage, as daughters would be responsible for their parents when their parents get old. Still, mothers have significant influence on their children's decisions (ibid), particularly around their daughter's livelihood and marriage decisions.

\subsubsection{Politics}

Laos is directed by a Party Congress and led by one party, the Lao People's Revolutionary Party (LPRP) (Ogawa, 2009). The head of state is the President of Laos, who is elected by a minimum of two thirds of the National Assembly (NA). The NA consists of 40 to 50 members of the legislative body (ibid). The country consists of the capital, Vientiane, and 17 provinces. There are 145 districts and 8,507 villages (Lao Statistics Bureau, 2016). The administrative structure of Lao PDR is leveled into four divisions: central, provincial, district and village levels respectively (Phetsiriseng, 2009). The administration of the municipality provincial and district levels are managed by governors at each level, and at the village level by the village chief/head (ibid). Even though Article Two of the Constitution states that "the state of the Lao People's Democratic Republic is a People's Democratic State. All powers are of the people, by the people and for the interests of the multi-ethnic people of all strata in society..." (Lao PDR, 1991, p. 2), the administration of government still applies a top-down approach with all executive control persisting with central government from national to provincial, district, and village levels respectively (SaengOuthay, 2015). 
Laos has one of the highest proportion of women in national parliament in the region (UNDP, 2017b); almost 27 percent in 2016 (World Bank, 2017). However, within the government, the proportion of females in other decision-making roles is still low at only five percent in 2012 (UNDP, 2015). Very few women hold senior positions in national, provincial, and district offices (ADB, 2004). In 2000, only around 34,000 out of around 90,000 civil servants were women, and women formed only 1.6 percent of village deputy chiefs and 1.2 percent of village chiefs (ibid). Women seem to be represented in committees and organisations dealing with cultural and social issues, while dealing security, legal and economic issues are mostly men's responsibilities (ibid). As a participatory poverty assessment (PPA) survey conducted in 2000 with support from Asian Development Bank (ADB) found, men are the key decision makers, even though women have some involvement in family and community decision making (ibid). Overall, the number of Lao women in parliament reaches the government goal, but the participation in other leadership levels has been making slow progress.

\subsubsection{Vientiane capital profile}

Vientiane is located in the middle of the country on the left bank of the Mekong River and it covers an area of approximately 3,583 square kilometres (Sharifi, Chiba, Okamoto, Yokoyama, \& Murayama, 2014). Its total population is about 783,000 in 2017 (World Population Review, 2017). Vientiane is governed by the Mayor of the Capital, who holds the rank of provincial governor and is appointed by the President (Rafiqui \& Gentile, 2009). Vientiane consists of nine districts and district chiefs govern each district (ibid). There are nearly 499 villages within the administration of Vientiane (ibid). 


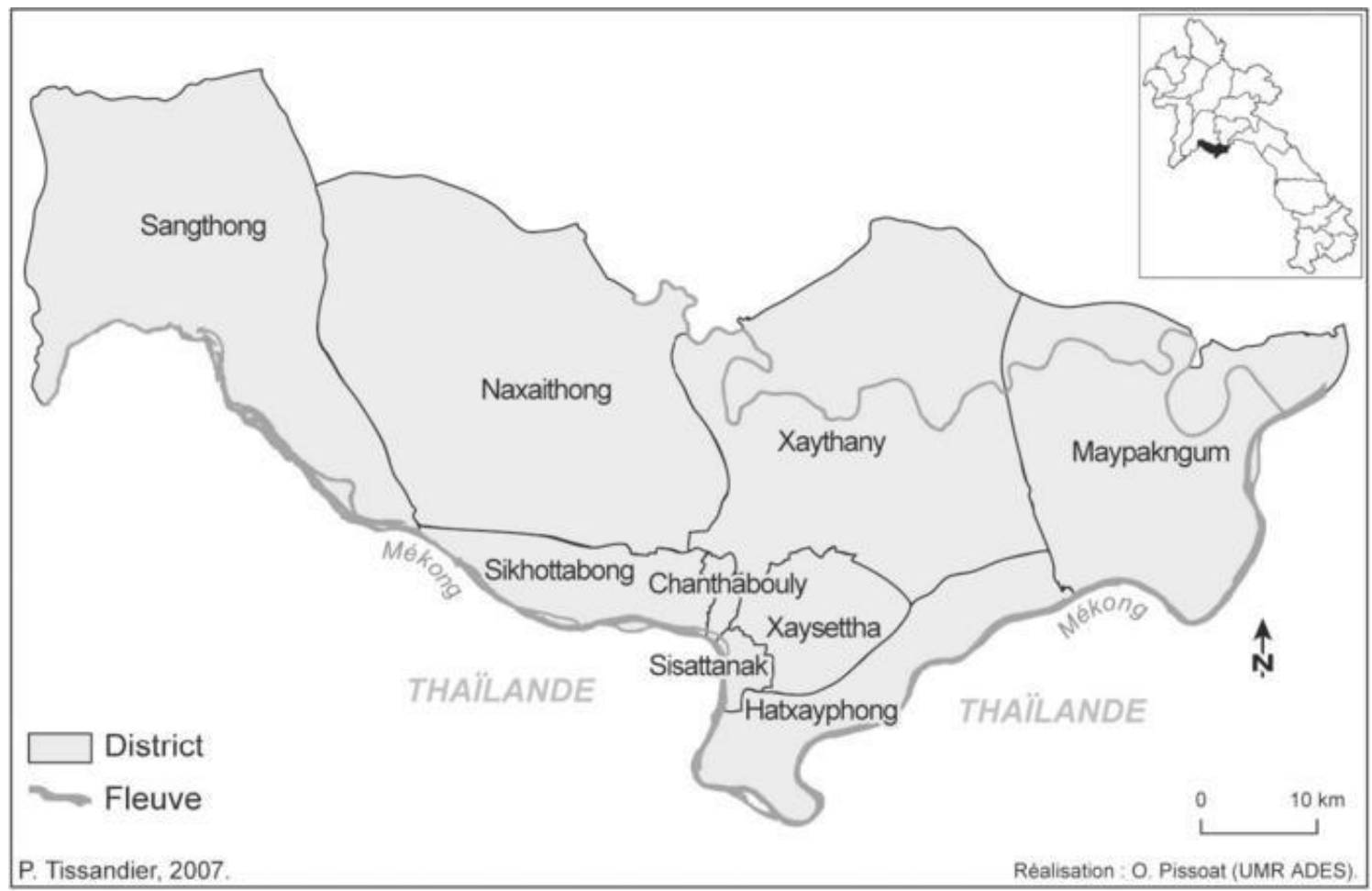

Source: Carin Info International Edition (2010)

The level of development and business activity in Vientiane is far greater than other provinces because it is the centre of economy, politics and culture of the country (Onphanhdala \& Suruga, 2006). Over the past two decades, Vientiane has benefited from what has been called "the golden era of economic and social movements of Laos" (Vongpraseuth \& Choi, 2015, p. 792). This is because many international events have been held that have brought various new changes in the capital. For instance, the Tenth ASEAN Summit in 2004; the Southeast Asian Games (SEA Games) in 2009; the great celebrations of the 450th anniversary of Vientiane in 2010; the Asia and Europe Meeting (ASEM) in 2012; and the 2015 ASEAN Economic Community (AEC Summit) (ibid). These major events have enhanced the development of Vientiane in many respects. Vientiane's growth has been reflected in the dramatic increase in GDP per capita of Vientiane from US\$135 to US\$1,320 from 1986 to 2011 (ibid). Vientiane has the biggest labour market within Laos (ibid). Migration from other provinces to Vientiane has been high, with around 51,000 migrants arriving between 2005 and 2015 (Lao Statistics Bureau, 2016). Competition for jobs is high. Consequently, a person with a better educational background and more experience is more likely to get a better job in an international organisation and in a private enterprise (Onphanhdala \& Suruga, 2006). Contrastingly, poorly educated people seem to be far from getting better job 
opportunities. Thus, a higher education level seems to open more chances for people in Vientiane to gain a better job and a good pay.

\subsection{Education in Laos}

\subsubsection{Laos education profile}

Human development and education development are the keys in the national socioeconomic development plans of the Government of Laos to graduate from the list of Least Developed Countries by 2020 (MoES, 2015). The Ministry of Education and Sports (MoES) has also planned the general target for the Education Sector Development Plan (ESDP) 2016-2020 as follows: "The Education and Sports Sector in Lao PDR is appropriately structured and resourced to create opportunity for all Lao citizens to have equitable access to quality education and sports and to benefit from socio-economic development in order for the Lao PDR to be eligible to graduate from least developed country status by 2020" (MoES, 2015, p. 8). The plan emphasised equitable access to quality education for all people in Laos. There are also many other policies and planning documents aiming to improve the quality of and access to basic education and to support employment and income-generation, including the National Growth and Poverty Eradication Strategy (NGPES), Education for All - National Plan for Action 2003-2015, National Education System Reform Strategy 2006-2015 (NESRS), Education for All Mid-Decade Assessment (October 2008), and Teacher Education Strategy 2006-2015 (ibid).

While education development is in progress, disparities of wealth, gender, and ethnicity still impact on the distribution of education services (SaengOuthay, 2015). The dropout rate persists in every level of education, and increases at the higher levels. For instance, in 2014 the completion rate of Grade 5 remained low at approximately 78 percent while the net enrollment proportion in primary education is almost 100 percent. In addition, the gross enrollment rate is higher than the gross graduation rate in secondary education (UNDP, 2017b). Additionally, insufficient and incomplete schools, low quality of learning and teaching, the direct and opportunity costs of schooling for families, and deficient funding into school quality investment are causes of low education enrollment (ibid). Hence, there are many barriers that the government has to reduce in order to achieve the education policy goals. 


\subsubsection{Education system}

The education system of Laos is composed of four education levels: pre-school (crèche and kindergarten); primary and secondary schooling including primary education (five years), lower secondary education (four years), and upper secondary education (three years); technical and vocational education and training; and higher education (Dorner \& Gorman, 2011; Lao PDR, 2007).

\section{Early childhood education (ECE) (first education level)}

From 2011 to 2015 there has been a great improvement in ECE as a consequence of applying the policy on extending access to education through pre-primary and community-based school readiness programmes with the encouragement of development partners (MoES, 2015). The numbers of school children, classrooms and teachers have increased. Meeting targets, in 2015, 66 percent of five-year-old children were in ECE, and 43 percent of 3 to 5 year olds were enrolled (ibid). However, the quality of learning and teaching in rural areas has not been taken into consideration as it is shown that preschools have not yet expanded to the rural areas of many provinces (ibid). The limitation of learning facilities, insufficient teachers, and lack of community and other stakeholders' contribution to ECE are the main causes of the slow expansion of preschools in some rural areas (ibid).

\section{Primary education (second education level)}

Primary education is acknowledged as the most significant education level in Laos (MoES, 2011). A Prime Minister's Decree stated "primary education is the first level of general education, and includes 5 years of schooling. It establishes the basic educational level that should be attained by all Lao citizens" (MoES, 2011; Phetsiriseng, 2009, p. 269). In the academic year 2014 to 2015, the registration rate of primary education has satisfactorily risen compared to the past five years (MoES, 2015). In contrast, the high repetition and dropout rates still persist, particularly in Grades 1 and 2. However, in 2014 to 2015 , there was reduction of the repetition rate in Grade 1 . The reduction was around two to three percent; still far away from target plans (ibid).

The quality of teachers in primary school remains low. Nearly half of primary school teachers do not meet qualification requirements (SaengOuthay, 2015). For instance, the Education for All mid-decade assessment report, by the MoES in 2008, found that 35 percent of primary school teachers have limited training, while 11.6 percent have no 
training attainment at all (MoES, 2008a). Primary education is free of charge, as mentioned in the reviewed Education Law in 2008 (MoES, 2008b); however, it seems to vary in practice as many school administrators continually request so-called cash support from students for school maintenance (SaengOuthay, 2015).

\section{Secondary education (second education level)}

In Laos, there were changes in the structure of secondary schooling in 2009. It was transformed from a six year system (3 plus 3 ) to a seven year system (4 plus3), as a result of the education law revised by the National Education System Reform Strategy (NESRS) and the Education Sector Development Framework (ESDF). The lower secondary gross enrollment rate (GER) has now increased. From 2011 to 2015, the GER in lower secondary education has risen from 63 percent to 78 percent (MoES, 2015). However, in 2013, only 33.4 percent were enrolled in upper secondary education (MoES, 2013). These figures show that the transition rates from lower to upper secondary school are greatly imbalanced (SaengOuthay, 2015).

The Government of Laos and international agencies have committed to investments in infrastructure, the procurement of teaching and learning equipment, and capacity building for school staff and teachers (MoES, 2015). However, then is still the need for much more improvement alongside the increase in the number of students. Some issues in lower secondary education still persist such as overcrowding in some schools, poorly trained and insufficient teachers and school staff, and insufficient facilities (ibid). With regard to facilities in secondary schools, dormitories, libraries, laboratories, teaching-learning materials, and textbooks still need further investment (ibid). Upper secondary education also faces similar problems. In addition, the subjects related to the sciences, namely physical education, natural sciences, and international and communication technology (ICT), are limited in upper secondary education (ibid). These issues affecting secondary education combine to limit the potential of students to continue to higher levels of education.

\section{Technical and vocational education and training (third education $\underline{\text { level) }}$}

Technical and Vocational Education and Training (TVET) provides post-secondary education (SaengOuthay, 2015). TVET has been gradually developed every year with cooperation between the Government of Laos, development partners, and the private 
sector. The cooperation focuses on investment in infrastructure (MoES, 2015). In 2015, there were 145 TVET schools in Laos. These consisted of 76 private vocational educational institutions, 23 vocational education institutions under the management of the MoES, another 23 vocational education institutions under other ministries or sectors, eight colleges, six integrated technical and vocational schools, five technical and vocational schools, two integrated vocational schools, and two institutions (ibid). The enrollment rate of TVET has also risen from 20,886 (females: 7,717) to 23,248 (females: 8,848), from 2012 to 2014 (ibid).

Many factors have combined to achieve a great improvement in TVET enrollment rates. Firstly, TVET institutions have been developed in terms of infrastructure, dormitories, and learning and teaching materials, through development partners' support (MoES, 2015), resulting in more available places and facilities to receive more new students. Secondly, the tertiary education reform in 2011 has led to a decrease in the numbers enrolling in universities, with the suspension of some bachelor degrees offered by private institutions (ibid). Thirdly, scholarships for students have received more funding through development partners' support (ibid), allowing the number of scholarship students to increase.

Overall, the number of private post-secondary, and non-tertiary institutions has increased significantly. However, these new institutions are able to provide only two or three years of schooling, with few and similar programmes. Popular programmes are Business Administration, English, Hospitality and Tourism and Computer Sciences (Phommalangsy, 2013). This leads to too many graduates in the same programmes, and thus job seeking difficulties. In addition, there is a very low number of students enrolled in agricultural courses, which is much desired by the labour market and is not helped by the low number of private TVET institutions offering agricultural course (MoES, 2015).

\section{Tertiary education (fourth education level)}

The highest level of education in Laos is tertiary education. This level generally provides three-year higher diploma programmes in educational institutions or a four-year bachelor programmes in universities. Currently, Master's programmes have just started to be offered by the public universities. $\mathrm{PhD}$ programmes are new and are only provided by the National University of Laos (NUOL) (MoES, 2015). Given the very new Master's and $\mathrm{PhD}$ programmes, most Lao students still prefer to continue their postgraduate aboard 
under scholarship programmes or their own budget (Phommalangsy, 2013). The Government of Laos, with support from development partners, has worked hard at financing, governance, and strengthened management of higher education systems in order to achieve the goals of increasing equity and access (MoES, 2015). In the 2004 to 2015 academic year there were approximately 36,700 students (16,100 female students or 44 percent) in five public universities (ibid). Female participation had almost reached the Government target of 45 percent (ibid).

Figure 3.3: Education system in Laos

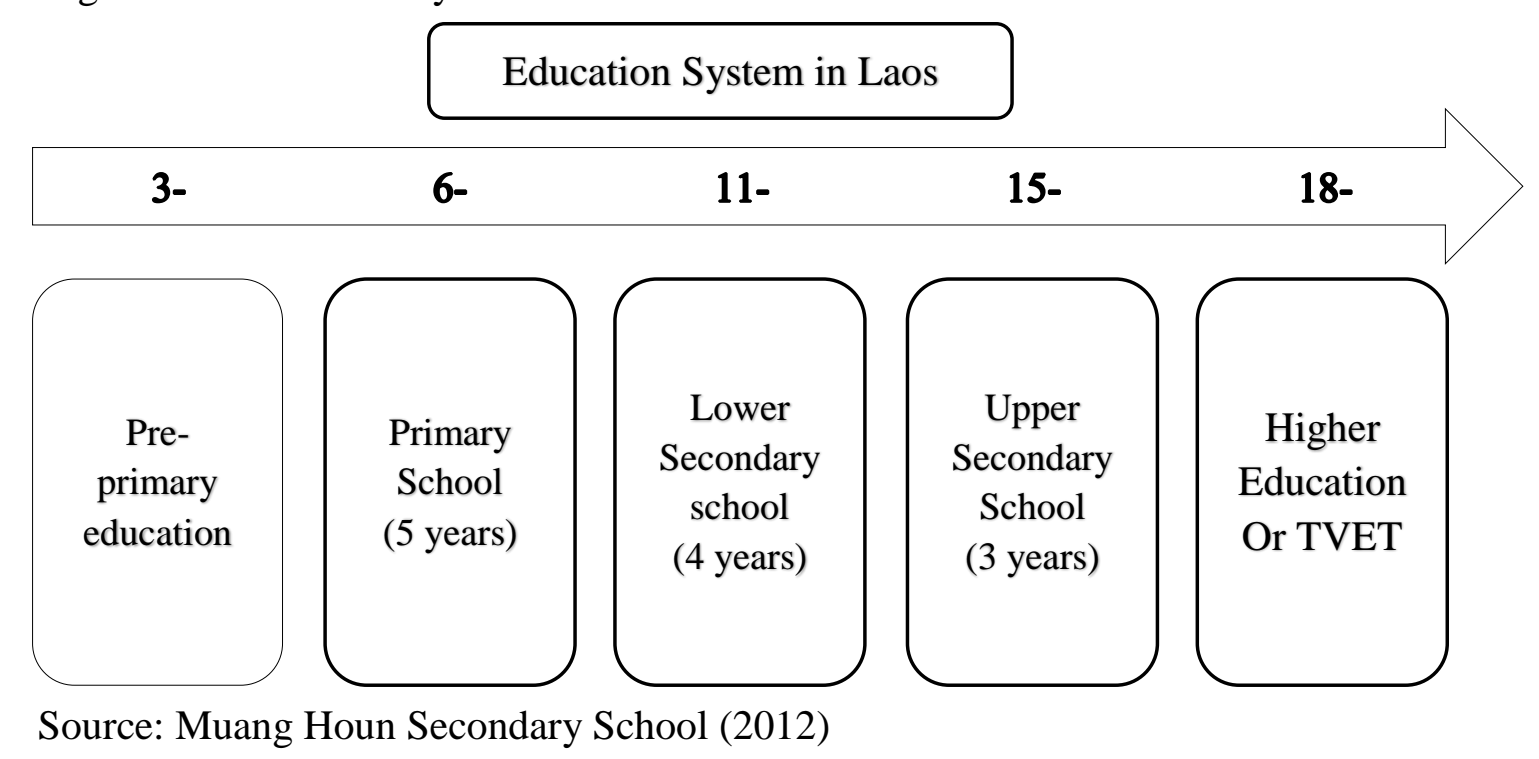

\subsubsection{Education management}

The Education Law, amended in 2008, noted that the Government of Laos has authority to control the management of education, and to hand on to MoES complete independence in administration and management of education (MoES, 2008b). The MoES is in charge of: general planning, formulation and implementation of all policies; developing curriculum; compiling and distributing teaching materials; education finance; human resource management within the education system; and the governance of all education quality for both public and private education divisions of Lao PDR (Ogawa, 2009). Overall, both public and private education, as well as formal and non-formal education, are under the responsibility of the MoES. Education management is transferred from the central to the local level. Decentralisation starts from MoES to Provincial Education and Sports Departments to District Education and Sport Bureaux respectively (ibid). 
Figure 3.4: Public administration and management system for education

\section{Ministry of Education and Sports (MoES) \\ (Central level)}

- Determines policy, guidelines, strategies, regulations, and monitoring of education

- Manages the higher education institutions, teacher training colleges, teacher training schools, technical and vocational schools, and non-formal education centers

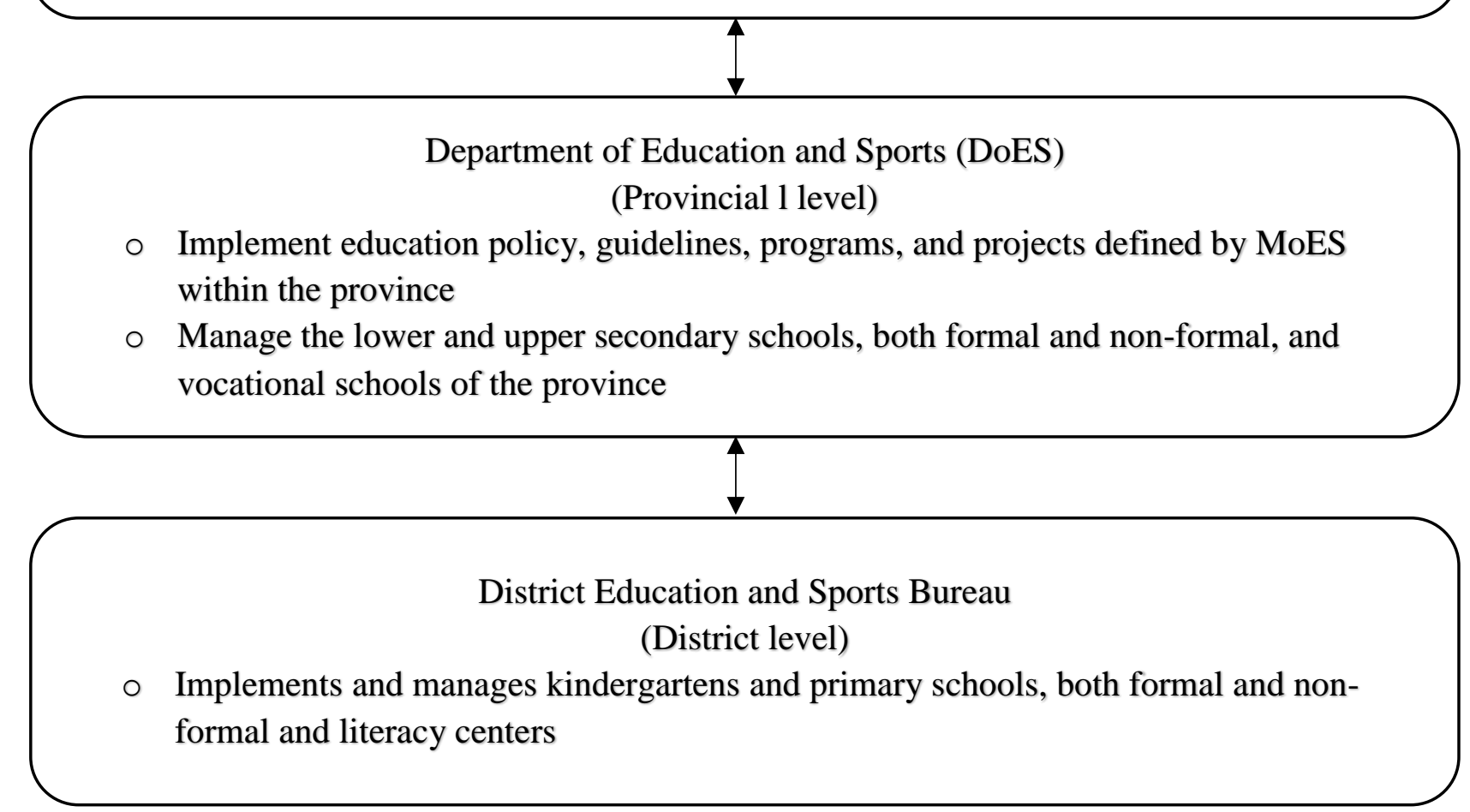

Source: Ogawa (2009, p. 298)

Effective education administration and management at all levels has been affected by limited funding (SaengOuthay, 2015). The governors control all financial management in education, along with the finances of a province. Prioritised provinces might gain sufficient budget to mean that education development plans in the province can be smoothly implemented and gain more productive outcomes. In contrast, non-prioritised provinces might have to wait for the support from international organisations (Phommalangsy, 2013). Overall, the education sector gets a low share of national budget distributions. For example, over the fiscal years of 2008-2009 to 2011-2012, the education sector received only 11 to 12 percent of the total national budget (MoES, 2013). However, in the fiscal year 2012-2013, the NA approved allocating 18 percent of the national budget to the education sector (ibid) although this has still not resulted in improved education infrastructure in rural areas and improved teacher salaries (SaengOuthay, 2015). 


\subsubsection{Gender and education in Laos}

Human development in Laos is making progress, yet gender disparity still remains in many parts of the education system. The Lao male average literacy rate is far higher than their female counterparts. In 2000, for instance, an ADB study found that the male literacy rate was 74 percent, but the female literacy rate was only 48 percent (ADB, 2004). Gender gaps are also found in enrollment, dropout rates, and graduation rates (ibid). Moreover, the disparities are wider in higher levels of education. There are several causes of low attendance rates for females, particularly in rural areas, such as distance of school location, language barriers for minority groups, cost of school supplies and clothing, household responsibilities, and parents' concerns about school quality and safety of girls in schooling (ibid).

Overall, the roles of women and children in the family have not changed a lot between 1975 and at present. Women and children, in both urban or rural areas, and among minorities, are still needed at home for family work. Consequently, a high dropout rate of children has been found in primary education (Lao PDR, 1989). The situation is worse for poor rural girls. The study on 'schooling, poverty and disadvantage in the Lao People's Democratic Republic' by King and van de Walle (2007) found that poor rural girls spend fewer hours in school than working (the average was 5.3 hours a day working). They found that female labour in rural areas is nearly equally separated between on-farm agricultural work (2.0 to 2.2 hours per day) and domestic work (2.0 to 2.5 hours per day). Conversely, rural boys spend less time than girls on household tasks. They spend 1.7 to 2.1 hours a day on farming and one hour on fishing and hunting (ibid).

Girls from ethnic minority groups, poor families, and agricultural worker families find it harder to access schooling, and have higher dropout rates (Lao PDR, 1989). Even poor parents still have to pay for their children's education. King and van de Walle (2007) report that, for example, the cost of primary education per student is 16 percent of per capita household expenditure in urban areas and nine percent in rural areas. They also found that secondary education consumes around 21 to 22 percent of per capita household expenditure in both rural and urban areas. There are various costs that students' parents have to meet. King and van de Walle (2007) note that students' parents' spend for textbooks and materials is 20 to 25 percent per capita household expenditure in rural areas. While in urban areas students' parents' spend for transportation, meals, and lodging is around 21 percent per capita household expenditure. Family expenditure to support 
education increases with the level of education (ibid). Overall, the main causes of school dropout are the lack of financial support but also supporting a family by doing household tasks, and even working outside a home in order to earn more income for supporting a family. Education for girls has regularly been a secondary priority for children's schooling in Laos (Lao PDR, 1989).

Social norms on gender responsibilities within the household lead to some bias associated with girls' education. In addition, social norms also perceive that girls are less likely to get employment opportunities in the future (King \& van de Walle, 2007). This decreases the chances of girls' education. Ultimately, according to traditional perspectives, parents prefer boys to have more education than girls (ibid). Overall, gender-role stereotyping and traditional perceptions keep girls and women in subordinate positions and exclude them from equality in respect of economic opportunities and accessing education; even though Lao legalisation provides for equal rights for women (Edwards \& Girgis, 2015).

\subsubsection{Women, education and policies}

Internationally, investment in girls' education is predicted to improve economic and human development (Edwards \& Girgis, 2015). The Government of Laos and MoES prioritise women's literacy and girls/women having equal access to all levels of schooling for economic and human development. This is illustrated in the National Socio-Economic Development Plan 2006-2010: "to improve the education of the whole population it is necessary to concentrate on equitable access, quality, relevance and management of education. Increasing primary school attendance and literacy rates particularly for people in under-served areas, such as ethnic peoples, children with specials needs and girls, is an important foundation step ... Accessibility to quality secondary education has to be improved to raise the number of students entering and completing secondary education and hence going on to a third level education" (MoES, 2008c, p. 12). The goals have been continued in the next National Strategy and Plan of Action on Inclusive Education 2011-2015. This strategy also deals with the issues of gender inequality in schooling, as well as inequality associated with being urban or rural, with ethnicity, and with poverty (Edwards \& Girgis, 2015).

Furthermore, Millennium Development Goal 3 for Laos also focused on improvements in gender equality; particularly on improving the rights of all children and adolescent people to access education, raising awareness of gender equality and women's rights, and 
supporting women to increase opportunities to claim their rights in unfair cases (MoES, 2015). At present, SDG 4 (equal education) and SDG 5 (gender equality) have followed the MDGs (UN, 2017a). However, most of the policies and practice related to enhancing girls' education have been pushed by international organisations and other countries' recommendations, while there have been very few activities initiated by the Government of Laos themselves. Thus, Lao authorities and international agencies have to work together to ensure policies and programmes are appropriate for the country's unique, multi-ethnic context.

\subsection{Tertiary education}

The Government of Laos priorities are in the basic education sector, primary and secondary education, rather than tertiary education. However, the country is beginning to realise the significance of reinforcement of the post-basic education in parallel with emphasis on higher education due to globalisation and the introduction of the knowledge economy (Ogawa, 2009). Therefore, the government has to guarantee that both basic and academic education are established in a well-balanced education system (ibid). The MoES assigns the Department of Higher Education to take charge of the management and coordination of the higher education sector (ibid).

Investment from the government in higher education focuses on construction and rehabilitation of infrastructure for five public universities, including new buildings, teaching-learning facilities, science research and technical services (MoES, 2015). At present, higher education in Laos consists of: five public universities, namely National University of Laos (NUOL) (established in 1996), Champasak University (CU) (established in 2002), Souphanouvong University (SU) (established in 2003), University of Health Science in Lao PDR (established in 2007), and Savannakhet University (SKU) (established in 2009) (Ogawa, 2009); five teacher training centre (TTC); and 83 private higher institutions (Takita, 2010). Higher education offers academic, professional, and technical courses for upper secondary education graduates (ibid). It offers 3-year higher education, and 4- to 6-year bachelor's degree programmes (Ogawa, 2009).

Gross enrollment in higher education was only nine percent in 2006 (Takita, 2010). From that time enrollment rates in tertiary education have continually increased, in part due to rising secondary school attendance and increasing demand for vocational training or tertiary education (UNDP, 2015). Given the demand, registration rates in universities are 
actually over the target goal of the ESDF Policy Planning in 2015 (MoES, 2011), causing overcrowding and the need to teach some programmes at weekends (ibid).

Responding to demand, private tertiary institutions have expanded to receive a large number of students. However, these institutions offer a poor quality of education as they focus more on quantity rather than quality (MoES, 2011). Most new private higher education institutions (HEIs) are unregulated (Siharath, 2010), and there is poor coordination between higher education administrations in the public and private sectors (MoES, 2015). In addition, private higher education authorities have low capacity in respect of leadership, administrative management, planning and implementation (ibid). Overall, it is the urgent responsibility of the Government to produce standards and quality assurance procedures to ensure the quality of the private HEIs(Siharath, 2010). Moreover, it is also important to consider the association between quality standards and the demands of the labour market during the development of a regulatory framework for private HEIs (ibid).

Tertiary education planning is currently out of alignment with human resources development and socio-economic development plans (MoES, 2011). Siharath (2010), for example, found that there is no available survey on labour market projections in order to gauge the implementation of higher education systems or planning. He also noted that 93 percent of the labour force work in unpaid family labour and own businesses, and only seven percent are formal employees in public and private offices (ibid). Overall, most students in higher education are interested in the programmes that they think will help them to easily find a job and gain high salaries (MoES, 2015). Unfortunately, higher education curricula and textbooks are out of date (Siharath, 2010) and not consistent with the demands of the labour market (MoES, 2015). As a result, the abilities of graduate students do not always meet employers' demand. In addition, results from employer surveys and reports from students who graduated from HEIs in 2014 suggest that some graduates are still lacking management and professional skills (ibid).

Another factor that leads to the poor quality of higher education is limited qualifications of staff and lecturers in higher education institutes in both the public and private sectors. University lecturers in Laos have a scarcity of scientific knowledge when compared with other countries (Rehbein, 2007). Lecturers with PhD degrees are at less than five percent, which is usually the minimum standard for western university teachers (ibid). In addition, 
there are insufficient lecturers in private HEIs, and most are only guest lecturers from public HEIs (MoES, 2015). Because of the low wages paid to academic staff, public HEIs have difficulties keeping experienced and proficient academic officers, leaving public HEIs with mainly young, less experienced, and unqualified staff (Siharath, 2010). In addition, the government budget for public HEIs is only for staff salaries and administrative work, meaning funds for professional development is very limited (MoES, 2015).

Equitable access to tertiary education also still needs to be addressed (Takita, 2010). For example, attendance of ethnic minority groups is low (ibid). In addition, there remains a large number of students not progressing to tertiary education (ibid). Takita (2010) reports, for instance, that during the academic year 2006 to 2007 , of the 44,762 graduates of upper secondary schools, only18,850 continued to higher education, even with the recent expansion in the sector. The obstacles to secondary and higher schooling include the financial costs that bear upon families (related to the lack of scholarships, costs of transportation and the poor quality of public education) and the remoteness of many communities which makes daily commuting to school impossible (UNFPA, 2015).

\subsection{Summary}

Laos remains a Least Developed Country (LDC) and the priority goal of the Government is to graduate from LDC status by 2020. Strong recent economic growth may enable this goal. Strongest growth is in the industrial sector, although the poor and women are not benefiting significantly. Family and cultural expectations still impact on women's roles. Women, for example, are expected to work for families, leaving education early, and developing working skills is a second priority.

Education in Laos has been facing many issues, including poor quality learning and teaching, insufficient and poor quality of staff, and limited funding. Enrollment rates need to be improved. There are high dropout rates from school at all levels, especially for females. Gender gaps still exist, although the government goals are being met at some levels, including tertiary education. The key concerns of this research will focus on women and tertiary education. It will focus on both barriers to and motivations for women regarding access to tertiary education. 


\section{Chapter 4: Methodology}

\subsection{Introduction}

This chapter describes the methodology used for the research. It begins by explaining how a feminist theoretical framework was applied to the research. Three feminist perspectives - liberal, radical and socialist feminist - are also presented. Research methods used will then be illustrated including qualitative methods using semi-structured interviews and document reviews of secondary information. The sampling and research participant selection, transcription and data analysis methods used will then be introduced. The location for data collection will be described. Finally, some ethical issues will be raised that I needed to take into consideration before and during fieldwork.

\subsection{Feminist theoretical framework}

"A feminist theoretical framework addresses the question of women's subordination to men: how this arose, how and why it is perpetuated, how it might be change and (sometimes) what life would be like without it" (Acker, 1987, p. 421). Feminist research is concerned with the experiences and perceptions of women and seeks to challenge and reverse the imbalances of power that usually exist between participants and the researcher (Kumar, 2011). Further, feminist research in education helps to reveal the ways women's issues and experiences have traditionally been excluded from research and academia (Skelton, Francis, \& Smulyan, 2006). This research will use a feminist lens to examine and analyse the influences on women's access to tertiary education as feminist theory directly concentrates on women's issues.

Additionally, the research will examine how family attitudes affect women's education. Allen and Jaramillo-Sierra (2015, p. 95) suggest that "feminists see families as complex, where love, care, and conflict co-mingle, and members have ambivalent and contradictory emotions about one other". Therefore, using feminist theory will help me to be more aware of family structures and how families support their family members' education. The theory will also help me to understand why families, including those in Laos, typically encourage males to study while females have to stay home and do unpaid work. Three feminist perspectives will be applied, liberal, radical and social perspectives.

\subsubsection{Liberal feminist theory}

Liberal feminist theory was developed largely in response to Western feminists' concerns regarding gender inequalities in the economic sphere. It was applied to a development 
context in the pioneering work of (Boserup, 1970). "Liberal feminist activities are concerned with ensuring that laws and policies do not discriminate against women and that women have equal opportunities in all aspects of life" (Parpart, Connelly, \& Barriteau, 2000, p. 116). "The intent of liberal feminists in education is to remove barriers which prevent girls reaching their full potential, whether such barriers are located in the school, the individual psyche or discriminatory labour practices" (Acker, 1987, p. 423). This perspective helps a researcher to be aware of and to consider the existing policies of the Government of Laos and HEIs as they impact on women and their education.

\subsubsection{Radical feminist theory}

Radical feminist theory has been concerned with the way gender roles have been socially constructed. It is particularly concerned with patriarchy: the system of male domination and oppression. "Radical feminists are engaged in a power struggle with men" (Acker, 1987, p. 421) and they argue that women have less power than men (Stromquist, 1989). "Radical feminists in education have concentrated mainly on the male monopolisation of knowledge and culture and on sexual politics in schools" (Acker, 1987, p. 419). A radical feminist lens in this research supports an analysis of the power imbalance between men and women in families, schools and societies in Laos. This feminist lens helps the researcher to be aware of imbalance in power in a household. It helps to focus on why and how women tend to have responsibilities for household chores that may impact on time spent on schooling.

\subsubsection{Socialist feminist theory}

Drawing on Marxist theory, socialist feminism focuses on the way capitalism constructs gendered inequalities in the workplace. It highlights the subordination of women through both productive and reproductive labour roles and relationships. "Socialist feminism is based on the belief that the economic and class structure of our society is inherently problematic, which leads to multiple forms of oppression" (Campbell \& Wasco, 2000, p. 776). "It interprets the patterns in light of the restricted opportunities for women to participate in the paid labor force as well as the patriarchal power base of the home" (Blieszner, 1993, p. 176). From a socialist feminist perspective, social norms dictate that females are less likely to get outside work, so they do not need to study much, only work and help the family; or if they do seek wage labour, it will be in the low-paid, unskilled segments of the labour force. The social feminist perspective calls attention to the social division of labour in the family as well as in the workplace (Campbell \& Wasco, 2000). 
This perspective helps to analyse the role of girls and women in a family and within social structures. It also assists us to analyse how and why social norms, with regard to women, impact on the family and women's decisions regarding their education. Combined, these three feminist perspectives help us to analyse the condition of women and family support to access tertiary education.

Figure 4.5: The linkages between feminist theories and research questions

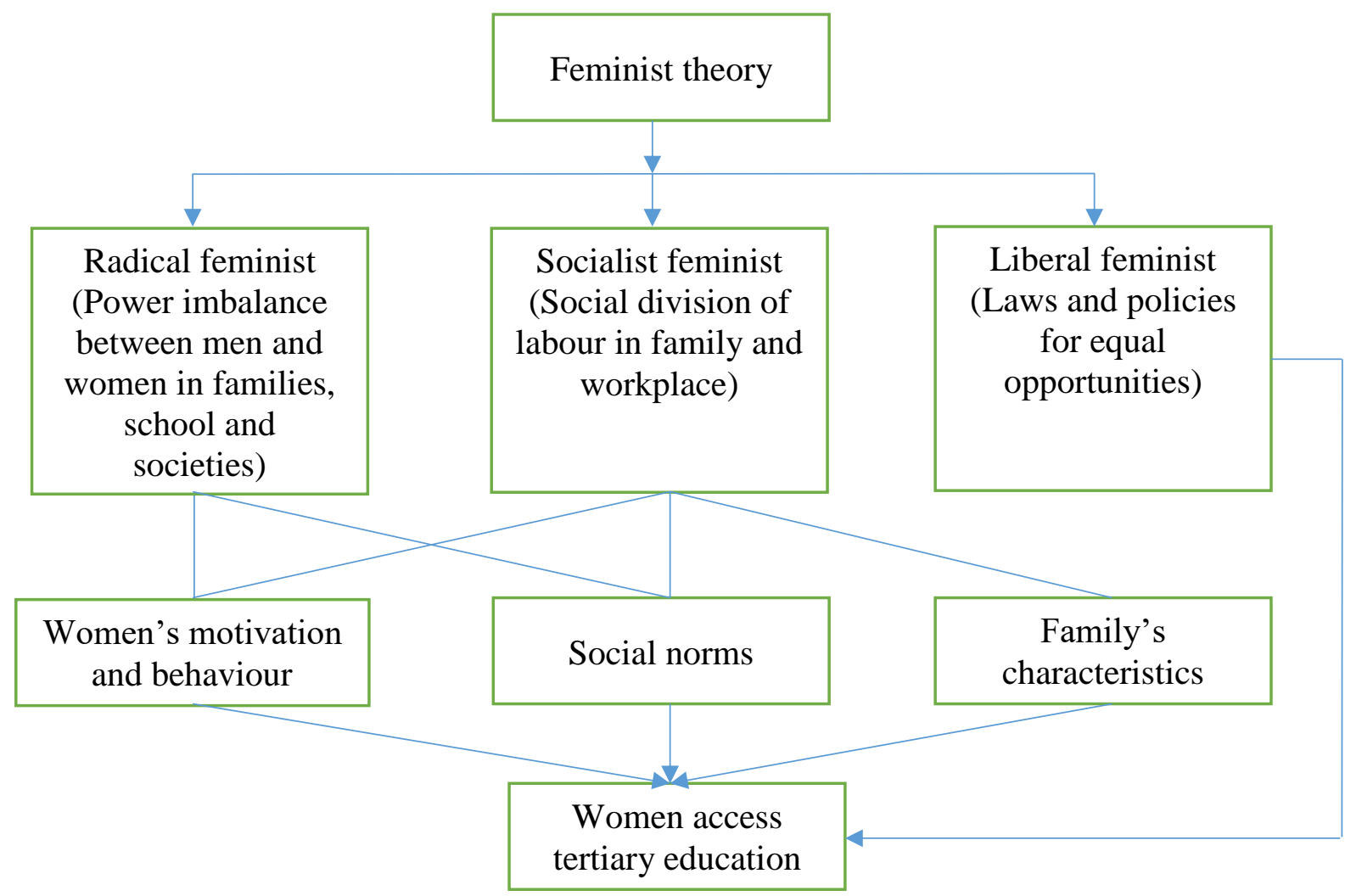

\subsection{Research epistemology}

This research focuses on feminist epistemologies. Epistemology is concerned with the way knowledge is created and spread (Creswell, 2013). "Feminist epistemology can be regarded as the branch of social epistemology that investigates the influence of socially constructed conceptions and norms of gender and gender-specific interests and experiences on the production of knowledge" (Anderson, 1995, p. 98). Feminist epistemologies acknowledge the stories of women's lives as knowledge, and through the process of sharing those stories, they embody an ethic of caring (Campbell \& Wasco, 2000). In this research, feminist epistemology assists us to understand how and why gender makes a difference to knowing; how and why gender leads to different perceptions of males' and females' education; as well as how and why gender leads to different 
treatment of males and females. This understanding and knowledge is gained from real stories and sharing of experiences and the current situation of participants such as women, parents and tertiary education officers in Laos.

\subsection{Research methods}

This thesis aims to explore and analyse women's access to tertiary education, by focusing on women's behaviour, motivations, inspirations, as well as parents' characteristics (including family size, parents' education and occupation, division of household chores, and parents' status) and social norms. The research applies feminist theory. It also draws heavily on qualitative methods because these are consistent with a feminist epistemology and are particularly useful for revealing our understanding of the voices of different participants and, especially, for examining gendered perspectives (Ropers-Huilman \& Winters, 2011). I used semi-structured interviews to interview participants and key informants. I also utilised document reviews for secondary information - looking at policies, implementation strategies, and implementation reports. Statistics regarding women and education were also collected from relevant public and private organisations.

\subsubsection{Qualitative research}

Qualitative research can assist a researcher to investigate people's attitudes, aspirations, motivations, concerns, and culture (Conrad, Haworth, \& Lattuca, 2001). Thus, utilising qualitative research methods supports exploring women's attitudes and behaviours, how women value education, and their aspirations and motivations. Importantly, qualitative methods will support exploring parents' perspectives on how children thrive, children's responsibilities, and education. "Qualitative research is an umbrella term for a wide variety of approaches to and methods for the study of natural social life" (Saldana, 2011, p. 4). A qualitative approach is applied to explore the personal impacts of social structures, and the causes of individual behavior (Scheyvens \& Storey, 2003). Qualitative research allows participants to express their opinions and experiences in a deep, detailed manner (Creswell, 2013). Qualitative research also helps to explore opinions, perceptions, and values regarding women and tertiary education, which are complex and difficult to measure quantitatively. Sharing opinions and real-life experiences of participants helps to get detail of people's feelings and perceptions. The approach also enables women's individual perspectives to be explored, and to further understand the value of tertiary education for women. 


\subsubsection{Interviews (semi-structured interviews)}

Using a qualitative methodology, this research adopted semi-structured interviews as the principal research method to gather data on women and tertiary education. "Qualitative research interviews involve gathering information, facts, eliciting stories, and learning about meanings, emotions, experiences, and relationships that cannot easily be observed" (Rossetto, 2014, p. 483). A qualitative interview is a process of gathering in-depth information (Johnston, 2010) and begins by asking people to talk and / or listening to them, and then constructing knowledge by interpreting their words, expressions and reactions (Bauman et al., 2002). Active involvement from an interviewer and an interviewee in an in-depth discussion is an essential feature of such interviews (ibid).

Interviews aim to address the research objectives by utilising a set of questions and following a structured or semi-structured interview format (Johnston, 2010). "Semistructured interviews follow a form of interview schedule with suggested themes, but there is scope for the interviewees to develop their responses" (Desai \& Potter, 2006, p. 146), and for the interviewer to be flexible with questioning. Overall, semi-structured interviews let interviewers and interviewees interact and exchange information in a flexible and open style, allowing an interviewer to ask in more detail about particular issues for which information or questions are not necessarily prepared (Davidson \& Tolich, 2003). Therefore, I used semi-structured interviews in this research as they enabled me to adjust and/or add more questions to attain more detailed information according to participant's particular responses. Yet the themes and questions had been developed before the fieldwork as a guide to extend or curb the defined areas of the research. During the interviews, I tried to follow up participants' responses with further asking to gain as much information as possible.

For female participants, I decided to interview them one by one in order to make them feel more relaxed. This environment helped them to talk and share their feelings, experiences, opinions and stories generously. While most of the interviews were only the participant and I, there were a few interviews where participant's family members were involved in listening and answering some questions, although I tried to particularly follow and concentrate on participant's responses. For parental participants, I decided to interview both the father and mother at the same time, depending on their availability, to gain information related to parents' involvement in their daughters' education. The use of audio-recording during the interview was important. I utilised audio-recording in every 
interview and I asked for permission every time before using the dictaphone. Voice recording was very helpful, as it enabled me to be fully involved in the discussion without the need to take notes.

\subsubsection{Document review}

Before fieldwork, some printed and online sources were searched and collected. Missing information, to be collected from the field, was listed before beginning fieldwork. This included information on the number of women in tertiary education, the gender gap in education, parents' economic status, education policies for students as well as women, Lao culture, and women's development. I also contacted, and met with, public and private offices to obtain information, including the Higher Education Department in the MoES, the Department of Education and Sports (DoES) of Vientiane Capital, the Department of Culture in the Ministry of Information, Culture and Tourism, the Lao Women's Union, NUOL, and Rattana College.

\subsubsection{Research location}

The research took place in Vientiane, the capital of Laos because there are many tertiary institutions: one national university, one university of health sciences and more than 35 public and private higher colleges (Onphanhdala \& Suruga, 2006). Given the higher number of tertiary education institutions in Vientiane, the access of women to tertiary education was greater than in other provinces. Furthermore, Vientiane is the most rapidly developing city in Laos in terms of economic development, population increase, and educational development (ibid). The population was 997,000 in 2015 (Laos Demographics Profile, 2017). It is also a location where it is easier to find participants who are not enrolled in tertiary education and come from diverse households (high, medium and low socio-economic backgrounds, diverse occupations and education of all levels).

\subsection{Research sampling and selection}

To obtain efficient and sufficient data during the three months of fieldwork, I directly selected young women in the age bracket of between 18 to 25 years old, as the research focuses on tertiary education. The research sample included current female students in tertiary education institutions and those who had never been enrolled. Female students were particularly targeted regarding their motivations and the advantages their parents gave them to support access to tertiary education. While women who were not tertiary 
students were particularly targeted regarding their motivations, barriers and any potential factors that pushed them away from tertiary education. In addition to women in the 18 the 25 year old bracket, parents of women either in tertiary education or not were interviewed to gain information related to assistances or barriers to their daughters' education.

There are several sampling strategies for qualitative research including judgmental, purposive, accidental, snowballing and expert (Kumar, 2011). Purposive and snowball techniques were used to gain participants for this research. Purposive sampling involved the deliberate choice of a person with specific knowledge and qualities due to the qualities the informant possesses (Tongco, 2007). Snowballing is "a technique for finding subjects where one subject gives the researcher the name of another, who in turn provides the name of a third, and so on" (Vogt, 2005, p. 300). The snowballing technique for searching and selecting samples is a useful method to mitigate sample bias, keeping confidentiality and boosting rationality of research finding (Cohen \& Arieli, 2011).

To gain female and parent participants, firstly, I used purposive techniques. I listed all participants including criteria and number and then consulted with the head of the village/community. By these criteria, the head of the community nominated community members that matched the criteria. Snowball techniques also helped me to reach more participants as some of the originally nominated community members were not available. I asked completed interviewees to suggest someone they knew who matched my criteria. For female students, I contacted the NUOL and Rattana College to obtain their approval and then randomly interviewed their students. 
Table 4.1: List of participants (women and parents)

\begin{tabular}{|c|l|l|}
\hline $\begin{array}{c}\text { Number of } \\
\text { interviews }\end{array}$ & \multicolumn{1}{|c|}{ Description } & \multicolumn{1}{|c|}{ Specific characteristics } \\
\hline 10 & $\begin{array}{l}\text { Women who are enrolled in tertiary } \\
\text { education (age 18 - 25) }\end{array}$ & University or college \\
\hline 10 & $\begin{array}{l}\text { Women who are not enrolled in } \\
\text { tertiary education (age 18 - 25) }\end{array}$ & $\begin{array}{l}\text { Unemployment } \\
\text { Own small business } \\
\text { Married } \\
\text { Single }\end{array}$ \\
\hline 2 & $\begin{array}{l}\text { Parents of women who are enrolled in } \\
\text { tertiary education }\end{array}$ & $\begin{array}{l}\text { Couple } \\
\text { Single parents (women/men) } \\
\text { Low income } \\
\text { High income } \\
\text { Occupations } \\
\text { Education level }\end{array}$ \\
\hline 2 & $\begin{array}{l}\text { Parents of women who are not } \\
\text { enrolled in tertiary education }\end{array}$ & \\
\hline 24 & \multicolumn{2}{|}{} \\
\hline
\end{tabular}

In addition to the interviewing, key informants - public and private senior officers - were also contacted and interviewed. I applied the purposive technique to obtain a sample for this group. The detail of key informants is in the table below:

Table 4.2: List of participants (key informants)

\begin{tabular}{|c|l|l|}
\hline No & \multicolumn{1}{|c|}{ Organisation } & \multicolumn{1}{c|}{ Information needed } \\
\hline 1 & $\begin{array}{l}\text { Higher Education Department, } \\
\text { Ministry of Education and Sports }\end{array}$ & $\begin{array}{l}\text { Current situation and policies of higher } \\
\text { education in Laos }\end{array}$ \\
\hline 1 & $\begin{array}{l}\text { Department of Education and } \\
\text { Sports, Vientiane }\end{array}$ & $\begin{array}{l}\text { Current situation of female students in } \\
\text { Vientiane, especially in higher education }\end{array}$ \\
\hline 1 & Lao Women's Union & $\begin{array}{l}\text { Lao women's issues and development, } \\
\text { especially education and some policies }\end{array}$ \\
\hline 1 & $\begin{array}{l}\text { Department of Culture, Ministry } \\
\text { of Information, Culture and } \\
\text { Tourism }\end{array}$ & $\begin{array}{l}\text { Lao culture, Lao women and their role in } \\
\text { the family }\end{array}$ \\
\hline 1 & $\begin{array}{l}\text { National University of Laos } \\
\text { Female students' situation including } \\
\text { quantity and quality of study and policies } \\
\text { for female students }\end{array}$ \\
\hline 1 & Rattana College & $\begin{array}{l}\text { Female students' situation including } \\
\text { quantity and quality of study and policies } \\
\text { for female students }\end{array}$ \\
\hline 6 & & \\
\hline
\end{tabular}


Figure 4.6: The linkage between target participants and the research questions

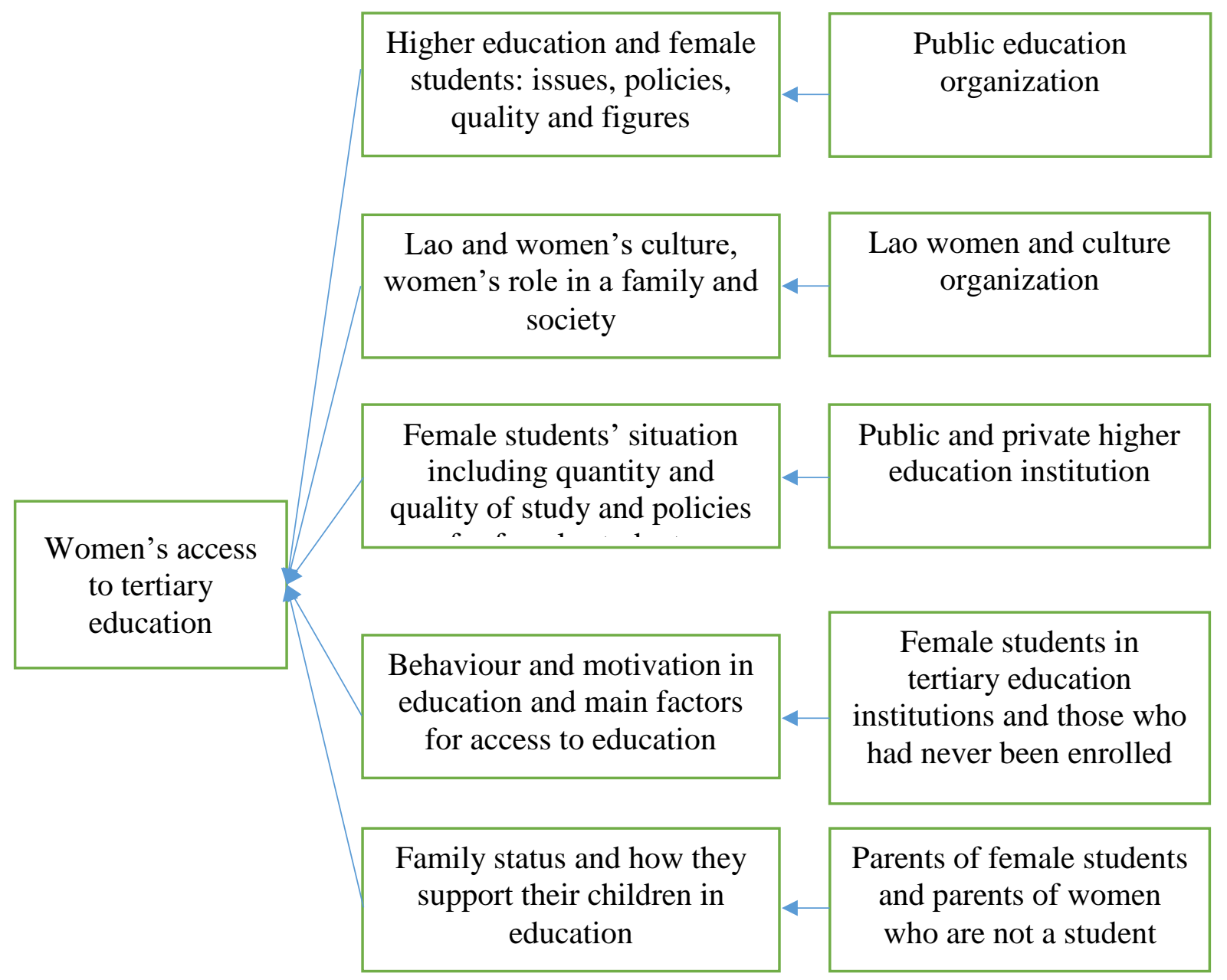

\subsection{Transcription and analysis}

\subsubsection{Transcription}

Transcribing was important for in this research as it illustrates experiences, opinions and feelings of my participants (Bailey, 2008). I tried to transcribe the voice recording to my computer at the end of the interview day, including backing-up the voice recording for security. Listening to the recording before starting transcription helped me to understand the main points of discussion and comprehend the most relevant answers to my questions. However, I avoided transcribing every word from the discussion to save time and also to reduce a lot of text. Moreover, all of the interviews were conducted in Lao, and I had to spend time translating them into English.

\subsubsection{Data analysis}

Before conducting field work, themes/patterns were developed from sub-research questions and relevant issues concerning women and education. While conducting field work, some new themes were added according to information provided by participants 
and key informants. After transcription, the written data were divided into four categories and entered into a prepared Excel file - key informants; female students; women who are not a student in a tertiary education institution; and parents. Similar questions and answers were grouped and analysed according to the main theme. A mind map was also a helpful technique to help with data analysis when I had a lot of information to summarise.

\subsection{Researcher's positionality}

Positionality is an acknowledgement by the researcher that her or his own position in relation to the research "may influence aspects of the study, such as the types of information collected, or the way in which it is interpreted" (Sultana, 2015, p. 376). Positionality of the researcher can involve aspects such as gender, religion, social class, and ethnicity, and it is important to acknowledge it as it can affect relationships with, and responses from, participants.

Considering positionality in this research helped me to be aware of my position as insider and outsider. Being a Lao woman, I am somewhat of an insider, but in some ways I was an outsider too as a woman who completed tertiary education some years ago. Therefore, when interviewing women who were different to me, I needed to be aware of my stereotypes and my potential judgements of others. In addition, as the researcher/interviewer, I had power to some extent. I tried to hide my power by being friendly and using normal words like a sister and younger sister would during interviews with participants, especially with those who have had no chance to attend higher schooling. Reflection is helpful for me in reflecting on my questions and the way I asked them. After the first interview, I had some reflections on my questions and to way I formulated them. This reflection leads me to select the information I really need and the one I could leave. Then, I could directly contact participants for further interview

\subsection{Ethical considerations}

It is essential to consider ethical issues in social research involving participant interviews. Being ethical is also about interacting in a manner that is sensitive and respectful of participants. "Ethical research should not only do no harm, but also have a potential to do good, to involve empowerment" (Madge, 1997, p. 114). Ethical approval from Victoria University of Wellington Human Ethnics Committee was obtained before going to do the field work. The following ethical issues were particularly important: 


\section{Informed consent}

All participants were voluntary and never forced (Scheyvens \& Storey, 2003). Before discussing any details, I started by getting participants to read and sign a statement highlighting the participant's rights, and informing them of how they can get involved in the research.

\section{Confidentiality}

The identity of the participants was confidential. A code number was used to refer to a participant's name or address. Information on participants will be kept and eventually discarded according to Victoria University of Wellington's policy and procedures.

\subsection{Summary}

This research used feminist lenses to guide the study on women's issues regarding access tertiary education. Qualitative research methods were used to seek understanding of Lao social phenomena, education and women. Semi-structured interviews were utilized to interview all participants, including female students, women who were not students of any tertiary institution, and parents and key informants, to gain opinions, experiences and feelings. Additionality, document reviews were also used in this research to collect secondary data. Transcription and data analysis have been used following the completion of the fieldwork. The findings will illustrate the completed analysis in the next chapter. 


\section{Chapter 5: Key results: Families, women's preferences, and social norms}

\subsection{Introduction}

This chapter explores family characteristics, preferences and behaviours of women, and social norms, which influence access to tertiary education. It presents findings from semistructured interviews in the field and document reviews regarding sub-research questions 1, 2 and 3 (see section 1.4 in chapter 1). The first section of the chapter investigates how a family's characteristics, including of income, family size, parents' status and discipline in children's education, influence women's education. The second section examines behaviours, preferences and expectations of women, and women's current job situations. Social norms regarding family roles, job opportunities and youth problems are reported in the next section. The last section focuses on policies for tertiary education enrollment.

\subsection{Family characteristics}

\subsubsection{Family}

A family is a small unit in a society and it is defined as "a group of persons united by ties of marriage, blood or adoption constituting a single household interacting and intercommunicating with each other in their respective social roles of husband and wife, father and mother, son and daughter, brother and sister..." (Mahdavinejad \& Moradchelleh, 2012, p. 1069). A family is an element of society, and is fundamental for childbearing, nurturing and disciplining. The 1990 Lao Family Law, in Article 32, notes the obligation of parents regarding children's education as "parents must educate their children on patriotism, progressiveness and pure livelihood, to lead activities useful for society" (Lao PDR, 1990, p. 7). The Government of Laos also emphasised gender equality in the Family Law in Article 2 stating “...men and women have equal rights in all aspects pertaining to family relations" (Lao PDR, 1990, p. 1).

\subsubsection{Family economic status}

A family's economic status has various influential factors on children accessing and attaining education. A family's economic status in this research consists of parents' occupation and income (Yadollahi \& Paim, 2010). From interviews, women who are not enrolled in tertiary education (WNTE) ${ }^{1}$ report that their parents are retailers, peasants and

\footnotetext{
${ }^{1}$ WNTE is used to refer to a woman who is not enrolled in tertiary education
} 
blue-collar workers. The families' incomes are quite low and unstable. They are poor and less likely to have money to save at the end of the month. Thus, it is difficult to support the daughters to attend higher education institutions (HEI). For example:

My parents are farmers. They do rice farming two times a year, then sell it. We have a small plot of land and use basic techniques. We do not get a high production outcome. My brother has to go fishing at the weekend. I and my mum do home gardening. But fishing and gardening are for home consumption only. That's why our family has very low income and are unable to save money (WNTE10).

Low economic status is unlikely to create barriers to children accessing education at primary and secondary levels, as the enrollment fees and services are not expensive, particularly in public schools. However, this changes for tertiary education. For example:

When I was in secondary education, I didn't know that my family didn't have enough money to pay for my education after secondary school, but when I wanted to continue my study they said that it is too expensive. They emphasised that it is not only the enrollment fee, but it also includes study material resources, uniforms and transportation (WNTE 10).

However, over half of women who are currently studying in a tertiary education institution (WTE) $)^{2}$ report that their family also face financial hardship, as their parents are peasants and small retailers and don't have a large income. Some of them gain support from siblings or relatives. For example:

Even though my parents are farmers and not educated, they had tried to do other work such as forestry gathering. With the help from my uncle and parents, they could support my brother to study at TVET; he then got a job at a mining company after graduating. Now he and my uncle support me to study at NUOL (WTE7).

\footnotetext{
${ }^{2}$ WTE is used to refer to a woman who is currently studying in a tertiary education institution
} 
A few WTE report that their parents have white-collar jobs, such as teachers and civil servants, providing a stable income. Thus, the parents can encourage their children's education, both in respect of finance and knowledge. Families of high economic status can also offer material resources for their children's education and also fund some special courses after regular class, such as mathematics, biology, chemistry and English language, which subjects are needed in the final examination in secondary school and the entrance examination in all tertiary education in Laos. Furthermore, high economic status families, particularly those with parents in academic positions, are more likely to be able to provide some academic guidance for their children. For example:

My mum is a biology teacher, and she wanted me to study the same subject as her. When I knew that I got entry into NOUL, I selected biology to be my major programme. During my study, I always consulted on any ambiguous points with her and she can obviously explain these to me (WTE9)

\subsubsection{Parental status and family members' responsibilities}

A father and a mother are two people who support a whole family. They have different roles and influences on children's education. In Laos a father has typically been recognised as an income earner and a mother has typically been recognised as a housewife. When one person is missing, only one parent is available to lead responsibilities for both roles, in such cases, supporting children for full education seems to be more difficult. In interviews, three WNTE and one WTE reported that they have a single parent or no parents. As two examples:

My father was a government officer and all his salary was for supporting the family. While my mother is a retailer and a housewife. My father tended to be a teacher for his children's education and he tried to push us to study after school. When he passed away, no one could perform as my father. My mother completed only fifth grade and she was not able to teach us. She has less available time as she has to do more work in order to gain income to compensate for the missed salary of my father (WNTE1).

When my parents passed away, I realised that I cannot continue to study further than at secondary school. My brother still gave me some money to go to a secondary school. When I graduated from there, I decided to work at a mushroom 
farm and earn some money for my life. My salary is very low, and I know that it is not enough for higher education (WNTE9)

A high number of family members means high expenditure, particularly given the high living costs of Vientiane. While Vientiane is the capital city, there is still a shortage of full-time and part-time jobs for teenagers and a general lack of variety of jobs. This restricts the potential for teenagers to gain a job and earn an income to help a family. When there are many children in a family, the two sources of income might not be enough to feed all family members. For example:

I have eight sisters; nine, including me. My father is the only man in the family who earns an income. Due to too many daughters, my parents cannot support everyone to post-secondary education and there is a lack of intimacy and consultation between all family members. Hence, I and my siblings have not had a chance to study after graduating from secondary school and we directly got married and have our own families (WNTE1).

A large family size can create an imbalance of household work responsibilities. Some of the WNTE's families are of a large size, where there are more than five siblings within a family. Large family sizes mean a large amount of family household work, the majority of which is done by females. However, most reports from interviews note that the household chores are not a huge amount of work. It is only cooking and cleaning, and it takes less than two hours a day. They can do these chores after school, meaning it does not impact education. Male siblings, on the other hand, go out and do some activities with their friends such as playing sports, games, and travelling around the city on their motorcycles. Overall, their activities after school are more social than female counterparts. For example:

I have two brothers and I am the youngest sister in our family. We have five people in our family. There is no household task management in my family. Only I have to be responsible for household work. My two brothers rarely do household work. They rarely stay at home after school and they like to go out with their friends. I don't know what they do outside home. Ifeel bad letting my mum do the household tasks alone. My mum also has a small grocery shop in front of our house. Thus, it is not only household work that I have to do, I also have to help my mum with her grocery shop (WNTE6). 
Conversely, more than half of WTE reported that their family's size was less than six people and their parents have never managed or divided household chores for each child. Only a few WTE families (teacher families) have managed and required all members in the family to be involved in household tasks, although this simple management can balance household tasks and reduce overload for a particular family member. Most of WTE and WNTE see household management as less important, particularly in big families. For example:

My father set schedules for household chores, when I was in primary school. Daughters did some cooking and sons did some washing and cleaning and we took it in turns each day. Helping each other with household work, it did not only help create more time for me to study, but it also created solidarity among siblings. My father stopped setting schedules when we were in secondary school as everyone comprehended their responsibilities and were being tender-hearted (WTE8).

All female participants perceive that household chores are female duties, and they also are more concerned about family management than males. Participants reported family expectations around household work, for example:

I have to do household tasks; this is my role. I have only one younger brother, I am also the oldest sibling in the house. My younger brother also does not know how to do household tasks. As I am women, I have to do this. My parents also instruct that " a woman has to do household chores in order to be a good wife and mother", as I will be a wife and a mother, then I will be able to take care of my husband and teach my children (WNTE5).

However, almost all women, whether in tertiary education or not, reported that doing household chores do not impact on their quality of study. A few WNTE did report that household tasks left them feeling overloaded, typically those from large male dominated families. WNTE who have to take care of household chores feel that it is unfair. They want to study instead of working at home doing the same repeated work every day. They feel that male siblings should also take part in doing housework. Some of them express 
their dissatisfaction with their mothers, but they rarely directly complain to the brothers as they want to avoid conflict between siblings.

\subsubsection{Study discipline}

Interviews support that families who pay more attention to children's education in early life, such as supporting tutorials after school, and providing guidance, have children that are more successful in education. Most WNTE report that their parents were able to provide them with basic teaching after school. However, while parents were able to provide basic teaching when they were in primary school, they are not able to do this at a higher level due to the low level of education of the parents. Attendance in a special tutorial class after school is one of the solutions to improve quality of learning, yet it requires funding and time. This condition seems to impact the poor and poorly educated families the most. For example:

My parents were unable to guide me with difficult homework. My father graduated from secondary school and my mother graduated from primary school. They prefer to spend most of their time on their work to earn money rather than spending some time with the children. I sometimes joined tutorial classes after school when I got some money from my mum, but not regularly. Therefore, my result scores were not good compared to my classmates who joined special tutorial classes (WNTE1).

However, most parents of WTE reported that they supported WTE by providing school fees, and providing guidance and suggestions to their children. Some parents of WNTE have less time to provide guidance and encouragement for their children's education. For example:

My parents occasionally told me to revise or reflect on the lessons. I hardly did that too, mostly I learned from school only. Then I felt I am not familiar with hard study or with studying after school, as I arrived home, I directly did other activities instead. My study quality was normally low in classes (WNTE1)

In contrast, most parents of WTE concentrated on education in early life. They strove to support their children's education, even though they may have little income. They would also ask for help from their relatives, in case of urgent need. Not only that, they always followed up about their children's study results, and if necessary, they would support 
their children to attend special tutorial classes. Furthermore, they also encouraged their children to be familiar with study after school by revision of and reflections on lessons learned. Almost all WTE parents reported that they also gave encouraging words to their children when they felt confused and disheartened. For example:

Starting from at primary school, my parents did not let me and my brother have a lot of free time. They encouraged us to spend time in study (WTE6).

"If you study, you can easily earn money and take care of yourself, if you do not study, you will not know how to do anything”; my father's suggestion (WTE6).

"Even though we are not rich, I will try hard to earn money to support you. I will support you to study more than I did. When I was young I could not study because my parents did not have money, but now I will support you to study higher than I did", my father said (WTE7)

Parents also expressed more anxiety about daughters than sons regarding safety and early sexual relationships. For example, they were less likely to allow teenage daughters to go out at night. Parents seemed to prefer that daughters should come directly home after school and help their mother with cooking and cleaning rather than enjoy a social life as sons typically do. Parents perceive that sons are strong and that they are more able to take care of themselves than daughters, meaning parents do not worry about sons as much as daughters. This may impact on women joining school activities or study groups after class. For example:

Most of the parents in my community seem to worry about daughters more than sons. My parents, as well, feel more worries about me. They do not want me to go out at night. They worry about my safety and close relationships with male friends (WNTE8).

Overall, parents support children with material resources and all fees for education. Parents are also the main people to teach children to like learning by encouraging them to study regularly. Parents are also a good advisor for their children's education. However, some parents have some worries with females, which will impact their education. 


\subsection{Women's behaviors and preferences}

\subsubsection{Women's behaviours, preferences and expectations}

\section{Behaviour}

Personal behaviours, preferences and expectations partially influence decision making on education, careers and marriage. For example, being dedicated and hardworking are traits of a person who will succeed in education. The research found that more than half of WNTE are typically shy, unassertive and indecisive. These people mentioned that they were not typically involved in classes when they were in primary education. For example, they spoke little or only occasionally asked for clarification for ambiguous points in classes, saying that they were afraid of making a mistake in class and being embarrassed. The general perception of female students is that they should be polite, gentle and respectful toward teachers, rather than freely expressing their feelings and desires. For example:

Personally, I am a shy and unassertive. I feel not confident to speak in front of many people, particularly in a school class. I always was quiet in classes. Some of my teachers said that I did not participate enough in class and was not studious (WNTE3).

Conversely, the general perception of female participants in the research was that male students were less likely to be afraid of making mistakes. They tend to be more confident and assertive.

Apart from family support such as funding, material resources, suggestions, and discipline, self-determination in being attentive in study is important for students. Almost all WNTE report that they attended entrance examinations held by TVET and HEI, but most of them did not pass the examinations. They said that the examinations were not very difficult, but due to their low quality of learning, lack of attention in study, and lack of preparation before taking the examinations, they did not succeed. They emphasised that they mostly preferred to spend time watching TV and playing with mobile phones rather than studying when they had free time. Conversely, more than half of WTE reported that they spent more time on study than on other activities. They determined to study hard from primary education onwards to develop themselves to ensure that they 
can deal with the harder level of education. These women also perceive that the entrance examination into HEI is more difficult than any examination they have taken before, as the areas of the examination cover the lessons from four years in upper secondary education. Therefore, they had to work harder and some of them also attended special preparation courses held by teachers in NUOL. Overall, they feel that they had not wasted their time and effort, as they have gained a significant achievement in being a student in HEIs. For example:

I and my sister always spent lots of time on study. During our free time, we liked to open a book and study. My study was quite good; I always got high scores in secondary school. After that I wanted to study at NUOL; I attended preparation courses. I did not know what the areas would be in the examination. Thus, I had to spend a lot of time and effort to study. Even when I felt very tired, I finally got it (WTE9)

\section{Preferences}

Most of WTE and WNTE wished to continue their study after secondary education, whether at TVET or HEIs. Some female research participants had no ideas around possible schools or courses. They had to consult with their parents, siblings or cousins. Therefore, courses of some WTE were chosen by their parents. Some WTE felt unsatisfied with their enrolled courses. They reported that they did not fully concentrate in classes, with the result that their grades were low. For example:

I got a scholarship to study in the Political Sciences, Faculties of Sciences, NUOL. Personally, I would have preferred to study at a kindergarten teaching TVET, but my brother said that I will get only a certificate, not a degree and it will be difficult for me to find a job. Finally, I followed my brother's suggestion. Whereas, Ifound that I don't like the political science course. It is too complicated, mostly regarding adult issues and conflicts. I would prefer to see small children and play with them rather than reading a lot to understand the politics. That's why I sometimes feel bored and I am not doing well at study now (WTE5)

While the majority of female participants want to keep going on their education further than secondary school, there were two WNTE who said that they preferred to do other activities. One WNTE reported that she did not want to study after secondary education 
at all, giving the reason that study at HEI such as NUOL takes at least four years, requires money for enrollments, uniforms, materials, and transportation for the whole four years, and the uncertainty of gaining a job after graduation. This participant preferred to help in a household business (small household grocery store), and earn money towards launching her own business rather than to burden their family by asking her parents' for money for all four years. Hence, she was working at the beer shop at night time and attending beauty training in the morning in a vocational training school. Then she plans to establish her own barber shop. Another WNTE reported that she is satisfied with her work as a cheer beer girl in restaurants, and that she wanted to collect money and create her own business of a massage spa shop in the near future:

I like doing grocery selling more than study; even if I graduate from higher education, I will do grocery selling. Grocery selling does not require high investment funds compared to study at higher education when I might get a low salary after graduation. Thus, I chose grocery selling (WNTE6)

\section{Expectations}

The majority of WNTE face financial hardship affecting their enrollment and study at HEIs. However, these participants still hoped that they will be able to afford tertiary education. Thus, they were working in a part-time or full-time job to save some money for their study. For example:

I graduated from a secondary school last year. My father wanted to support me to study, but I know that we don't have much money. I decided to work in a parttime job in a mini market near my village. I will apply to study Law in the Faculty of Law at NUOL this year and I will take care of my own expenditures during studying (WNTE10).

While most WTE expect to have a good job after graduation, they do worry about finding a job. For example:

I am currently in the fourth year of Biology programmes, Faculty of Sciences, NUOL. I will graduate at the end of this year, but I don't have any idea of where to work. However, studying is hard, finding a job is harder. I think the university should have a programme to make suggestions to students on job searching or 
any event that can gather students and employers to have a chance to meet each other (WNTE9).

Both WTE and WNTE place considerable emphasis on education even though they are all facing different difficulties. This is because they believe that education can help them to have a good job and success in their chosen careers. Most WTE tend to prefer working at government offices rather than private companies even though the public salary is quite low, noting that the work is more stable and offers better social welfare. In contrast, private companies make heavier demands for work and it is more difficult to take time off, although salaries are higher.

\subsubsection{Decision making}

Parents are significantly involved in the decision making of their daughters. Most WTE and WNTE reported that they lacked confidence to make a decision by themselves involving their personal life and education. They always asked for suggestions of what they should do and even asked for permission in order to go out from home. They perceived that parents understood life better than them, and parents were more mindful and anxious with the lives of daughters than of sons. In contrast, sons spend less time with parents and consult less on their current life and issues. Most issues concerning sons seem to be dealt with by themselves and spontaneously. Overall, most WTE and WNTE reported that males have more power on decision making than females. For example:

I am unable to make a decision by myself, particularly on my study. I consult with my parents in everything such as selection of school, faculty and course; how many institutions that I should apply to. Because all of the applications and examinations require some money and time. Some schools, they require many documents such as health checking documents, penalty notices; all of the documents require some money and are time consuming (WTE2).

\subsubsection{Current jobs and skills}

The majority of WNTE are not satisfied with their current life. Seven out of ten WNTE do not have permanent jobs, rather they work casually as grocery sellers, beauticians, dishwashers and farmers. Most WNTE lack skills and experience for their current work, particularly vendors and farmers. The venders said, for example, that they lack sales skills. They just follow what their mother and cousin did and suggested. Their shops are 
very basic and have few products. They emphasise that the daily sales and income are unstable, when some days they can earn less than 100,000 kip ( US\$12) ${ }^{3}$. For example:

Because I only graduated from a secondary school, I had to find a career to take care of my own life and I used to stay with my sister who is a vender. I got some experience from her. Thus, grocery selling is the only choice for me (WNTE6).

Figure 5.7: A small grocery shop

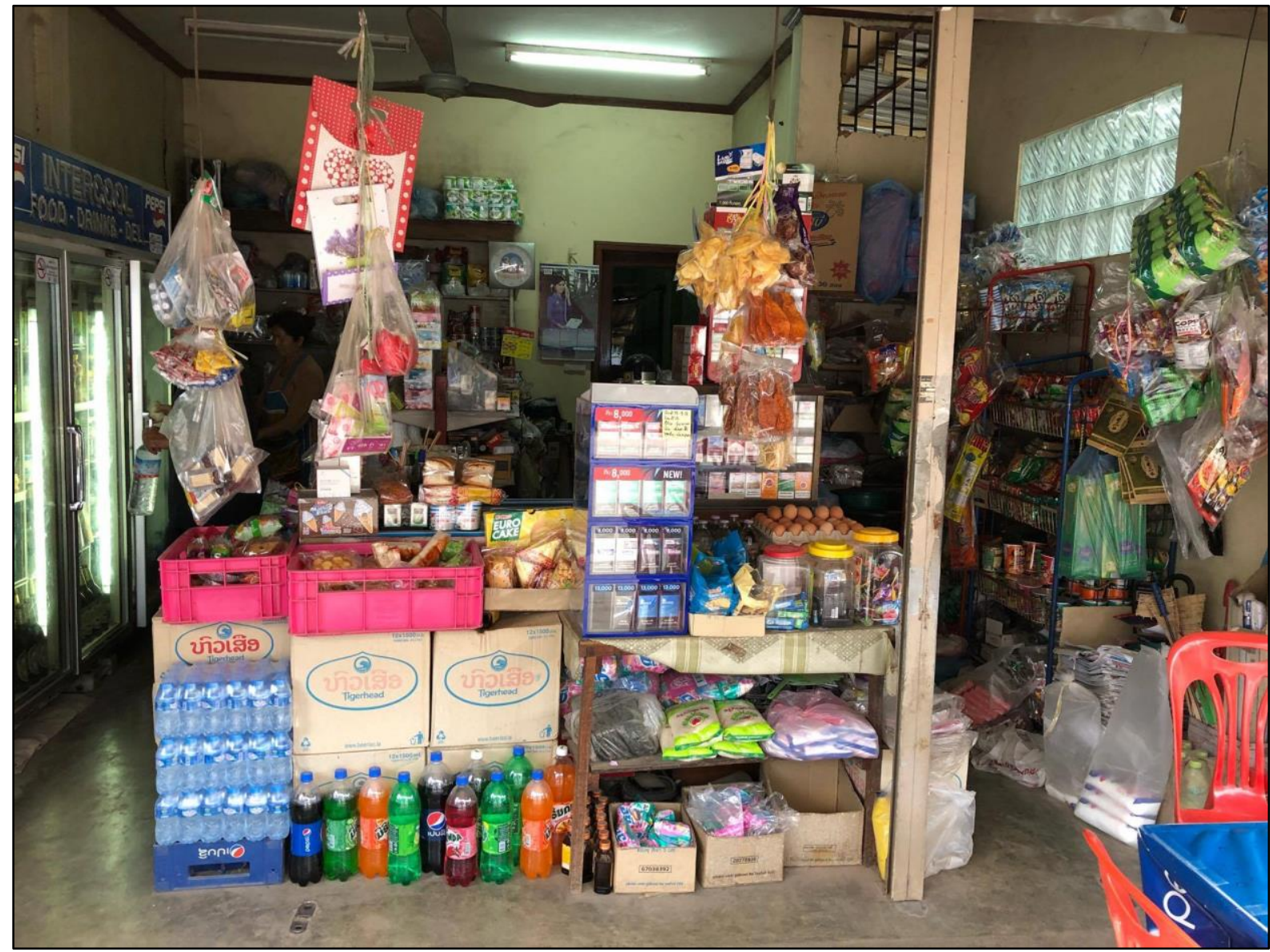

Location: Dongdok village, Xaythany district, Vientiane Capital, Laos

Only one out of the ten WNTE interviewed reported that she was quite satisfied with her current career. She was a beautician with her own shop. She could earn a satisfactory income of around 150,000 to 200,000 kip per day ( US\$12 to US\$24), even if it is not stable. She said her customers are quite satisfied with her services. She graduated in beauty training from the Youth Vocational Training Centre in Vientiane. With some skills and techniques from her training, she continued to develop her skills by herself, for

\footnotetext{
${ }^{3}$ Exchange rate 8,300kip/USD from the Bank of Laos in 2017, website: https://www.bol.gov.la/english/exchrate.html
} 
example practising new hair styles. At first, she hesitated to attend training because she wanted to study at a bachelor's degree level with the hope of working at a government office after graduation. Thus, she tried to take a few exams in NUOL and the Institution of Economic and Finance, but failed. Her mother then supported her to study about beauty in a TVET. She had studied for only eight months. She said that learning about beauty is not difficult, with focus on both academic and practical aspects.

Figure 5.8: A barber shop

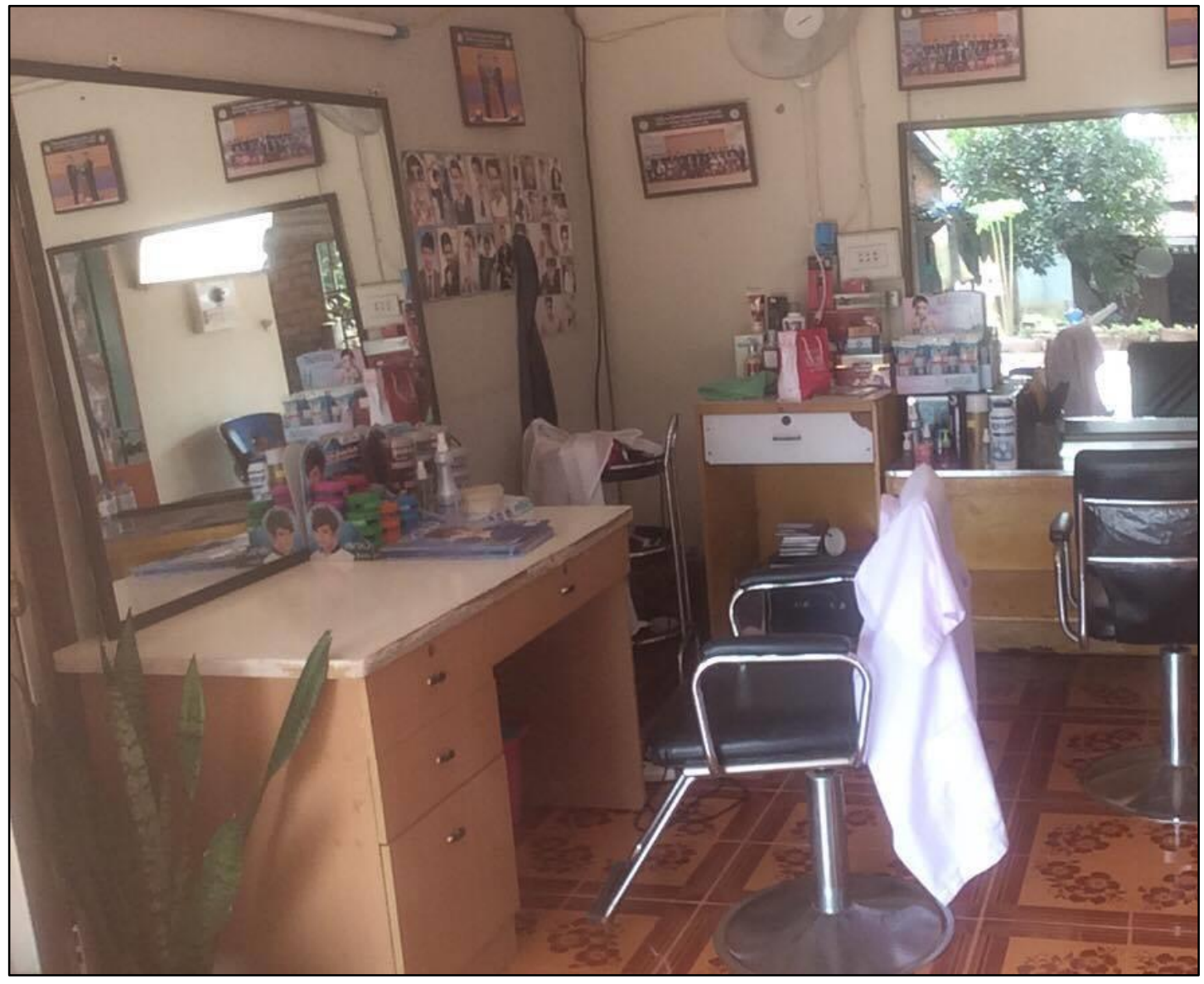

Location: Nasangphai village, Saysettha district, Vientiane Capital, Laos

The remaining three out of the ten WNTE have no job as they are as housewives with one or two children. Two of these participants said that they have to rely on their husband. One of participants was divorced. Thus, she relied on her mother and helped the mother by doing small household grocery sales. She relied on her sister who worked with a private company for survival. She stated that she has no skills to do another activity and lacked money for vocational training. She also had a small baby son, and hoped that her mother and sister might be able to support her son's education to a higher level than she could. 


\subsection{Social norms}

\subsubsection{A family caretaker}

Both WTE and WNTE were more likely to have a close relationship with family members and take care of parents than male counterparts. Women take charge of household management including food, health, education, cleaning, expenditure, and all family member's development. This is illustrated in their sacrifice in time and effort to do all the household chores. Most women participants said that they feel sympathy letting parents do household chores by themselves as parents have supported them in everything already. When the household confronts some difficulties such as insufficient income, for example, a female will try to earn some money in order to help the family. The research also found that when women realise that their parents cannot support their study, they mostly decide not to burden their family anymore by dropping out from school and earning money instead. For example:

I am studying in Vientiane-Hanoi Friendship Vocational School and I am also working in a restaurant as a dishwasher. My work is quite hard, I have to carry many dishes and big pans. My tiredness disappears when I get a salary and it is around 1,000,000kip ( US\$120.50). I can take care of my own expenditures and I help family by supporting my younger sister in her schooling (WNTE7)

I know that my family is poor. Therefore, I study in a university during the weekday and I do part-time jobs as a cleaner, housekeeper and gardener at weekends. I try to save money as much as I can every time that I get my wages and then I can totally be responsible for all my expenditure in the university. But my two brothers don't help us with household tasks. My older brother works as a soldier, but we still have to back him up (WTE1)

Not only do WNTE look to find a job or a career, WTE also look to find a job during their free time. For example, one WTE reported that she was doing online sales when she has free time. However, she felt that it occasionally disrupted her study. Despite that, doing online sales helped her to earn some money and she was able to take of her expenditures in the university. 


\subsubsection{Women and job opportunities}

Males and females are different in their body. It is obvious that males go beyond females in working life. However excellent or outstanding women are, they are less likely to go further than men. It is illustrated in that most leadership positions are majority male. In my class, a male student was a head of a class (WNTE1).

The above perception largely persists among women participants, particularly WTE who are currently studying and looking forward to a job in their near future. This perception can also somewhat impact the quality of learning. For instance, one WTE thought that males were better at study than females, with male students more likely to concentrate on learning than their female counterparts, while females are too shy and unconfident. Another WTE who was studying her fourth year at NUOL emphasised that she was quite worried about finding a job. She had heard that most private companies prefer males rather than females, especially in technical work (she was studying biology). She cited that most employers do not prefer females because females might take a long break for giving birth and are less able to work longer hours than males as females mostly have to take care of a family. Some WNTE think that males are more privileged than females as they can do hard work and in various working conditions, overall gaining more opportunities to get a job. One WNTE reported that her brother, an orphan like herself, can support himself to study at a university. He works as a labourer and saves more money than what she can as a gardener.

\subsubsection{Youth issues}

Early marriage is one obstacle for women's access to tertiary education. Three out of ten WNTE interviewed got married early after secondary school. They married when they were less than 18 years old and had children shortly after. They reported that it was hard to manage their own family and be a wife, given their youth. Young couples still mainly rely on their parents, but if it is necessary, they will try to find an income to support the family, for example through grocery selling or laboring. Despite the need for working, young participants understood the importance of future study. For example:

I want to work, but I still have a small baby. It is not easy to study and take care of a baby at the same time. But I want to study and my mum will give me money and she will help me to take care of my son during my study. Thus, I attended NUOL's examination. Presently, I am just waiting for an examination result. My 
husband also agrees. He also emphasises education and is currently studying at Faculty of Economics and Business Management, NUOL (WNTE4).

Drug addiction is one problem in Vientiane society, including for teenagers. One WNTE reported that she had been addicted and it had affected her study in secondary school. The quality of her learning has been poor since that time. She could not concentrate on learning at all and frequently missed classed. Even though she did not fail in the final examination in secondary education, she failed an entrance examination of NUOL. Currently, she has to work hard for her family's survival. She expressed regret and pity, realising that if she focused more on education her life would be better.

\subsubsection{Women and knowledge on gender equality}

The majority of female participants have a lack of awareness of gender equality issues. Some participants reported that they have heard about gender equality, but did not clearly understand what equality means in practice. Some female participants did not know at all. Some WTE reported that, in school, gender issues received some focus as teachers distributed some information regarding gender balance such as the importance of equal treatment, and equal tasks. However, some WNTE reported that a gender imbalance in schools still remains in practice. For example, female students had to take care of school cleaning. Another female student reported that men had more chances than women to be involved in outdoor activities. For example, male students were more likely to gain a chance to go into the field in a province to observe various kinds of trees in a forest, while female students had to stay in a village and wait for reports from male counterparts. Typical perceptions on gender balance were showcased by the following interview quote:

I rarely see the balance between males and females, most females are still under male control. It is shown as females have to do more household chores than male. In contrast, males are the majority in higher positions in workplaces (WTE5)

\subsection{Tertiary education}

\subsubsection{Tertiary education examination and enrollment}

There are various processes and required documents in HEI examination and enrollment. Newly graduated students from high schools prefer to take two or three examinations to ensure that they will get to at least one HEI. Before taking the exam there are some required documents that students have to prepare to register in a particular HEI entrance 
examination. For example, the NUOL application form for registration for an entrance examination has to be accompanied by a chosen programme and faculty document, an entrance card of a final exam of a high school, a graduation certificate from a high school, and a family book or an identification card (NUOL, 2017). Moreover, some HEIs can require a health check document and a punishment attestation, which both take time to process. The current fee for registration for an entrance examination for NUOL is 35,000kip ( US\$4.22) (ibid). Students also have to pay other HEIs examination registration fees.

I had to prepare many documents and felt tired and disheartened. I had to pay for an exam enrollment fee too, and I wonder that they allow students to take the exam, but only a quarter are admitted by the HEI. (WNTE1)

The entrance examinations into HEIs were reported as difficult by most female participants; the key reason why the majority of WNTE failed entrance examinations. Some WTE and WNTE cited that it was quite difficult to pass the examination into HEIs, especially public universities. Most WTE and WNTE are not familiar with the entrance examination.

In addition to hard entrance examinations, enrollment fees and other expenditures are the main obstacles for many medium-income and poor families. Some WTE and most WNTE reported that the HEI enrollment fee is quite high, particularly for private HEI. For example, for NUOL, a public HEI, the enrollment fee is around 1,200,000 to 1,500,000 kip ( $\sim$ US\$145 to US\$180) per year (Senior officer, NUOL). Moreover, in some private school enrollment fees are around 3,500,000 to 3,800,000 kip ( US\$420 to US\$460) per year (Senior officer, Rattana College). Compared to GDP per capita; US\$2,408 in 2016 (Lao Statistic Bureaus, 2017); the higher enrollment fee accounts for 7.5 percent in public HEIs and 19 percent in private HEIs. In addition, other fees such as resource materials, uniforms and transportation have to be considered by students and families. Therefore, it is no wonder why most of the poor cannot access HEIs. For example:

I could pass the examination of a programme in the Faculty of Engineering, NOUL, but I didn't have enough money to pay the enrollment fee before the due date. Hence, I decided to study in Vientiane-Hanoi Friendship Vocational School 
(public Technical Education and Vocational Training), which costs less than half compared to the HEI enrollment fee (WNTE7)

\subsubsection{Tertiary education policies for women}

Most HEIs have a lack of information dissemination campaigns related to the schools and offered programmes, particularly high-profile universities and colleges. Some wellknown HEIs believe that they have a good reputation, especially in the capital, and some public institutions report a lack of finance for marketing. Hence, WTE and WNTE have a lack of information and ideas about HEIs before taking an examination or enrolling. Furthermore, most HEIs, including private and public colleges and universities, have a lack of particular policies for women in order to increase the access of female students. Both public and private senior officers from HEIs report that their institutions treat male and females with equality in terms of access, in classes, and joining school activities and grades.

\subsection{Summary}

This chapter presented the main findings related to family characteristics, women's behaviours and preferences, and social norms. It found that a family is the foundation of a daughter's education, including in respect of budgets, resource materials, discipline, suggestions and consolation. This all combines to create the interest of children in education from an early age. However, low family economic status is the main obstacle for women's access to tertiary education. Within this category, participants decided to stop their study after secondary school to earn money by themselves. However, typical casual jobs and livelihoods pursued created low and unstable income and poor working conditions. In addition, women are the main providers of various household activities such as household chores, helping parents' businesses, and even earning some income to support other family members' education. Overall, many women sacrifice themselves by stopping learning.

In addition, parents and social norms still influence women's perceptions and interactions. Parents see women as more vulnerable than men, and they are less likely to allow young women to go out and enjoy social life as men typically do. Parents also prefer women to be at home preparing to be a good wife and a good mother rather than to be independent. Furthermore, social norms embed women as polite and gentle. They 
should respect the teachers and older people. However, this can lead to women who are less confident and less likely to make decisions by themselves.

The difficult examination and enrollment fees are some of the main obstacles for women's access to higher education. This combines with social norms restricting access to tertiary education. Most HEIs also lack specific policies around women's access to HEIs. 


\section{Chapter 6: Discussion: Women and tertiary education}

\subsection{Introduction}

Many barriers regarding women's access to tertiary education have been found during the field work and the reviewed documents (see chapter 5) and are discussed in this chapter. The sections below analyse the main obstacles such as financial hardship, imbalance in household chores, poor education and child rearing, career preferences and tertiary education institutions' lack of information dissemination, respectively. These findings will be compared with the literature review, relevant theories, and yield some recommendations.

\subsection{Family financial status}

"All we need for education is money - from paying the rent to the tuition fee" (Soukkaseum, 2017, p. 116). The study found that poverty is the main obstacle for women to access to tertiary education. The majority of WNTE families in the research are poor, with low paid jobs and unstable income. It is quite hard for the parents to support all children to study in HEIs which require significant cost. Parents have to meet the high enrollment fees, which account for 7.5 percent in public HEIs and 19 percent in private HEIs, as a proportion of the average GDP per capita in Laos in 2016 (Lao Statistics Bureau, 2017). As well as the enrollment fee, parents of WTE also take care of students' uniforms, tuition, educational materials, transportation, meals, and especially accommodation for their children's education. These expenditures have also been mentioned in the study on "schooling, poverty, and disadvantage in the Lao People's Democratic Republic" by King and van de Walle (2007). These expenditures are higher in the higher levels of education such as higher diplomas, bachelor's degrees and master's degrees.

Social feminist perspectives pay attention to women in the social division of labour in the family (Campbell \& Wasco, 2000). According to this perspective, the study found that women are responsible for household management. Women sacrifice their time and effort to do household tasks and take care of family members (Liamputtong, 2006). In addition, they are more likely to understand family issues and keen to help. Therefore, when women realise that their family faces financial difficulties, they are more likely to stop their education and turn to do other activities to gain income and help the family. 
Social feminist perspectives focus on the restricted opportunities for women to participate in the paid labour force as well as the patriarchal power base of the home (Blieszner, 1993). A family may consider supporting education for a potential student, but they have to draw on their limited incomes and savings such that a potential student will be someone who has good health, proven ability and is hard working, and who has more potential to find a good job and career advancement. Definitely, many families in Laos perceive these potentials more in sons than in daughters and thus they prefer to support sons rather than daughter for education (King \& van de Walle, 2007; Maertens, 2013). After marriage, many women in Laos expect to be as a housewife. This is seen to require less formal education (Maertens, 2013) and this view was highlighted by a respondent cited in the study of Soukkaseum (2017, p. 115): “you are a woman, you don't need to study, you just get married".

The study found that participants also depend on parents' decisions and women traditionally still stay close to their natal home (Krulfeld, 1994). This is viewed as an advantage for them as they may gain continuing assistance from their parents. Parents, on the other hand, perceive men as heads of households and income earners (Anderson \& Lee, 2005; Soukkaseum, 2017), as well as men traditionally have to move to a wife's family house or to a new house (Cooper, 2011). Men rarely gain help from their natal parents. Therefore, parents bring up a man to be accountable, independent, and to be able to take care of himself and his own family. Hence, parents are more likely to support men in education than women.

The Government of Laos has a quota system for every province to ensure that students from ethnic minority groups gain access to higher education (Chapman \& Austin, 2002). Even though there is this quite explicit ethnic quota from the Government of Laos, there is a lack of specific quota for the poor and for women. Furthermore, in Laos, presently, there is no student loan scheme with low interest from either public or private banks. Many developing countries have student loans to assist students who intend to study, but have only a limited budget to support themselves (Albrecht \& Ziderman, 1991). Therefore, if a family is poor in Laos, women are less likely to have the opportunity to study in high cost HEIs. From the perspective of socialist feminist theory, then, we can see that gender inequalities and poverty are reproduced in a context where market mechanisms determine the costs of higher education. 


\subsection{Household chores and poor study discipline (family roles)}

Radical feminists focus on the power imbalance between men and women, as women tend to have less power than men. Women have to be responsible for household chores that provide them with less to spend on their schooling (Stromquist, 1989). The study also found that most female participants have to take care of household tasks with little or no help from male siblings. They spend at least one hour a day on household tasks and it might be longer at the weekends. King and van de Walle (2007) found that poor rural girls spend fewer hours in school than working, (the average was 5.3 hours a day working). The larger the family is, the more burdensome household tasks are for women. Female participants in this research, as with women in the Third World, have a strong perception that household tasks are female duties (Momsen, 1991). Some female participants are less likely to realise that household tasks are burdening their social life and creating some negative impact on their study. Conversely, families of WTE seem to have more of an even share of household tasks between male and female siblings and suitable time management compared to families of WNTE. This can create an advantage for WTE to have more chances to get involved in various school activities rather than doing cleaning, cooking and washing repeatedly every day. The time spent on household chores can impact on education and quality of female students, as Rogers's study on "Cambodian young women's education, identities and rights" found that household responsibilities are the most significant factor in Cambodian girls dropping out of school (Rogers, 2014). The balance in the family is important and it can be started in childhood (Terry, 2007). It can be initiated by parents to encourage both male and female siblings to get involved in doing household chores. Then male and female siblings can have balanced time on study, work and to enjoy a social life and also create solidarity among siblings.

A lack of study discipline also influences efficient education. Parental supports and encouragement is important and a perception of the important of education can be started in early childhood. The more parents focus on education, the more children will succeed in education. The research found that more than half of parents of WTE have focused on children's education. The parents have supported girls through material resources, suggestions and consultation. Some parents are furthermore able to provide technical knowledge which is relevant for, and of benefit to, their children's academic courses. When parents emphasise education, the children will like to study and be keen to spend their time and efforts on learning. They are then equipped with knowledge and prepared 
for difficult examinations. These also depend on parents and the research also found that most parents of WTE have high economic status and educated parents are aware of and concentrate more on a child's discipline.

Another significant finding is that many women participants appear to be powerless. They have to rely on parents' decisions and obey what parents decide for them. This lack of power in decision making may impact their life as parents' decisions may not be appropriate for women. These align with the study from Malik and Courtney (2011) on women in Pakistan which found that women lack both the confidence and the expertise to put themselves forward in social situations and their lives are governed by their family. Empowering women in Laos is a goal of the Government of Laos and non-governmental organisations. Therefore, we can see that the way women's and girls' roles and aspirations are shaped within families, and by parental attitudes, are vital in determining participation in higher education. This is partially in line with radical feminist theory, in the way radical feminism perceives patriarchy to operate, but it seems to be shaped by broader and more diverse patterns of family attitudes regarding girls' domestic work and study.

\subsection{Work preferences and opportunities (social norms)}

Social feminist perspectives also call attention to the social division of labour in the workplace (Campbell \& Wasco, 2000). The social perception of women's work opportunities influences decisions regarding education. The study found that most women prefer to continue their education through higher education qualifications. However, some of them are worried about the difficulty of gaining a job. Many Lao women still perceive that women are less likely to gain a job than men. Even though women's education has slightly improved (Entmacher, 2014), their positions and salaries are still lower than men, when they do get jobs (Buvinic et al., 1984; Entmacher, 2014; Momsen, 1991; UNDP, 2015). This finding aligns with the study by David (2017, p. 21) that "a better level of education doesn't necessarily translate into better employment opportunities. Even though women outperform men in education, they still face significant shortfalls and discrimination in the labour market and end up in jobs where they don't use any of their skills". A UNDP report in 2015 states that the majority of senior civil servants and professionals are men (UNDP, 2015). Moreover, men are more likely to be favoured in the wage structure than their female counterparts (King \& Hill, 1993). This social norm can cause women and their parents to hesitate to decide to proceed to education at higher levels, as they still perceive that women are less likely to 
gain a job after graduation, and are more likely to hold lower positions and gain lower salaries than men.

Graduation from tertiary education may not guarantee gaining a job. The number of enrolled students in HEIs in Laos has dramatically increased since 1996, since the establishment of NUOL (NOUL, 2017) and the percentage of women in education has nearly reached the government's goal (MoES, 2015). However, the high quantity does not mean a high quality of graduate students. The curricula of HEIs are out of date and do not align with the labour market in Laos (Siharath, 2010). There are many graduates from HEIs who remain unemployed (MoES, 2015). Some of them end up in selfemployment such as household grocery stores, and/or small restaurants, especially female students. Therefore, their livelihoods are not significantly different between before and after they graduate from HEIs. This perspective influences some parents and students. They perceive less value in quality of HEIs and they decide not to study because of the high cost and poor quality of education and uncertainly in gaining job after graduation.

In addition, some HEIs in Laos are less likely to co-operate with employers, institutions and companies in order to ensure their graduate students find jobs. In response to the issue of the low quality of HEIs, the Government of Laos enacted an amendment to the Higher Education Reforms in 2011 (Senior officer, Department of Higher Education, MoES). The amendment in 2011 focused on improving curriculum, quality of teaching, management and services. The amendment ordered all private HEIs stop offering both bachelor and master degrees. Only five public Universities are allowed to offer both degrees. This led to a dramatic decrease in the number of students in private HEIs since 2011(Senior officer, Rattana College). Some HEIs were so affected that they had end their businesses.

Accordingly, study in TVET is another choice for women. A few participants in this research preferred to work and earn money directly after graduating from an upper secondary school, rather than spending time in at least three years' further education in HEIs and then face uncertainty gaining a job. They directly studied in a vocational training institution and are satisfied with their learning and skills from TVET and presently manage their own businesses. TVET seems to be more consistent with the demand of the labour market than HEIs (MoES, 2015; Soukkaseum, 2017). Studying at TVET was more flexible than at HEIs and students are able to do part-time jobs while 
studying. Taking part-time jobs allows students to earn additional income and reduce the burdensome expenditure of a family (Soukkaseum, 2017). Due to the short period of learning, low enrollment fees, and being equipped with practical skills (ibid), study in TVET seems to benefit poor and medium income women as they are more able to afford it and it is less likely to consume their time on study. Presently, UNDP reports that Lao women represent 64 percent of the elementary occupations including in the services, shops, and market sales workers (UNDP, 2015). The MoES have mentioned 'Developing a Curriculum' (DACUM) in the Master Plan Development of TVET from 2008 until 2015 and it is an approach to improving TVET curricula in which courses are to be based on the needs of industry (MoES, 2010), but TVET curricula have been reported to be poor (UNESCO, 2013).

\subsection{Tertiary education information dissemination and enrollment}

Liberal feminist perspectives focus on equal opportunities for women and men, including in education (Parpart et al., 2000). The study found that failing an entrance examination is one obstacle to accessing tertiary education. Most female participants prefer to study in public HEIs, due to the lower cost and better quality compared to private HEIs. However, the difficulty of entrance examinations and many processes of enrollment were mentioned by some participants. The limited places in public universities (Songkaeo \& Yeong, 2016), leads to high competition. This high competition requires a high level of preparation from students to pass the exam. Therefore, this impacts on women's access to these institutions as they have less time to prepare than men, as women also spend time on household chores, and therefore have less potential to pass the exam. This circumstance may impact poor women most, as they may not be able to afford to access private HEIs, due to the enrollment fee being more than two times higher than public HEIs.

Liberal feminist perspectives in education argue for the removal of barriers which prevent girls reaching their potential, whether such barriers are located in schools, the individual psyche or discriminatory labour practices (Acker, 1987). In this way, some ASEAN countries have considered the difficulty of entrance to HEIs. For example, the Cambodian Government has considered a flexible way for students to enter higher education, and also adjusted the curriculum of secondary education to contribute some knowledge that is fundamental to enter into HEIs (Songkaeo \& Yeong, 2016). However, the entrance examination to public HEIs in Laos have been reported to be harder as HEIs want to gain 
high quality students to study in their reputable institution (senior officer, NUOL). In addition, preparation courses for entrance examinations are only unofficially provided by teachers from NUOL in Vientiane Capital. Those who are in other provinces and far from NUOL's location have less chance to attend the courses.

Most public and private HEIs in Laos place little importance on marketing and information distribution. The lack of financial resources and knowledge of social marketing have been reported to be the main obstacles to launching these activities. Limited information on enrollment processes, course offerings, examination subjects and processes, enrollment fees and payments seem to impact students most. For example, this study found that most participants have limited information on courses being offered, and the qualifications and services of higher education institutions. Therefore, some participants reported that they selected courses according to other suggestions. As a result, they felt they performed poorly, wasted their time and were unsatisfied with the enrolled courses. Enrollment processes were also reported by some participants as complicated with complex requirements for various documents and being time consuming to complete. As well, the enrollment fees differ across HEIs and courses. Some parents and students presumed that enrollment fees would be too expensive. This led them to make decisions without gaining accurate information.

The Government of Laos has policies on women having equal access to all levels of schooling (MoES, 2008c) and strategies have been put in place to deal with issues regarding gender inequality in schooling (Edwards \& Girgis, 2015). They have emphasised primary and secondary education (Ogawa, 2009). As well as, public quotas are offered to ethnic minorities groups (ibid). However, HEIs' policies on women's regarding access to tertiary education seem to have been left out of these national initiatives in practice.

\subsection{Summary}

This chapter discusses the main findings on women's access to tertiary education in respect of family characteristics, women's individual preferences and behaviours, and social norms. Financial hardship of their families is the main obstacle. Shortage of income may lead parents to support men rather than women. Women are also keen to respond to the issue of the needs of their families and may dropout where they perceive enrollment fees are burdening them. On the other hand, the Government of Laos lacks policies for 
women in relation to access to HEIs and there is no student loan provided by any public and private banks. Definitely, poor women cannot afford to attend HEIs.

Women have less power in the family. They are labour in a family and they have to spend time on household chores. They have less time than men do for study as well as social life. Women have less power in decision making for themselves. They have to consult and follow what parents and siblings suggestion, including with regard to marriage, work and study. This leads women to be dependent on parents, and lack confidence to survive by themselves, if they do not have a husband to rely on.

Such social perceptions still affect women's and parents' decisions. The perceptions of employment opportunities for women, including of the difficulty in gaining jobs, likely lower positions, and lower payment than men, existing in Lao society may influence women not to study at higher levels. Most women end up in self-employment with small businesses such as barbershops, small groceries, restaurants, and as laborers with low and unstable incomes, and poor working conditions.

The enrollment process is still difficult for normal citizens in Laos. On the one hand, the lack of confidence of many women in the quality of their study to-date leaves most students feeling they are not well for the examinations, and this leads to high potential of failure. On the other hand, the lack of information about the courses and entry examinations provided by public and private HEIs reduces the number of students who are able to be well prepared for the examinations. 


\section{Chapter 7: Conclusion}

\subsection{Findings and reflections}

This thesis is about women's access to tertiary education in Laos. It examines the barriers which most influence women's access to tertiary education. The scope of the thesis focuses on family characteristics, women's preferences and behavior and social norms, by using a feminist lens to analyse the main issues.

The main influence on women's access to tertiary education is parents' economic status - that is, poverty. Because both private and public HEIs require students to pay an enrollment fee and other expenses such as material resources and uniforms, most parents may prefer to support sons rather than daughters to study, as they perceive men are more likely to gain a job and to be a head of a family. They believe most women can rely on their husband for income earning and women should take care of a husband, household and children. Hence, parents see education for women as a second priority. The Government and HEIs lack policies or funding for women, particularly for those with the least access - women from poor families. Even though most countries in the ASEAN region provide student loans for students who are keen to study, but lack funds to study, the Government of Laos has not yet applied such a policy.

Another finding relates to gender imbalance within a family. Most female participants in the study have to take care of household chores, while most male students seem to have more time to enjoy an active social life than female students. The longer women stay at home, the less time they spend in wider society. This may cause women to lack confidence and have less power to manage their lives. Most decisions regarding study, work and marriage are made by parents. Parents seem to control daughters more than their sons: they are less likely to allow women to go out at night and worry about early relationships with men. This gender imbalance issue in households has a circular effect. It starts with the view that women should work at home, not enjoy social activities, they then become less confident, less engaged and successful in education, have less opportunity to gain a job and be independent, have less power in a family, and finally end up as a housewife. Reversing this cycle can start with a family, for example by letting a daughter and a son both be involved equally in household chores and social activities.

The social perception of the low qualification of women still persists in Lao society. Even though the percentage of women in all educational levels increases, the potential of 
women gaining a job does not increase, accordingly. Women represent the majority in the proportion of people in unemployment and low wage jobs. This influences some women not to study and to choose to directly work as labourers, as they perceive that there is no gain between before and after they graduate from HEIs, as they will earn a lower income payment and work in lower-level positions than men. The Government of Laos emphasises balanced opportunities between men and women in working in both public and private offices; however, women are less likely to be in leadership positions and therefore will have less power in decision making.

Low quality of tertiary education may influence the decisions of women and parents. Tertiary education in Laos needs to be improved in quality of learning and teaching. The out of date curriculum and mismatched programme with the labour market, lead newly graduated secondary to hesitate to enroll in tertiary education. The difficulty of an entrance examination has been reported by most women participants, particularly public HEIs. This affects the low and medium quality study most. Many HEIs should be more flexible for admission new students, in order to increase the number of students and give more chance to the medium quality students.

Both public and private HEIs lack a marketing campaign. Most female participants reported they had limited information on HEIs, including about enrollment and course offerings. This may lead to less interest from students to enter in any HEIs. A marketing campaign will be beneficial to both HEIs and students. The HEIs will promote the quality of the institution and its courses quality for students. At the same time, students will know about a particular HEI and they may select that institution first.

\subsection{Limitations and future research}

There are many women in rural areas who cannot access higher education, according to discussions with senior staff working in relevant to HEIs. They generally mentioned that poverty, cultures and distance are the main obstacles for women. Unfortunately, I as a beginning researcher have limited scope and time to explore these barriers and how they impact livelihoods and the development of women in rural areas, including in minority groups, in accessing tertiary education.

The research was broad in scope as it deals with the issues related to tertiary education, whereas there are different levels of tertiary education including higher diploma and 
bachelor's degree. The conditions for student admission also vary between public and private HEIs. Hence, it would be clearer and more comprehensive for future study to focus on the specific education level within public and private HEIs.

The research focuses on women and parents, meaning focus on individual and social norms rather than at policy level. Therefore, most information reported and analysised focuses on individual feelings, experiences and perspectives. It lacks analysis of policies of government and private HEIs related to women's access to tertiary education.

Interestingly, female participants are concerned about job opportunities. Most of them feel that men have more opportunities to gain a job and a higher position and get higher pay than women. Therefore, it is interesting to explore whether this perception is true and its causes and consequences.

\subsection{Final remarks}

This research applied three feminist perspectives including radical, socialist and liberal feminist perspectives. These helped the researcher to frame the research questions and inform the analysis. Liberal feminist perspective focus on policies for equal opportunities for both male and female students in access to schooling. This perspective in the research helps to consider education policies regarding to education in general and higher education. The research found that there are policies to encourage women to access into all levels of education, from primary, secondary, TVET and higher education, yet in practice, the Government of Laos puts more focus on women's access to primary and secondary education, and TVET rather than higher education.

A socialist feminist perspective focuses on social divisions in a family and workplaces and particularly on the role of capitalism in shaping different focus of work and rewards for men and women. The research however illustrates that imbalance in the workforce starts from attitudes and decisions with the family. Currently, parents and women themselves still see female siblings primary as labour at home to manage most household tasks. On the other hand, it is also clear that in the labour market, women struggle to gain employment and equal wages and this effects their decisions regarding higher education and subsequent job prospects. 
The radical feminist perspective focuses on power imbalances between men and women in families and the role of patriarchy. Informed by this perspective, the research confirms that women have less power than men in a families and that women have to follow their parents' decision and work for male siblings and other family members. Most participants perceived that household chores still remain women's responsibility and that men take the lead in work outside the home. Therefore, such attitudes and patriarchal societal norms still exist in Lao society, even in Vientiane.

The thesis reconfirms that financial hardship impacts on parents' decisions regarding their children's education and women are more negatively affected by this issue, as they are placed as the second priority for parents for educational support. Furthermore, social norms on women with regard to household chores, politeness, and obedience, combine with the fact that women are less likely to gain a job and more likely to get low pay. These attitudes and conditions still persist in Vientiane society and affect women's participation in higher education. Suspicious of the quality of HEIs, many women chose to study in TVET institutions instead. Lack of information about HEIs and difficulty in preparing for the entrance examinations, further lessen the likelihood of participation. Although there are some promising signs of increasing participation by women in higher education, this research found that both deep-seated social attitudes and financial and institutional barriers are likely to combine to make it difficult for women from poor and rural households in Laos to enter higher education 


\section{References}

Acker, S. (1987). Feminist theory and the study of gender and education. International Review of Education, 33(4), 419-435. doi:10.1007/BF00615157

ADB. (2004). Lao PDR, gender, poverty and the MDGs. Retrieved from https://www.adb.org/sites/default/files/institutional-document/32234/cgawomen-lao-pdr.pdf

ADB. (2012). Improving transitions from school to university to workplace. Retrieved from https://www.adb.org/sites/default/files/publication/29968/improving$\underline{\text { transitions-school-university-workplace.pdf }}$

ADB. (2017). Asian development outlook 2017, Transcending the middle-income challenge. Retrieved from

https://www.adb.org/sites/default/files/publication/237761/ado-2017.pdf

ADB \& World Bank. (2013). Country gender assessment for Lao PDR: Reducing vulnerability and increasing opportunity. Retrieved from https://www.adb.org/sites/default/files/institutional-document/33755/files/caglao-pdr.pdf

Albrecht, D., \& Ziderman, A. (1991). Deferred cost recovery for higher education: Student loan programs in developing countries. Retrieved from http://www.nyu.edu/classes/jepsen/albrechtNov91.pdf

Allen, K. R., \& Jaramillo-Sierra, A. L. (2015). Feminist theory and research on family relationships: Pluralism and complexity. Sex Roles, 73(3-4), 93-99. doi:10.1007/s 11199-015-0527-4

Anderson, E. (1995). Feminist epistemology: An interpretation and a defense. Hypatia, 10(3), 50-84. doi:10.1007/s11199-015-0527-4

Anderson, W. W., \& Lee, R. G. (2005). Displacements and diasporas: Asians in the Americas. New Jersey: Rutgers University Press.

Anwar, S., \& Nguyen, L. P. (2010). Foreign direct investment and economic growth in Vietnam. Asia Pacific Business Review, 16(1-2), 183-202. doi:10.1080/10438590802511031

Ashton, D. N., \& Sung, J. (1997). Education, skill information and economic development: The Singaporean approach. In A. H. Halsey, H. Lauder, P. Brown, \& A. S. Wells (Eds.), Education: Culture, economy and society (pp. 207-218). Oxford: Oxford University Press.

Babcock, L., \& Laschever, S. (2003). Women don't ask: Negotiation and the gender divide. New Jersey: Princeton University Press.

Bailey, J. (2008). First steps in qualitative data analysis: Transcribing. Family Practice, 25(2), 127-131. doi:10.1093/fampra/cmn003 
Bauman, Z., Beck, U., Beck-Gernsheim, E., Benhabib, S., Burgess, R. G., Chamberlain, M., .. S Solberg, A. (2002). Qualitative research in action. In T. May (Ed.), Qualitative research in action (pp. 226-241). London: SAGE Publications.

Beckett, P. A., \& O'Connell, J. (1976). Education and the situation of women:

Background and attitudes of Christian and Muslim female students at a Nigerian university. Cultures et Developpement, 8(2), 242-265. Retrieved from https://www.africabib.org/rec.php?RID=191667641

Berniell, M., \& Sánchez-Páramo, C. (2011). Overview of time use data used for the analysis of gender differences in time use patterns. Paper presented at the the WDR 2012.

Blieszner, R. (1993). A socialist-feminist perspective on widowhood. Journal of Aging Studies, 7(2), 171-182. doi:10.1016/0890-4065(93)90032-F

Boserup, E. (1970). Women's role in economic development. London: Allen \& Unwin.

Bourdet, Y. (2001). Strengthening higher education and research in Laos. Retrieved from https://www.sida.se/contentassets/75fb5e5e8ca74c52bd5fc2f70749718b/13170. pdf

Burrell, B. C. (1996). A woman's place is in the house: Campaigning for congress in the feminist era. Michigan: University of Michigan Press.

Buvinic, M. L., Lycette, M. A., \& McGreevey, W. P. (1984). Women and poverty in the Third World. Baltimore: The Johns Hopkins University Press.

Campbell, R., \& Wasco, S. M. (2000). Feminist approaches to social science: Epistemological and methodological tenets. American Journal of Community Psychology, 28(6), 773-791. Retrieved from https://link.springer.com/article/10.1023/A:1005159716099

Carin Info International Edition. (2010). District of Vientiane Municipality, Lao PDR. Retrieved from https://www.cairn.info/revue-annales-de-geographie-2010-1page-120.htm

Castells, M. (1994). The university system: Engine of development in the new world economy. In J. Salmi \& A. M. Verspoor (Eds.), Revitalizing higher education (pp. 14-40). Oxford: Pergamon.

Chapman, D. W., \& Austin, A. E. (2002). Higher education in the developing world: Changing contexts and institutional responses. California: Greenwood Publishing Group.

Cheng, C. (2014). Why we need more women in parliament. Retrieved from https://christinescottcheng.wordpress.com/publications/women-inpolitics/mixed-member-proportional-leads-to-more-women-mps/why-we-needmore-women-in-parliament/

Cohen, N., \& Arieli, T. (2011). Field research in conflict environments: Methodological challenges and snowball sampling. Journal of Peace Research, 48(4), 423-435. Retrieved from http://www.jstor.org/stable/23035205 
Coleman, J. S. (1988). Social capital in the creation of human capital. American Journal of Sociology, 94, 95-120. Retrieved from http://www.jstor.org/stable/2780243

Conrad, C., Haworth, J. G., \& Lattuca, L. R. (2001). Qualitative research in higher education: Expanding perspectives (2nd ed.). London: Pearson Custom Publishing.

Cooper, R. (2011). Culture shock Laos: A survival guide to customs and etiquette (2nd ed.). Singapore: Marshall Cavendish International Asia.

Creswell, J. W. (2013). Qualitative inquiry and research design: Choosing among five approaches (3rd ed.). Los Angeles: SAGE Publications.

Dana, L. P. (1995). Small business in a non-entrepreneurial society: The case of the Lao People's Democratic Republic (Laos). Journal of Small Business Management, 33(3), 95. Retrieved from https://www.questia.com/library/journal/1G1$\underline{17438238 / \text { small-business-in-a-non-entrepreneurial-society-the }}$

DaVanzo, J., \& Lee, L. P. D. (1978). The compatibility of work and child care: Preliminary evidence from Malaysia data. Paper presented at the Women in Poverty: What Do We Know?, Belmont Conference Center.

David, M. E. (2017). Women and gender equality in higher education? The changing role of women in higher education (pp. 209-225). New York: Springer International Publishing

Davidson, C., \& Tolich, M. (2003). Social science research in New Zealand: Many paths to understanding (2nd ed.). New Jersey: Pearson Prentice Hall.

Department of State. (2015). Laos 2015 international religious freedom report. Retrieved from https://www.state.gov/documents/organization/256329.pdf

Desai, V., \& Potter, R. B. (2006). Doing development research. London: Sage Publications.

Dorner, D. G., \& Gorman, G. E. (2011). Contextual factors affecting learning in Laos and the implications for information literacy education. Information Research: An International Electronic Journal, 16(2), 1-23. Retrieved from http://www.informationr.net/ir/16-2/paper479.html

Duflo, E. (2012). Women empowerment and economic development. Journal of Economic Literature, 50(4), 1051-1079. doi:10.1257/jel.50.4.1051

Edwards, J., \& Girgis, M. (2015). Practical lessons from gender audit of an education sector plan in Lao PDR. Development in Practice, 25(5), 747-753. doi:10.1080/09614524.2015.1045447

Emadzadeh, M. (2003). The importance of capital investment in women's education. Women's Studies, 1(7), 115-140.

Enfield, N. (2006). Laos-language situation. Encyclopedia of Language and Linguistics, 6, 698-700. doi:10.1016/B0-08-044854-2/01693-X 
Entmacher, J. (2014). Women in low-wage jobs are underpaid and overloaded. Retrieved from https://www.theatlantic.com/politics/archive/2014/07/women-inlow-wage-jobs-are-underpaid-and-overloaded/431166/

Fox, C. (2003). No place for girls? Gender, ethnicity and citizenship education in the Lao People's Democratic Republic. Compare: A Journal of Comparative and International Education, 33(3), 401-412. doi:10.1080/0305792032000107830

Gajaseni, N. (2015). Trends and challenges in ASEAN higher education towards ASEAN integration. Retrieved from http://aei.aeiasc.edu.my/publication/trends-and-challenges-in-asean-higher-educationtowards-asean-integration/ - content

Gopinathan, S., \& Kam, H. W. (2000). Educational change and development in Singapore. In T. Townsend \& Y. C. Cheng (Eds.), Educational change and development in the Asia Pacific: Challenges for the future Lisse: Swets and Zeitlinger

Greenhalgh, S. (1985). Sexual stratification: The other side of "Growth with equity" in East Asia Population and Development Review, 2(11), 265-314. doi:10.2307/1973489

Gupta, V. (2014). Women empowerment through education. International Journal of Advanced Research Management and Social Sciences, 3(12), 231-238. Retrieved from http://garph.co.uk/IJARMSS/Dec2014/18.pdf

Hadjar, A., \& Schlapbach, F. (2008). Educational expansion and interest in politics in temporal and cross-cultural perspective: A comparison of West Germany and Switzerland. European Sociological Review., 25(3), 271-286. doi:10.1093/esr/jcn047

Hallinger, P. (2010). Making education reform happen: Is there an 'Asian'way? School Leadership and Management, 30(5), 401-418. doi:10.1080/13632434.2010.502524

Haque, M. (2005). Discrimination starts at home: A brief on parents' aspirations for adolescents and youth in Pakistan. Retrieved from https://www.popline.org/node/265615

Hermalin, A. I., Seltzer, J. A., \& Lin, C.-H. (1982). Transitions in the effect of family size on female educational attainment: The case of Taiwan. Comparative Education Review, 26(2), 254-270. Retrieved from www.jstor.org/stable/1187455

Heuser, B. L. (2007). Academic social cohesion within higher education. Prospects, 37(3), 293-303. doi:10.1007/s11125-008-9036-3

Hirschman, C., \& Loi, V. M. (1996). Family and household structure in Vietnam: Some glimpses from a recent survey. Pacific Affairs, 69(2), 229-249.

doi:10.2307/2760726

Htun, M. N. (2003). Women and democracy. In J. I. Dominguez \& M. Shifter (Eds.), Constructing democratic governance in Latin America (2nd ed.). Baltimore: The John Hopkins University Press. 
Ilie, S., \& Rose, P. (2016). Is equal access to higher education in South Asia and subSaharan Africa achievable by 2030? Higher Education, 72(4), 435-455. doi:10.1007/s 10734-016-0039-3

ILO. (2017a). Decent work country programme for Lao PDR 2017-2021. Retrieved from http://www.la.one.un.org/images/publications/ILO/lao_preview.pdf

ILO. (2017b). World employment social outlook: Trends 2017. Retrieved from http://www.ilo.org/wcmsp5/groups/public/---dgreports/---dcomm/--publ/documents/publication/wcms_541211.pdf

Jacobs, J. A. (1996). Gender inequality and higher education. Annual Review of Sociology, 22(1), 153-185. Retrieved from http://www.jstor.org/stable/2083428

Johnston, J. (2010). Qualitative research methods. Radiologic Technology, 82(2), 188189. Retrieved from http://www.radiologictechnology.org/content/82/2/188.extract

Kam, C. D., \& Palmer, C. L. (2008). Reconsidering the effects of education on political participation. The Journal of Politics, 70(3), 612-631. doi:10.1017/s0022381608080651

Kim, M. (2000). Women paid low wages: Who they are and where they work. Monthly Labour Review, 123(9), 26-30. Retrieved from https://stats.bls.gov/opub/mlr/2000/09/art3full.pdf

King, E. M., \& Hill, M. A. (1993). Women's education in developing countries. Baltimore: The World Bank.

King, E. M., \& van de Walle, D. (2007). Schooling, poverty, and disadvantage in the Lao People's Democratic Republic. Retrieved from http://paa2007.princeton.edu/papers/71259

Krulfeld, R. M. (1994). Reconstructing lives, recapturing meaning: Refugee identity, gender, and culture change. Washington DC: Taylor \& Francis.

Kumar, R. (2011). Research methodology: A step-by-step guide for beginners (3rd ed.). Los Angeles: SAGE Publications.

Kung, L. (1981). Perceptions of work among factory women. In A. E. M \& G. Hill (Eds.), The anthropology of Taiwanese society (pp. 184-211). Standford: Standford University Press.

Kung, L. (1983). Factory women in Taiwan. Michigan: University of Michigan Press.

Lao PDR. (1989). Lao PDR's report. The Government of Lao PDR. Vientiane, Laos.

Lao PDR. (1990). Family law. Retrieved from

https://www.mfa.gov.sg/content/dam/mfa/images/om/vientiane/Lao Law/Family Law.pdf

Lao PDR. (1991). The constitution of the Lao People's Democratic Republic.

Retrieved from http://confinder.richmond.edu/admin/docs/laos.pdf. 
Lao PDR. (2007). Law on education. Retrieved from http://ilp.gov.la/Laws_in_Lao/46.pdf.

Lao Statistics Bureau. (2016). Results of population and housing census 2015. Retrieved from http://lao.unfpa.org/en/publications/results-population-andhousing-census-2015-english-version.

Lao Statistics Bureau. (2017). GDP per capital in US\$. Retrieved from http://www.lsb.gov.la/lsb/en/ - .WgrulBOCw_U

Lao Women's Union. (2017). Lao women Retrieved from http://www.laowomenunion.org.la/index.php/la/)

Laos Demographics Profile. (2017). Laos demographics profile 2017. Retrieved from https://www.indexmundi.com/laos/demographics_profile.html

Laos Sūn Kānsathiti hǣng Sāt. (1997). Lao census 1995: Country report. Retrieved from https://books.google.co.nz/books?id=yK4UAQAAMAAJ

Leigh, J. P. (2001). Education and development: Measuring the social benefits. Economics of Education Review, 20(6), 612-613. doi:10.1016/S02727757(01)00022-X

Liamputtong, P. (2006). Motherhood and "moral career": Discourses of good motherhood among Southeast Asian immigrant women in Australia. Qualitative Sociology, 29(1), 25-53. doi:10.1007/s11133-005-9006-5 Retrieved from https://doi.org/10.1007/s11133-005-9006-5

Madge, C. (1997). The ethics of research in the 'Third World'. In E. Robson \& K. Willis (Eds.), Postgraduate fieldwork in developing areas: A rough guide (pp. 113-124). London: Royal Geographical Society.

Maertens, A. (2013). Social norms and aspirations: Age of marriage and education in rural India. World Development, 47, 1-15. doi:10.1016/j.worlddev.2013.01.027

Mahdavinejad, M., \& Moradchelleh, A. (2012). The impact of family and social class on efficiency of arts education and learning. Middle-East Journal of Scientific Research, 11(8), 1068-1077. Retrieved from https://www.researchgate.net/publication/267406100_The_Impact_of_Family_a nd_Social_Class_on_Efficiency_of_Arts_Education_and_Learning?enrichId=rg req-4ceedfb09e97578b886da50e5ef514e2-

$\underline{X X X \& \text { enrichSource }=Y 292 Z X J Q Y W d l O z I 2 N z Q w N j E w M D t B U z o y M z c x O T I x}$ NTI4NzUwMDIAMTQzMzU2MjQyNDA4OA\%3D\%3D\&el=1_x_3\&_esc=pub $\underline{\text { licationCoverPdf }}$

Malik, S., \& Courtney, K. (2011). Higher education and women's empowerment in Pakistan. Gender and Education, 23(1), 29-45. doi:10.1080/09540251003674071

Map of world website. (2015). Political map of Laos. Retrieved from https://www.mapsofworld.com/laos/laos-political-map.html 
McCowan, T. (2007). Expansion without equity: An analysis of current policy on access to higher education in Brazil. Higher Education, 53(5), 579-598. Retrieved from http://www.jstor.org/stable/29735074

MoES. (2008a). Education for all mid-decade assessment (EFAMDA): Lao country report. Retrieved from http://unesdoc.unesco.org/images/0022/002217/221788e.pdf

MoES. (2008b). Education law of Laos. Vientiane: Natioanal Assembly.

MoES. (2008c). Education sector development framework 2009-2015. Retrieved from http://moe.gov.la/data/publications/ESDF English version.pdf

MoES. (2010). Master plan development of TVET from 2008 until 2015. Vientiane: Ministry of Education and Sports.

MoES. (2011). Education sector development plan (ESDP) (2011-2015). Vientiane: Ministry of Education and Sports.

MoES. (2013). Mid-term review of the education sector development plan (ESDP) (2011-2015). Vientiane: Ministry of Education and Sports.

MoES. (2015). Education sector development framework (2016 - 2020). Vientiane: Ministry of Education and Sports.

Momsen, J. H. (1991). Women and development in the Third World. New York: Routledge.

MPI \& UNDP. (2009). Lao PDR: Employment and livelihoods (the 4th national human development report). Retrieved from http://hdr.undp.org/sites/default/files/lao_nhdr_2009_en.pdf

Muang Houn Secondary School. (2012). Education system in Laos. Retrieved from https://sites.google.com/site/hounsecondaryschool/about-us

Ngaosyvathn, M. (1990). Individual soul, national identity: The" Baci-Sou Khuan" of the Lao. Journal of Social Issues in Southeast Asia, 5(2), 283-307. Retrieved from http://www.jstor.org/stable/41056801

Ngaosyvathn, M. (1993). Lao women: Yesterday and today. Vientiane: State Publishing Enterprise.

NOUL. (2017). Background of National University of Laos. Retrieved from http://www.nuol.edu.la/index.php/en/about-nuol-4/2013-02-12-08-18-58/2013$\underline{02-12-07-57-13 . h t m l}$

Nussbaum, M. C. (2000). Women and human development: The capabilities approach. New York: Cambridge University Press.

Ogawa, K. (2009). Higher education in Lao PDR. In Y. Kitamura, Y. Hirosato, \& Y. Kitamura (Eds.), The political economy of educational reforms and capacity development in Southeast Asia (pp. 283-301). 
Onphanhdala, P., \& Suruga, T. (2006). Education and Earnings in Lao PDR: Regional and gender differences. Retrieved from http://www.research.kobe-u.ac.jp/gsicspublication/gwps/2006-04.pdf

Parpart, J. L., Connelly, P., \& Barriteau, E. (2000). Theoretical perspectives on gender and development. Otawa: International Development Research Centre.

Paxton, P., \& Kunovich, S. (2003). Women's political representation: The importance of ideology. Social Forces, 82(1), 87-113. doi:10.1353/sof.2003.0105

Phetsiriseng, I. (2009). Education reform context and process in Lao PDR: Focusing on basic education. In Y. Kitamura, Y. Hirosato, \& Y. Kitamura (Eds.), The political economy of educational reforms and capacity development in Southeast Asia (pp. 265-282).

Phommalangsy, P. (2013). An analysis of the influence of foreign aid on education policy in Laos. (Doctoral Dissertation ), The University of Queensland, Queensland.

Psacharopoulos, G., \& Woodhall, M. (1993). Education for development: Oxford University Press.

Rafiqui, P. S., \& Gentile, M. (2009). Vientiane. Cities, 26(1), 38-48. doi:10.1016/j.cities.2008.10.002

Rai, S. M. (2005). Equal participation of women and men in decision-making processes, with particular emphasis on political participation and leadership: Background paper. Retrieved from http://www.un.org/womenwatch/daw/egm/eql-men/FinalReport.pdf

Rehbein, B. (2007). Globalization, culture and society in Laos. New York: Routledge.

Rogers, A. V. (2014). Beyond university: Photovoice portraits of some Cambodian young women's education, identities, and rights. (Master's thesis), Victoria University of Wellington, Wellington.

Ropers-Huilman, R., \& Winters, K. T. (2011). Feminist research in higher education. The Journal of Higher Education, 82(6), 667-690. doi:10.1080/00221546.2011.11777223

Rossetto, K. R. (2014). Qualitative research interviews: Assessing the therapeutic value and challenges. Journal of Social and Personal Relationships, 31(4), 482-489. doi:10.1177/0265407514522892

SaengOuthay, O. (2015). The influence of Non-Governmental Organisations (NGOs) on primary education policy in Laos. (Master's thesis), Victoria University of Wellington, Wellington.

Saldana, J. (2011). Fundamentals of qualitative research. Oxford: Oxford University Press.

Scheyvens, R., \& Storey, D. (2003). Development fieldwork: A practical guide. London: SAGE Publications. 
Sharifi, A., Chiba, Y., Okamoto, K., Yokoyama, S., \& Murayama, A. (2014). Can master planning control and regulate urban growth in Vientiane, Laos?

Landscape and Urban Planning, 131, 1-13.

doi:10.1016/j.landurbplan.2014.07.014

Siharath, B. (2010). The higher education in Lao PDR and roles of international cooperation for its university development - National University of Laos. Retrieved from https://www2.gsid.nagoyau.ac.jp/blog/anda/files/2010/06/19 bounheng-siharath.pdf

Skelton, C., Francis, B., \& Smulyan, L. (2006). The SAGE handbook of gender and education. London: SAGE Publications.

Songkaeo, T., \& Yeong, L. H. (2016). Defining higher education issues and challenges in Southeast Asia/ASEAN within the international context. Retrieved from http://www.headfoundation.org/papers/2016_-

2)_Defining_Higher_Education_Issues_and_Challenges_in_Southeast_AsiaAS EAN_within_the_International_Context.pdf

Soukkaseum, P. (2017). The relevance of vocational education to the livelihoods of rural youth, Luang Prabang province. (Master's thesis), Victoria University of Wellington, Wellington.

Stromquist, N. P. (1989). Determinants of educational participation and achievement of women in the third world: A review of the evidence and a theoretical critique. Review of Educational Research, 59(2), 143-183. doi:10.3102/00346543059002143

Stuart-Fox, M., \& Bucknell, R. (1982). Politicization of the Buddhist Sangha in Laos. Journal of Southeast Asian Studies, 13(1), 60-80. Retrieved from http://www.jstor.org/stable/20070471

Sultana, F. (2015). Reflexivity, positionality and participatory ethics: Negotiating fieldwork dilemmas in international research. ACME: An International Journal for Critical Geographies, 6(3), 374-385. Retrieved from https://www.acmejournal.org/index.php/acme/article/view/786/645

Sutherland, M. (1988). Women in higher education: Effects of crises and change. Higher Education, 17(5), 479-490. doi:10.1007/bf00130541

Swamy, A., Knack, S., Lee, Y., \& Azfar, O. (2001). Gender and corruption. Journal of Development Economics, 64(1), 25-55. doi:10.1016/S0304-3878(00)00123-1

Symaco, L. P. (2013). Education in South-East Asia. Oxford: Bloomsbury Publishing.

Takita, S. (2010). Structural changes of higher education in transitional economies in LDCs: A case study of Lao PDR from the 'NEM' period onward. Proceedings, 9, 27-35. Retrieved from http://133.65.151.33/ocha/bitstream/10083/51385/1/Proceedings09_04Takita.pd $\underline{f}$

Terry, G. (2007). Women's rights. Oxford: Pluto Press. 
Tilak, J. B. (2001). Building human capital in East Asia: What others can learn. Washington: World Bank Institute.

Tilak, J. B. (2003). Higher education and development in Asia. Journal of Educational Planning and Administration, 17(2), 151-173. doi:10.1007/978-94-017-33687_56

Tongco, M. (2007). Purposive sampling as a tool for informant selection. Retrieved from http://journals.sfu.ca/era/index.php/era/article/viewFile/126/111

UN. (1996). Report on the Fourth World Conference on Women: Beijing, 4-15 September 1995. Retrieved from http://www.un.org/womenwatch/daw/beijing/pdf/Beijing full report E.pdf

UN. (2000). United Nations Millennium Declaration. Resolution adopted by the General Assembly. Retrieved from http://www.un.org/millennium/declaration/ares552e.htm

UN. (2001). Road map towards the implementation of the United Nations Millennium declaration: Report of the Secretary-General. Retrieved from http://unpan1.un.org/intradoc/groups/public/documents/UN/UNPAN004152.pdf

UN. (2015). Transforming our world: The 2030 agenda for sustainable development. Resolution adopted by the General Assembly on 25 September 2015. Retrieved from https://cil.nus.edu.sg/wp-content/uploads/2015/12/Ses6-1.A.RES_70.1Transforming-our-world-the-2030-Agenda-for-SustainableDevelopment-UNGAOR-70th-Sess-Goal-14-14.a..pdf

UN. (2017a). Sustainable Development Goals for Laos (SDG 4: quality education). Retrieved from http://www.la.one.un.org/sdgs/sdg-4-education

UN. (2017b). World population prospects: The 2017 revision, key findings and advance tables. . Retrieved from https://esa.un.org/unpd/wpp/Publications/Files/WPP2017_KeyFindings.pdf

UNCTAD. (2017). UN list of least developed countries. Retrieved from http://unctad.org/en/pages/aldc/Least Developed Countries/UN-list-of-LeastDeveloped-Countries.aspx

UNDP. (2008). Empowered and equal. gender equality strategy 2008-2011. Retrieved from

http://www.peacewomen.org/assets/file/PWandUN/UNImplementation/Program mesAndFunds/UNDP/gender-equality-strategy-2008-2011.pdf

UNDP. (2015). Lao PDR country analysis report: Analysis to inform the Lao People's Democratic Republic - United Nations Partnership Framework (2017-2021). . Retrieved from http://www.la.undp.org/content/lao_pdr/en/home/library/mdg/country-analysisreport.html.

UNDP. (2017a). Graduation from least developed country status, Lao PDR 2017. Retrieved from http://www.la.undp.org/content/lao_pdr/en/home/library/human_development/th e-5th-national-human-development-report.html 
UNDP. (2017b). Promote gender equality and empower women. Retrieved from http://www.la.undp.org/content/lao_pdr/en/home/post2015/mdgoverview/overview/mdg3.html

UNESCAP. (2014). Statistical yearbook for Asia and the Pacific. Retrieved from http://www.unescap.org/sites/default/files/ESCAP-SYB2014.pdf

UNESCO. (2013). Policy review of TVET in Lao PDR. Retrieved from http://unesdoc.unesco.org/images/0022/002211/221146E.pdf

UNESCO. (2015). Global monitoring report 2015: Education for All 2000-2015: Achievements and challenges. Retrieved from http://unesdoc.unesco.org/images/0023/002322/232205e.pdf

UNFPA. (2015). Population situation analysis: Lao PDR. Retrieved from http://lao.unfpa.org/sites/default/files/pub-pdf/PSA LAYOUT.pdf

UNICEF. (2010). An analysis of the situation of children in Viet Nam 2010. Retrieved from https://www.unicef.org/sitan/files/SitAn-Viet_Nam_2010_Eng.pdf

Verba, S., Schlozman, K. L., \& Burns, N. (2005). Family ties: Understanding the intergenerational transmission of political participation. In A. S. Zuckerman (Ed.), Social logic of politics (pp. 95-114). Philadelphia: Temple University Press.

Vilavong, B., \& Hess, S. (2016). What the AEC means for Laos. East Asia Forum. Retrieved from http://www.eastasiaforum.org/2016/01/01/what-the-aec-means$\underline{\text { for-laos/ }}$

Visvanathan, N., Duggan, L., Nisonoff, L., \& Wiegersma, N. (1997). The women, gender, and development reader. New Jersey: ZED Books.

Vogt, W. P. (2005). Dictionary of statistics \& methodology [electronic resource]: A nontechnical guide for the social sciences (3rd ed.). Los Angeles: Sage Publications.

Vongpraseuth, T., \& Choi, C. G. (2015). Globalization, foreign direct investment, and urban growth management: Policies and conflicts in Vientiane, Laos. Land Use Policy, 42, 790-799. doi:10.1016/j.landusepol.2014.10.003

WHO. (2014). Lao People's Democratic republic statistics. Retrieved from http://www.who.int/countries/lao/en/

World Bank. (2003). Gender equality and the Millennium Development Goals. Retrieved from

http://siteresources.worldbank.org/INTGENDER/Publications/20706126/gender $\underline{\text { mdg.pdf }}$

World Bank. (2012). World development indicators 2012. Retrieved from http://documents.worldbank.org/curated/en/553131468163740875/pdf/681720P UB0EPI004019020120Box367902B.pdf 
World Bank. (2016). The labour impact of Lao export growth. Retrieved from http://documents.worldbank.org/curated/en/551421468047786244/AUS9112MAIN-REPORT-REVISED.pdf

World Bank. (2017). Propostion of seats held by women in national paliament (\%). Retrieved from

https://data.worldbank.org/indicator/SG.GEN.PARL.ZS?locations=LA

World Population Review. (2017). Laos population 2017. Retrieved from http://worldpopulationreview.com/countries/laos-population/

Yadollahi, M., \& Paim, L. H. (2010). Measurement of family economic status. Journal of American Sciences, 6(11), 756-760. Retrieved from http://www.jofamericanscience.org/journals/amsci/am0611/109_3893am0611_756_760.pdf

Ziderman, A., \& Albrecht, D. (1995). Financing universities in developing countries. London: The Falmer Press. 


\section{Appendix 1: Human ethics approval}

TE WHARE WĀNANGA O TE ŪPOKO O TE IKA A MĀUI

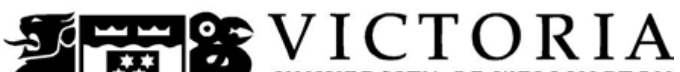

UNIVERSITY OF WELLINGTON

MEMORANDUM

Phone

Email

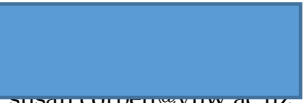

\begin{tabular}{l|l}
\hline TO & Kinnaphone Sounthongdeng \\
\hline COPY TO & Prof John Overton \\
\hline FROM & AProf Susan Corbett, Convener, Human Ethics Committee \\
\hline DATE & 2 May 2017 \\
\hline PAGES & 1 \\
\hline SUBJECT & $\begin{array}{l}\text { Ethics Approval: } 24455 \\
\text { Exploring the individual motivations and social norms regarding } \\
\text { women's access to tertiary education in Vientiane Capital, Lao } \\
\text { PDR }\end{array}$ \\
\hline
\end{tabular}

Thank you for your application for ethical approval, which has now been considered by the Standing Committee of the Human Ethics Committee.

Your application has been approved from the above date and this approval continues until 5 March 2018. If your data collection is not completed by this date you should apply to the Human Ethics Committee for an extension to this approval.

Best wishes with the research.

Kind regards

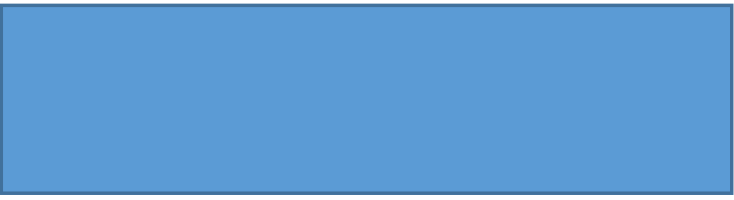

Susan Corbett

Convener, Victoria University Human Ethics Committee 
บิลขับขึภภาบอะบุมัถ

\begin{tabular}{|c|c|}
\hline เท็ต & ข่าบบ99 ภิบบะณงบ สูบยางสถดง \\
\hline สำเบิาสิ่งใช้ & ข่าบ สจ. จจบ โจเอ๊ตับ \\
\hline จาร & 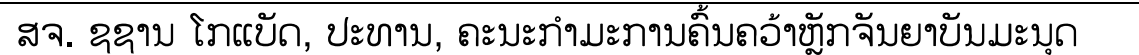 \\
\hline อับขิ & 2 ฝึกสะฆา 2017 \\
\hline ขังเจ้ย & 1 (ขก่ง) \\
\hline ชิอฉ้̆ & 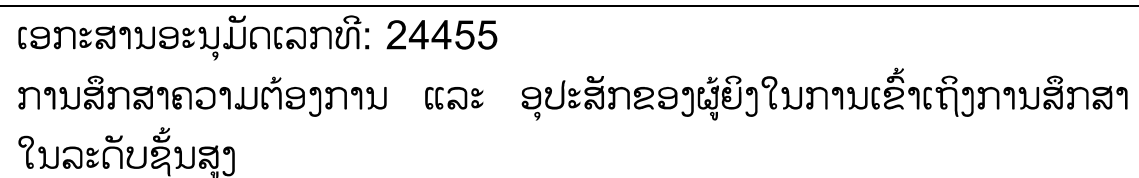 \\
\hline
\end{tabular}

ฉฉอบใจสำลับเอภะสาบอะบุมัลถ้ามจับยขบับมะบุด,

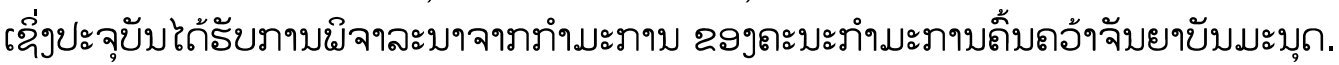

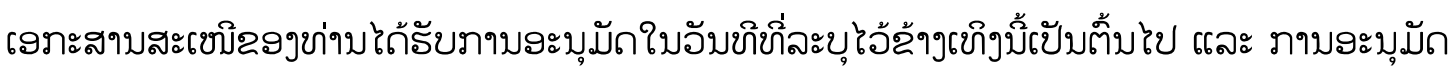

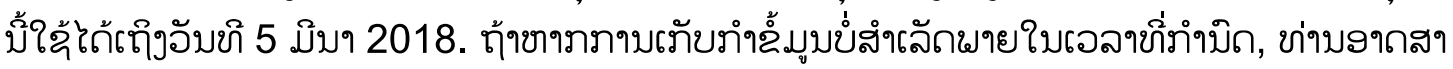

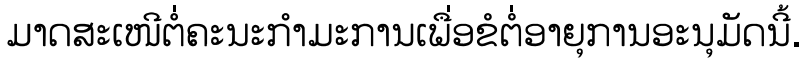

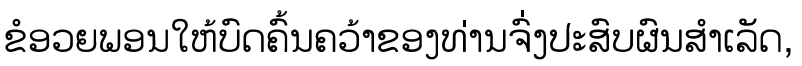

เฉับโดย: ข่าบ รูวาบ โภแบัถ

ถะบะทำมะภาบบถิ้มถอ้าขั้าจับยาบับมะบุถ 


\section{Appendix 2: Supervisor's support letter}

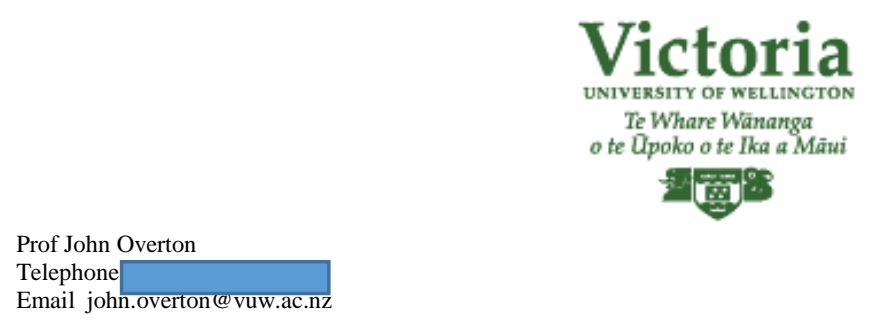

17 May 2017

To Whom It May Concern:

It is my pleasure write a letter in support of Kinnaphone Sounthongdeng's research for her Development Studies thesis on "Women and tertiary education: Exploring individual motivations and barriers regarding women's access to tertiary education". She is enrolled as a master's student in Development Studies at Victoria University of Wellington, Wellington, New Zealand and the research project is work towards her Master's thesis. Her research will be conducted from June to September 2017 in Vientiane Capital, Lao PDR. I am supervising her thesis research and I am the Director of the Postgraduate Programme in Development Studies.

The objective of this research is to explore and understand how individual motivations and social norms influence women's access to tertiary education in Vientiane. The work involves interviews with various officials, stakeholders and individuals in Lao PDR. This research will provide a better understanding of issues, challenges and opportunities that helps inform tertiary education policy and practice. Her research proposal has been approved by the Head of School and obtained ethics approval from the Human Ethics Committee of Victoria University of Wellington.

As Kinnaphone's supervisor, I fully support her research programme towards her Master's thesis. I would be grateful for any assistance you could offer her.

If you need any additional information from me please contact me at Victoria University of Wellington or calling me at - and my email address is john.overton@vuw.ac.nz. Or you can contact Kinnaphone Sounthongdeng by calling at +856 $202300 \quad 3673$ or +64 $220 \quad 099 \quad 0442$, and her email address is kinnaphone.ny04@gmail.com.

Yours sincerely,

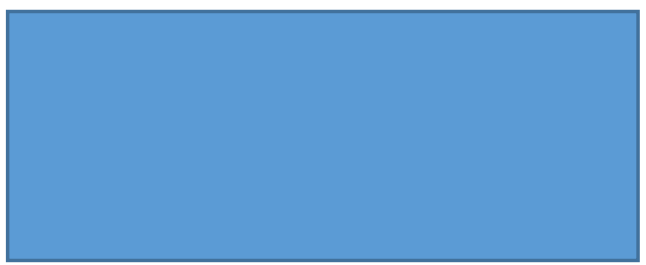

(Prof. John Overton

Director, Postgraduate Programme in Development Studies) 


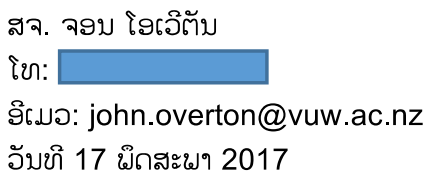

เท็ง: ฉัธรบขุภยางส่อบขึ่งรอฉ้งต

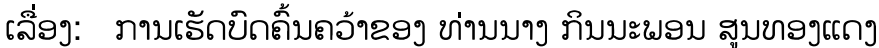

ฉ้าษะเจิ้า2รบเอาะสาบสะบับบิ้

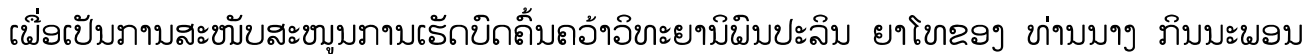

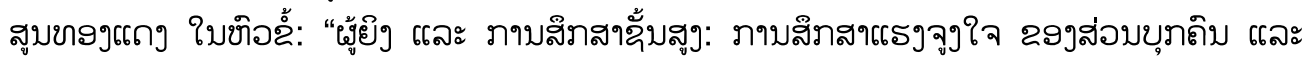

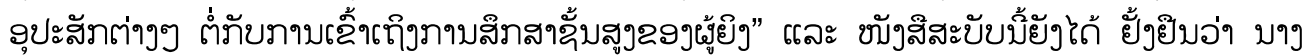

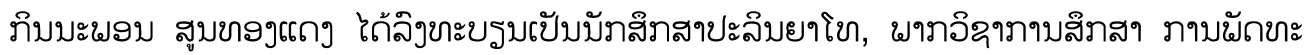

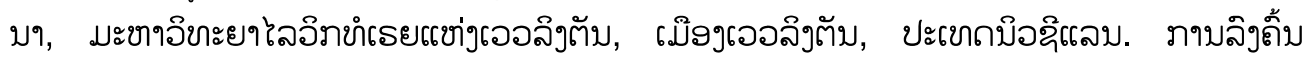

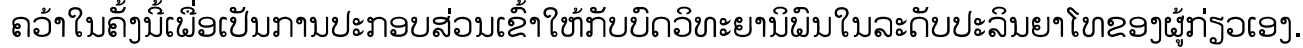

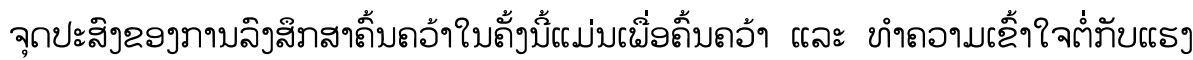

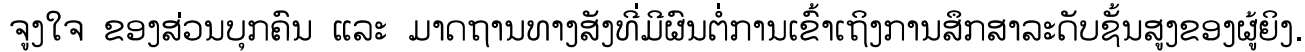

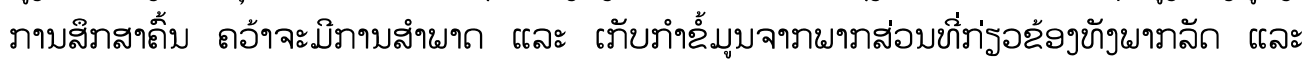

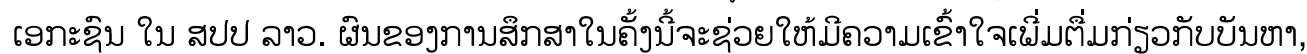

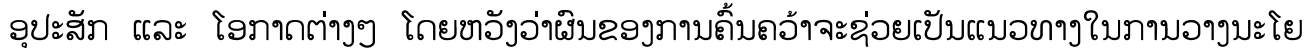

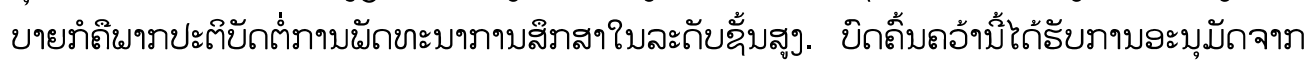

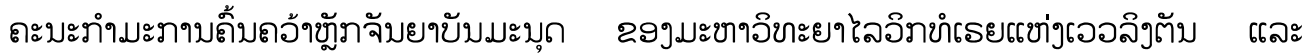

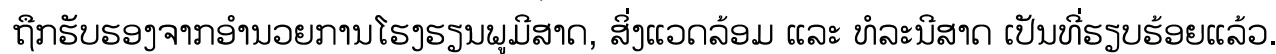

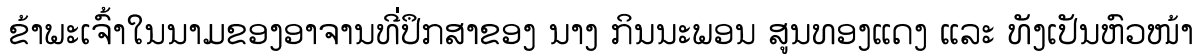

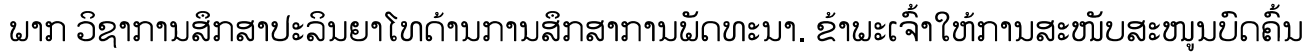

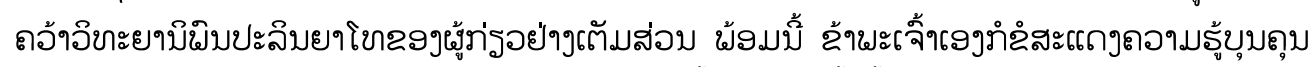
ย่างยิ่งมายัง ข่าบขิ่ใช้างบฉ่อยเขู๊อใบภาบเธักขิลถิ้มถอ้าใบถั้งบิ้ถ้อย.

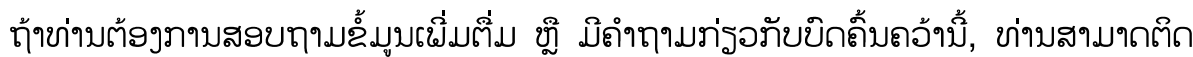

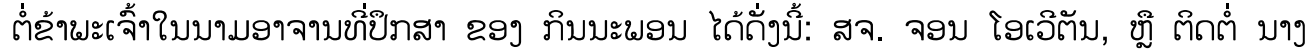
กิบบะฆ9บ โดยภิg: $0202300 \quad 3673$, kinnaphone.ny04@gmail.com; sounthkinn@myvwu.ac.nz.

รรมบาถ้อยถอาบบับถึเปับย่างตูง,

สจ. จงบ โอเอ๊ตับ

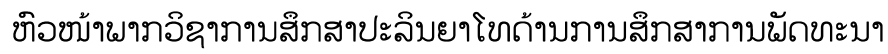

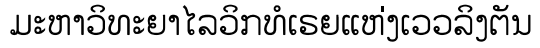




\title{
Appendix 3: Participant information sheet
}

\author{
TE Whare Wãnanga o te óporo o te IKa a māui \\ "Exploring individual motivations and social norms
regarding women's access to tertiary education" \\ INFORMATION SHEET FOR PARTICIPANTS \\ (FOR WOMEN AND PARENTS)
}

My name is Kinnaphone Sounthongdeng and I am a Masters student in Development Studies at Victoria University of Wellington. This research project is work towards my thesis.

Thank you for your interest in this project. Please read this information before deciding whether or not to take part. If you decide to participate, thank you. If you decide not to take part, thank you for considering my request.

This project aims to explore how individual motivations, parental involvement and social norms influence women's decisions to enrol or not in tertiary education. As well, the project will:

- Investigate how women's individual motivations influence whether they continue to study or not.

- Investigate how family characteristics (family size, and occupations) impact on women's education;

- Explore how social norms impact on women's decision making.

This research has been approved by the Victoria University of Wellington Human Ethics Committee 24455.

If you agree to take part, I will interview you in a place of your choosing. I will ask you questions about women and tertiary education. The interview will take around 30 to 60 minutes. I will record the interview and write it up later. You can stop the interview at any time, without giving a reason. You can withdraw from the study by contacting me at any point before 31 August 2017. If you withdraw, the information you provided will be destroyed or returned to you.

This research is confidential. I will not name you in any reports, and I will not include any information that would identify you. Only my supervisors and I will read the notes or transcript of the interview. The interview transcripts, summaries and any recordings will be kept securely and destroyed 3 years after the research ends. 
The information from my research will be used in my Masters Thesis. You will not be identified in my report. I may also use the results of my research for conference presentations, and academic reports. I will take care not to identify you in any presentation or report.

You do not have to accept this invitation if you don't want to. If you do decide to participate, you have the right to:

- choose not to answer any question;

- $\quad$ ask for the recorder to be turned off at any time during the interview;

- $\quad$ withdraw from the study at any point before 31 August 2017;

- $\quad$ ask any questions about the study at any time;

- $\quad$ receive a copy of your interview recording (if it is recorded);

- $\quad$ read over and comment on a written summary of your interview;

- $\quad$ agree on another name for me to use rather than your real name;

- be able to read any reports of this research by emailing the researcher to request a copy.

If you have any questions, either now or in the future, please feel free to contact either:

\section{Student:}

Name: Kinnaphone Sounthongdeng

University email address:

sounthkinn@myvuw.ac.nz

\section{Human Ethics Committee information}

If you have any concerns about the ethical conduct of the research you may contact the Victoria University HEC Convener: Associate Professor Susan Corbett. Email susan.corbett@vuw.ac.nz or telephone

\section{Supervisor:}

Name: Prof. John Overton

Role: Director of Postgraduate Program

in Development Studies

School: School of Geography,

Environment and Earth Sciences

Phone: john.overton@vuw.ac.nz 


\section{"Exploring individual motivations and social norms regarding women's access to tertiary education" \\ INFORMATION SHEET FOR PARTICIPANTS (FOR OFFICERS)}

My name is Kinnaphone Sounthongdeng and I am a Masters student in Development Studies at Victoria University of Wellington. This research project is work towards my thesis.

Thank you for your interest in this project. Please read this information before deciding whether or not to take part. If you decide to participate, thank you. If you decide not to take part, thank you for considering my request.

This project aims to explore how individual motivations, parental involvement and social norms influence women's decisions to enrol or not in tertiary education. As well, the project will:

Investigate how women's individual motivations influence whether they continue to study or not.

Investigate how family characteristics (family size and occupations) impact on women's education;

Explore how social norms impact on women's decision making.

This research has been approved by the Victoria University of Wellington Human Ethics Committee 24455.

If you agree to take part, I will interview you in your office. I will ask you questions about women and tertiary education. The interview will take around 30 to 60 minutes. I will record the interview and write it up later. You can stop the interview at any time, without giving a reason. You can withdraw from the study by contacting me at any point before 31 August 2017. If you withdraw, the information you provided will be destroyed or returned to you.

This research is confidential. I will not name you in any reports, only your role and organization will be referred in this research with your consent. However, you should be aware that your position might be recognised by others. Only my supervisors and I will read the notes or transcript of the interview. The interview transcripts, summaries and any recordings will be kept securely and destroyed 3 years after the research ends.

The information from my research will be used in my Masters Thesis. You will not be identified in my report, only your role and your organization will be referred. I may also 
use the results of my research for conference presentations, and academic reports. I will take care not to identify you in any presentation or report.

You do not have to accept this invitation if you don't want to. If you do decide to participate, you have the right to:

- choose not to answer any question;

- $\quad$ ask for the recorder to be turned off at any time during the interview;

- $\quad$ withdraw from the study at any point before 31 August 2017;

- $\quad$ ask any questions about the study at any time;

- $\quad$ receive a copy of your interview recording (if it is recorded);

- $\quad$ read over and comment on a written summary of your interview;

- $\quad$ agree on another name for me to use rather than your real name;

- be able to read any reports of this research by emailing the researcher to request a copy.

If you have any questions, either now or in the future, please feel free to contact either:

\section{Student:}

Name: Kinnaphone Sounthongdeng

University email address:

sounthkinn@myvuw.ac.nz

\section{Supervisor:}

Name: Prof. John Overton

Role: Director of Postgraduate Program

in Development Studies

School: School of Geography,

Environment and Earth Sciences

Phone:

john.overton@vuw.ac.nz

\section{Human Ethics Committee information}

If you have any concerns about the ethical conduct of the research you may contact the Victoria University HEC Convener: Associate Professor Susan Corbett. Email susan.corbett@vuw.ac.nz or telephone 


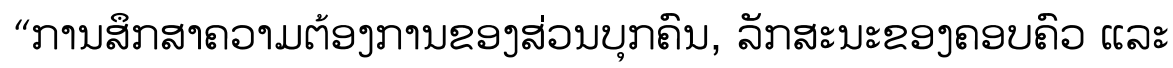
บาถฤาบขางสังถิม

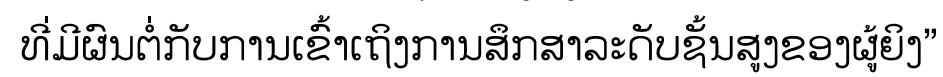

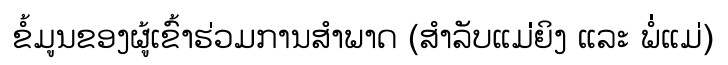

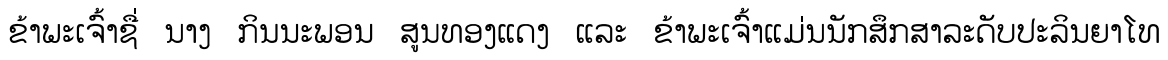

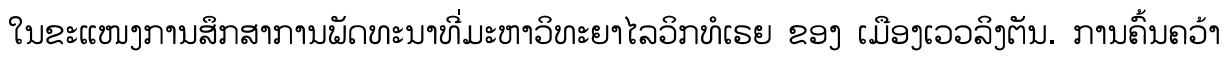

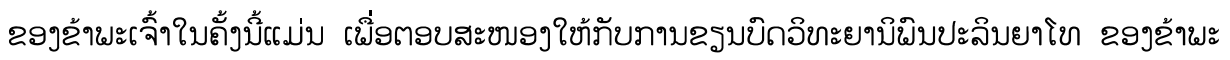
เจ้้าเงต.

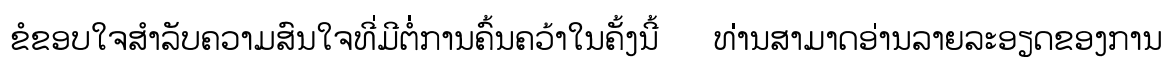

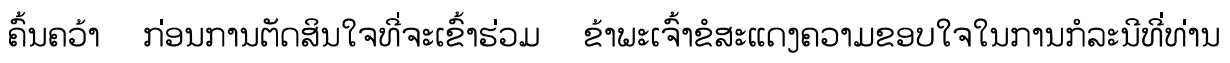

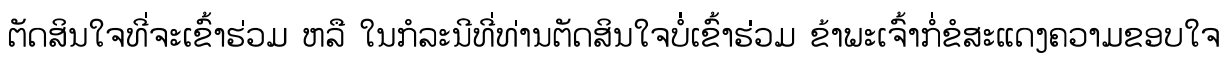
ใบภาบฆิจาละบารองข่าบ.

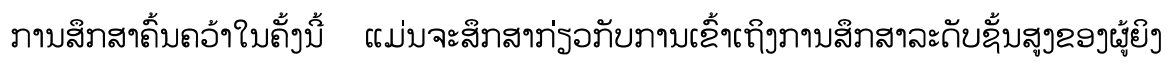

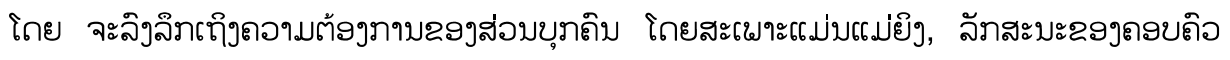

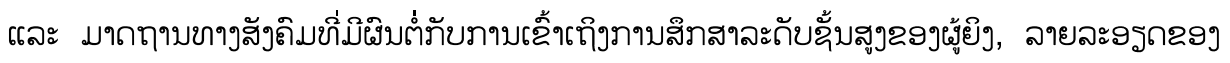
ภาบสึภสามิถั่วลุ่บบิ้:

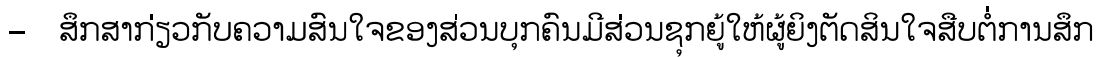
สงละถับฉั้บสูงสบอใด;

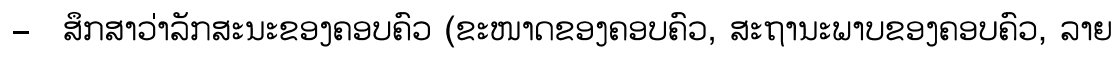

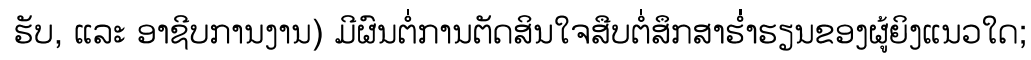

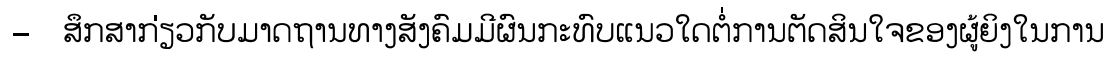
สิบติ่ภาบสึภสา.

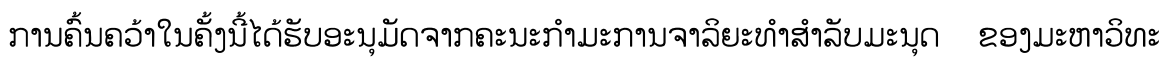

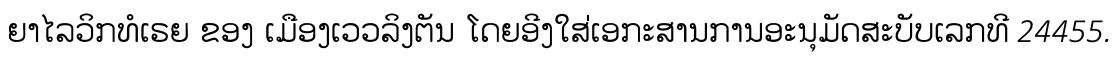

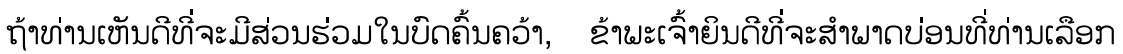

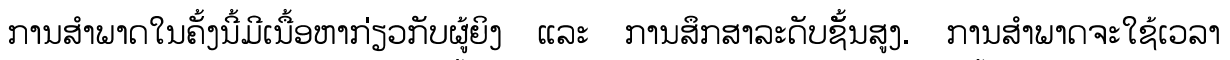

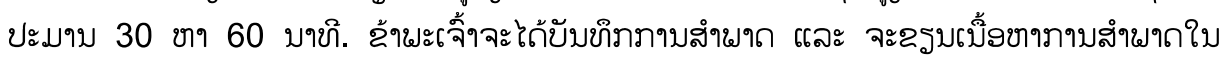

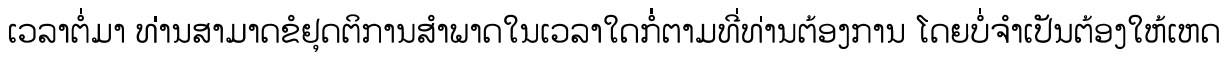

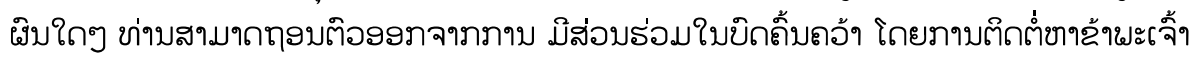




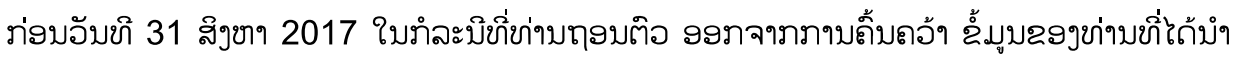

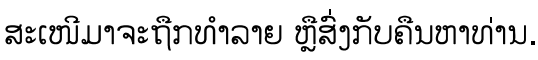

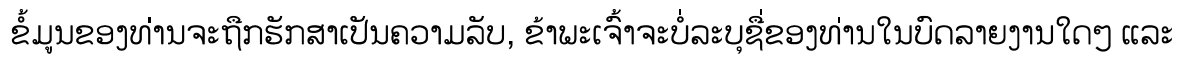

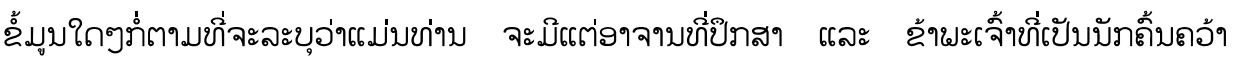

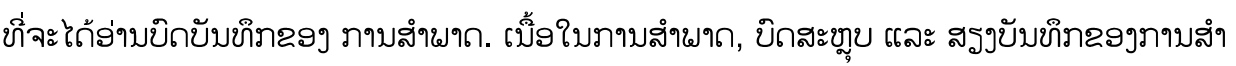

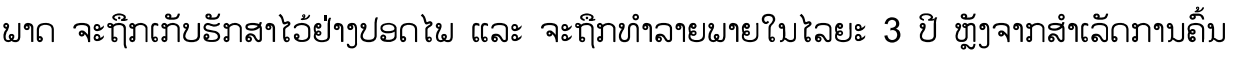
ถอ้า.

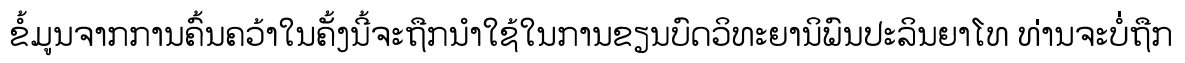

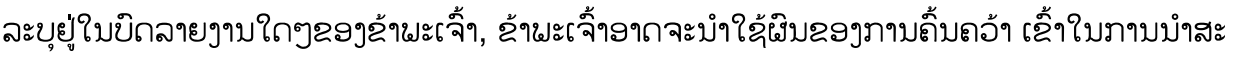

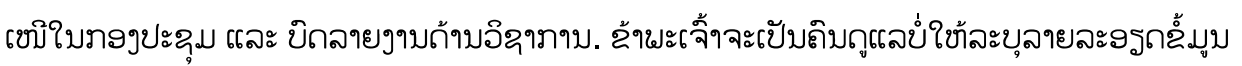
29งโตข่าบใบบิถสะเข็ิ ขู์ บิถลายงาบใถๆ.

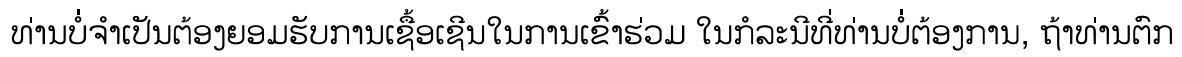

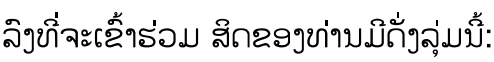

- ข่าบสามากเล็องขั่จะบ่่ตอบถำฤาม;

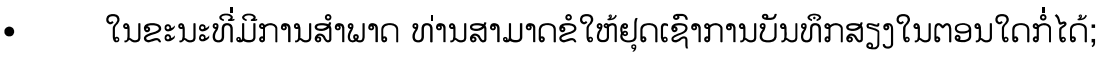

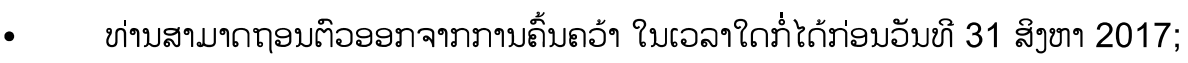

- ข่าบสามาถฤามถำฤามร่รอภับภาบถิ้มถอ้าใบตอบใถภ่่ใถ้;

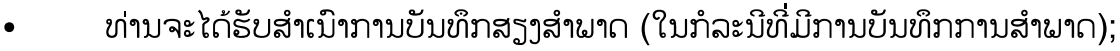

- ข่าบสามาถอ่าบ และ ใช้ถำเขับต่ํับภาบสะขูบเบิ้อใบภาบสำะดถ;

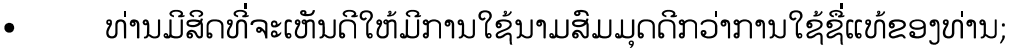

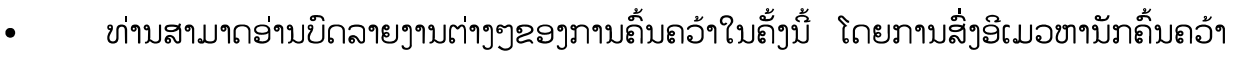
เผื่อฉสำ เบิา

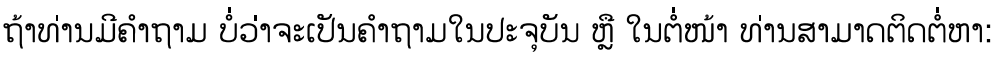

มัภธรบ:

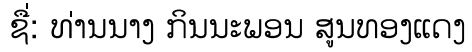

ที่ยู่อิเมอนองมะขางอิยะยาไล

sounthkinn@myvuw.ac.nz
อาจาบขี่ปัภสา:

ฉั่: สาถสะถาจาบ จอบ โอเอิตับ

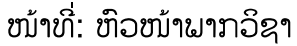

กาบสึกราภาบบัักขะบา

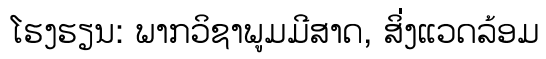

และ ขำบบสาถ

เบิโขละสับ:

john.overton@vuw.ac.nz

ฉั้มูบฉองถะบะรำมะภางบจาล์ยะขำสำลับบะบุถ

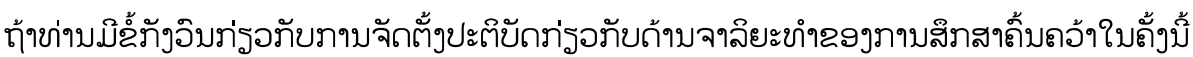

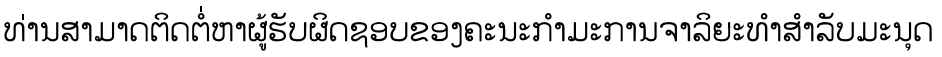
2องมะขาออ์ขะยาไลอ็กขำรย (Victoria University HEC Convener): ผู้น้ว่อยสาถสะถาจาบ ข่าบ 
วูุ१บ โถเบัถ (Associate Professor Susan Corbett). ขี่่ยู่อิธมอ: susan.corbett@vuw.ac.nz, เบิโขละสับ: 
“ราบสึภสาถอาบต้องภาบะองส่อบบุภถิบ, ลักสะบะฉองถอบถิอ และ บขถฤๆบขางสังถ์ฝ

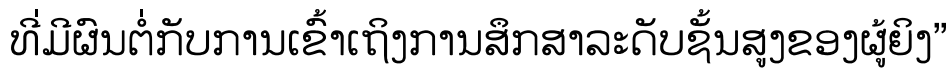

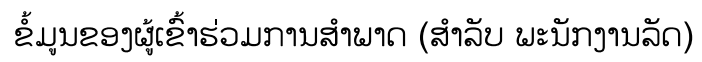

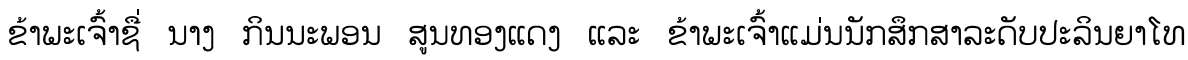

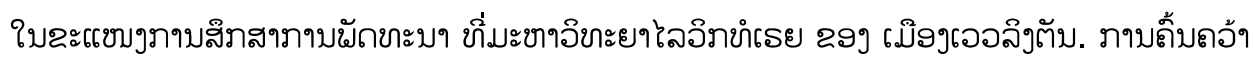

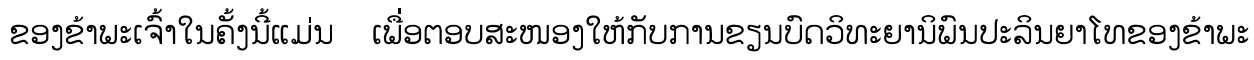
เจิ้าเร9.

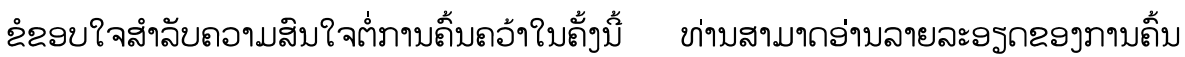

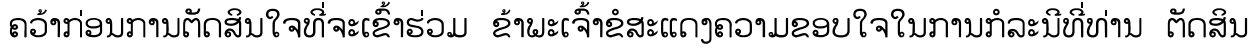

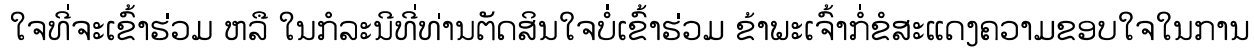
ผิจาละบานรยข่าบ.

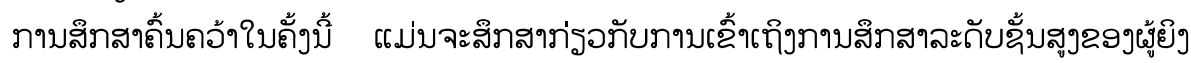

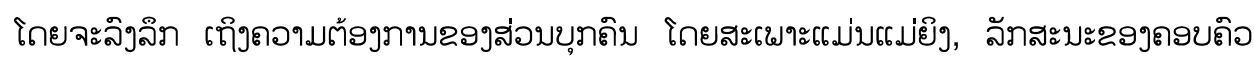

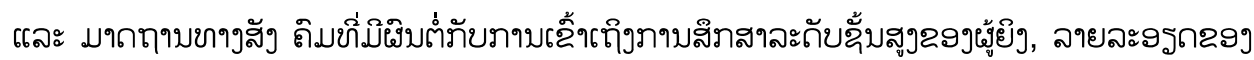
ภขบลึกสามักั่วลุ่บบิ้:

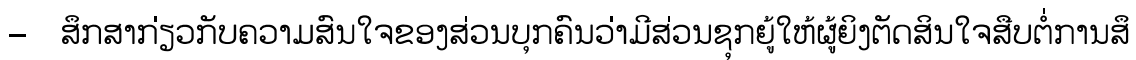
กสาละกับลั้บสูรเบอใด

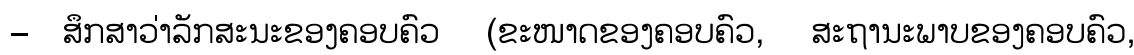

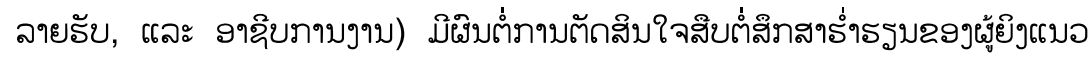
ใด;

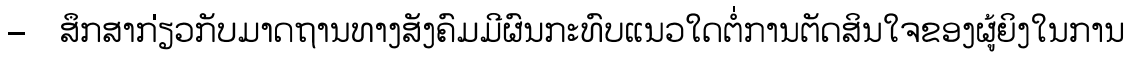
สึบต่ำบบสึกสา.

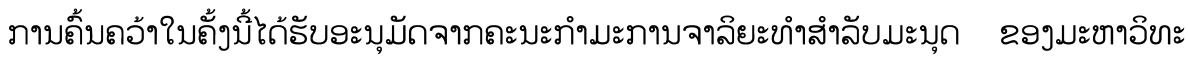

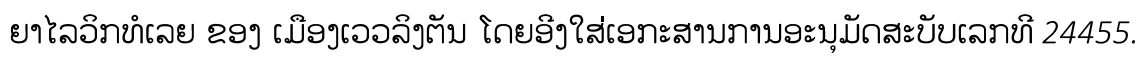

ท้าชท่าบเทับถิชิ่จะมิร่อบธ่อมใบขิกถิ้บถอ้า,

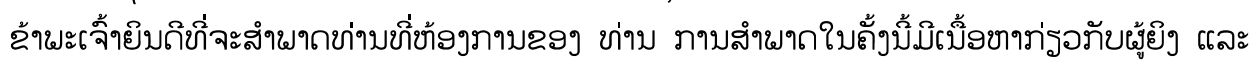

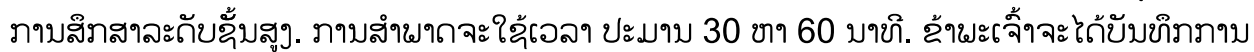

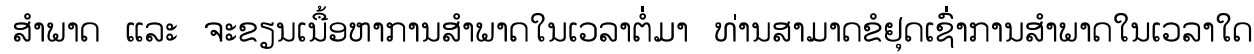

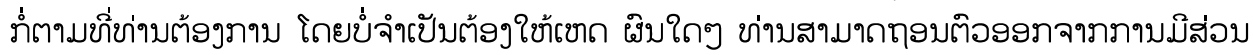

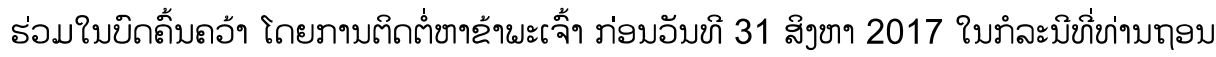




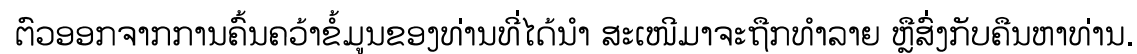

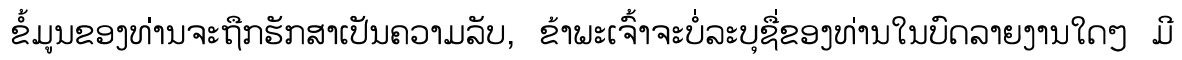

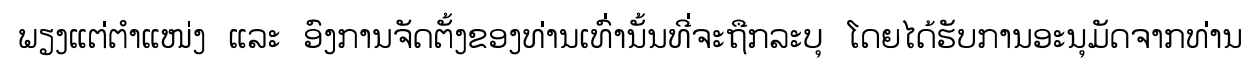

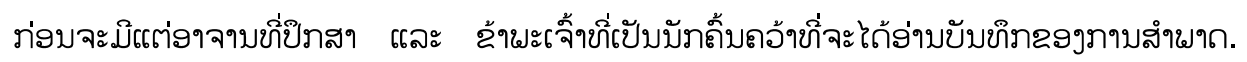

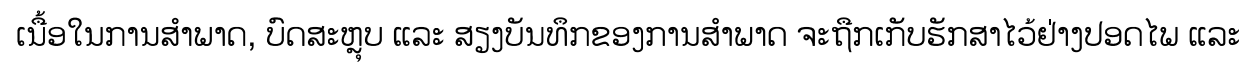
จะทิภขำลายะายใบไลยะ 3 ปี ฆูัปจารสำ เลักภาบถิ้บถอ้า.

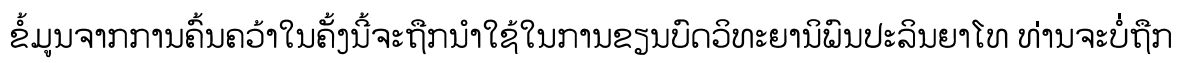

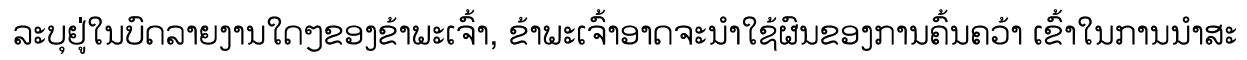

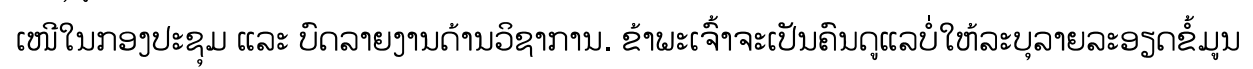
29ตโตข่าบใบบิถสะเขิบ ขู๊ บิถลายงาบใดๆ.

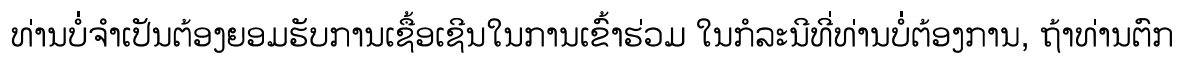

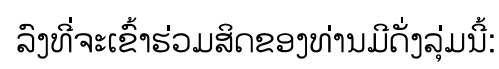

- ข่าบสามาถเล็องขิ่จะบ่่ตอบถำฤาม;

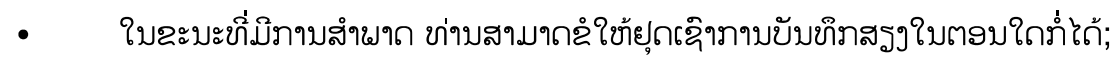

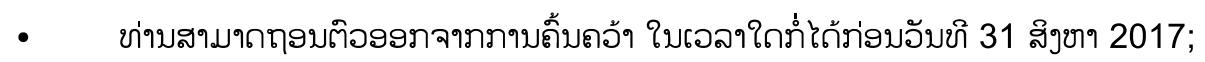

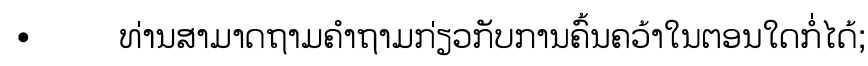

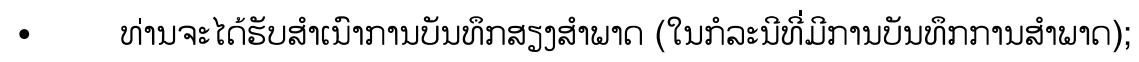

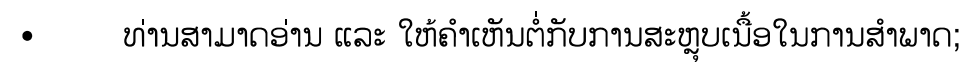

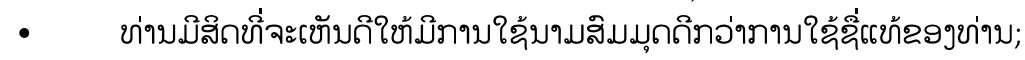

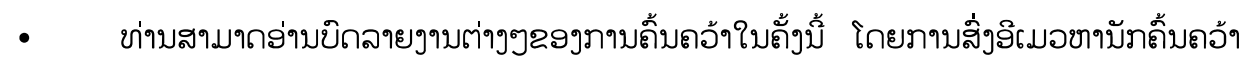
เผื่อฉสำ เบิา

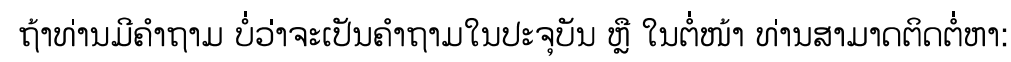

บัภธรม:

ฉุ่: ข่าบบาง ภิบบะฆอบ สูบยาองแถง

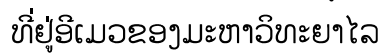

sounthkinn@myvuw.ac.nz
งาจาบขั่ปิภสา:

ฉั่: สาถสะถาจาบ จจบ โจเอิตับ

ข้งขิ่: จำบอยภาบฉะเซขบง

ภาบสึกสาภาบผัถขะ บา

โธงรรม: ฝูมปิสาก, สิ่งแอถล้อม และ

ขำะบิสาถ

เขิโขละสับ:

john.overton@vuw.ac.nz

ฉั้มูบะองถะบะรำมะภาบจาล์ยะทำสำลับมะบุถ

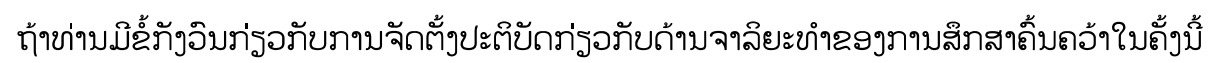

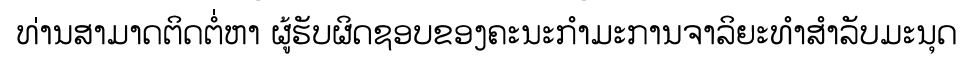

299มะยาอําะยงใลอกขำลย (Victoria University HEC Convener): เู้้น่อยสาถสะถาจาบ ข่าบ 
วูุาบ โถเบัด (Associate Professor Susan Corbett). ขี่ยู่อิโมอ: susan.corbett@vuw.ac.nz, เบิโขละสับ: 


\title{
Appendix 4: Research consent form
}

\author{
TE WHARE WĀNANGA O TE ŨPOKO O TE IKA A MĀUI

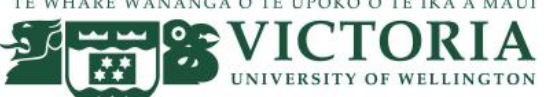 \\ "Exploring individual motivations, and social norms regarding \\ women's access to tertiary education" \\ CONSENT TO INTERVIEW (FOR OFFICERS)
}

This consent form will be held for 3 years.

Researcher: Ms. Kinnaphone Sounthongdeng, School of Geography, Environment and Earth Sciences, Victoria University of Wellington

\begin{abstract}
I have read the Information Sheet and the project has been explained to me. My questions have been answered to my satisfaction. I understand that I can ask further questions at any time.

I agree to take part in an audio recorded interview.

I understand that I may withdraw from this study at any point before 31 August 2017, and any information that I have provided will be returned to me or destroyed.

I understand that the information I have provided will be destroyed 3 years after the research is finished.

I understand that, any information I provide will be kept confidential to the researcher and the supervisor. I understand that the results will be used for a Master Thesis and a summary of the results may be used in academic reports and/or presented at conferences.
\end{abstract}

\section{Please tick as appropriate}

- I consent to information or opinions which I have given being $\quad$ Yes $\square$ No attributed to my organisation in any reports on this research:

- I would like a summary of my interview:

Yes $\square \quad$ No

- I would like to receive a summary of the final report and have added my email address below.

Yes $\square \quad$ No

Name:

Phone:

Organization:

E-mail:

Signature:

Date: 


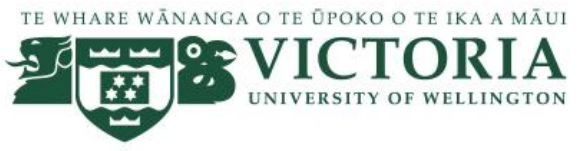

\section{"Exploring individual motivations, and social norms regarding women's access to tertiary education" \\ CONSENT TO INTERVIEW (FOR WOMEN AND PARENTS)}

This consent form will be held for 3 years.

Researcher: Ms. Kinnaphone Sounthongdeng, School of Geography, Environment and Earth Sciences, Victoria University of Wellington

I have read the Information Sheet and the project has been explained to me. My questions have been answered to my satisfaction. I understand that I can ask further questions at any time.

I agree to take part in an audio recorded interview.

I understand that I may withdraw from this study at any point before 31 August 2017 , and any information that I have provided will be returned to me or destroyed.

I understand that the information I have provided will be destroyed 3 years after the research is finished.

I understand that, any information I provide will be kept confidential to the researcher and the supervisor. I understand that the results will be used for a Master thesis and a summary of the results may be used in academic reports and/or presented at conferences.

My name will not be used in reports, nor will any information that would identify me.

\section{Please tick as appropriate}

- I would like a summary of my interview:

Yes $\square \quad$ No

- $\quad$ I would like to receive a summary of the final report and have Yes $\square$ No added my email address below.

Name:

Organization:

Signature:
Phone:

E-mail:.

Date: 


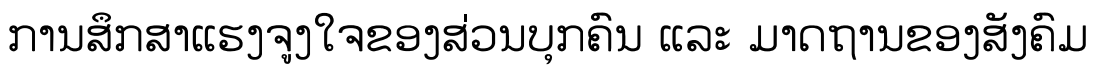

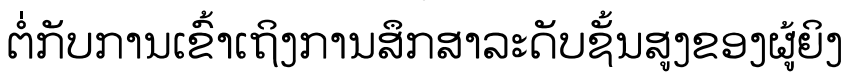

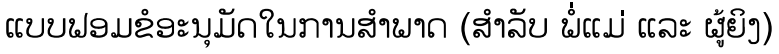 \\ แบบฝอบภาบอะมุมัถภาบสำฝาถจะป๋อายุ 3 ปิ}

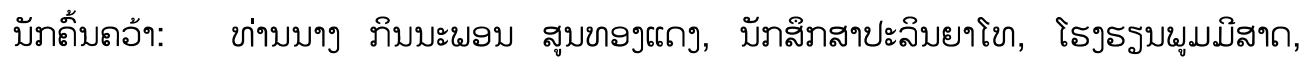

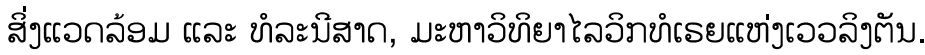

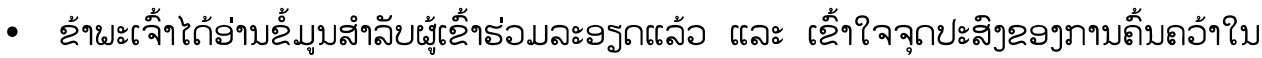

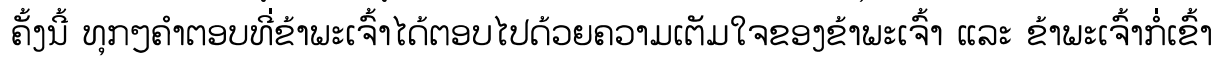

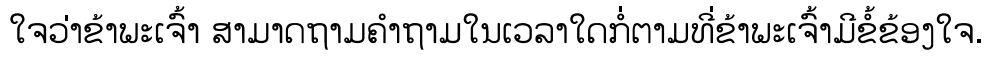

- ฉ้าษะเจิ้าจะบุยาดใข้มิภาบบับขึภสรงใบเอลาสำษๆถ.

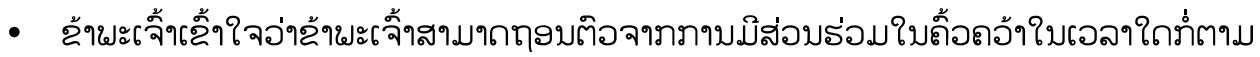

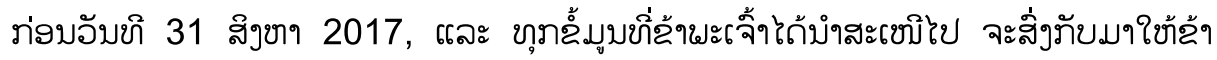
๒ะเจิ้า ฑู๊ ท๊ภทำลาย.

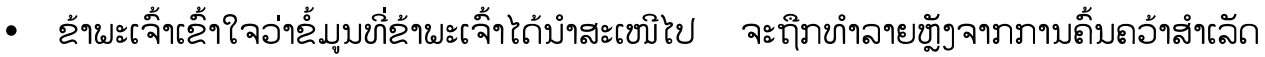
ขายใบเอลา 3 ปี.

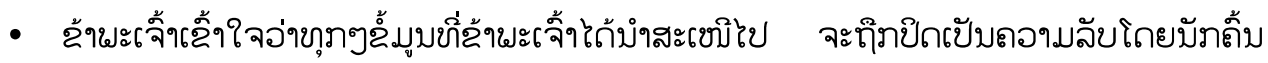

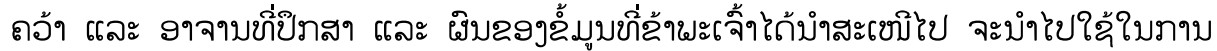

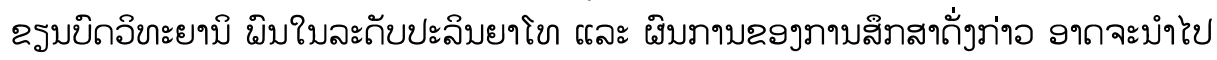

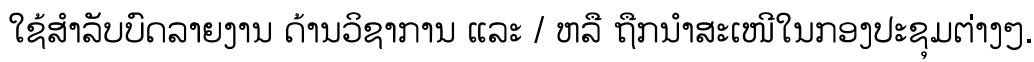

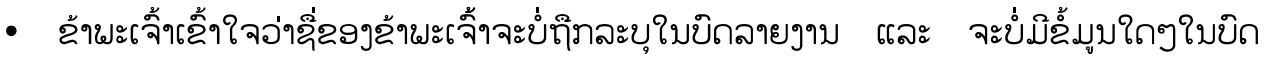
ลายงาบขิ่ จะสามๆถละบุไถ้อ่าแม่บมาจารฉ้าษะเจิ้า.

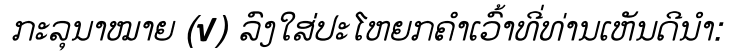

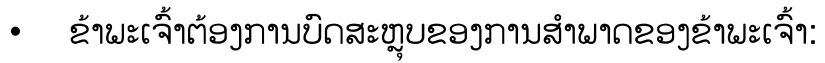

๘ม่บ

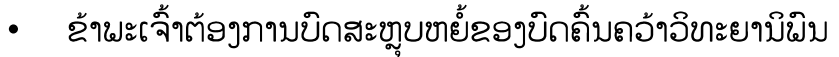

๘ม่บ $\square$ บे $\square$

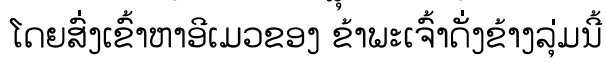

ฉิ่:

เขิโขละสับ:

อิรภาบจักตั้ง: อิธนอ:

ลายเฉับ:

อับขึ: 


\section{ภาบสึภสาแธงจูงใจะองส่อบบุภถิบ และ บาถฤาบะองสังถิม

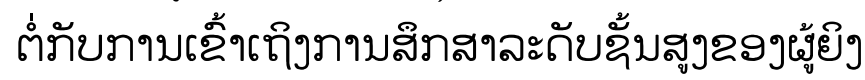 \\ แบบฝ9มฉำบุมักใบภาบสำยาด (สำลับ ฆะบัภงาบลัถ) \\ แบบฝอบภาบจะบุมัถภาบสำแาถจะป์อายุ 3 ปิ}

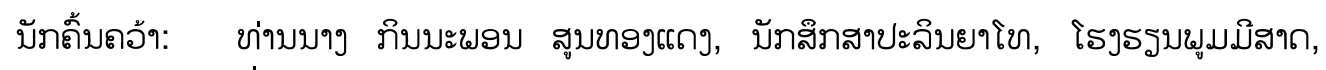

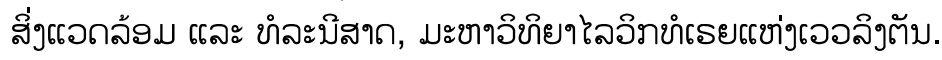

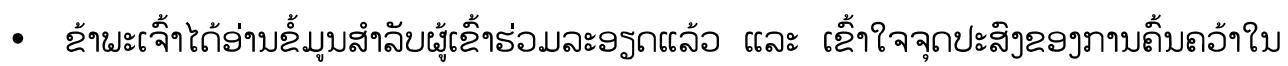

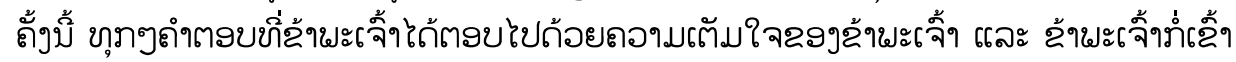

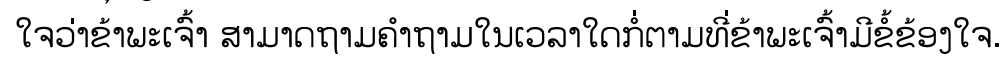

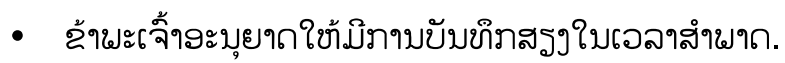

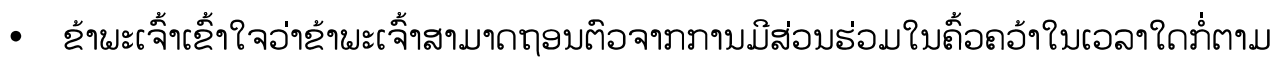

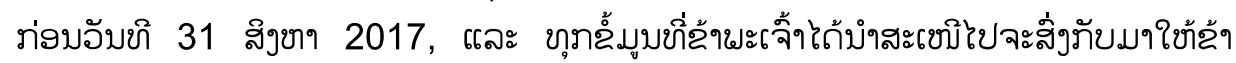
ยะเจ้้า ขู๊ ฤิภขำลาย.

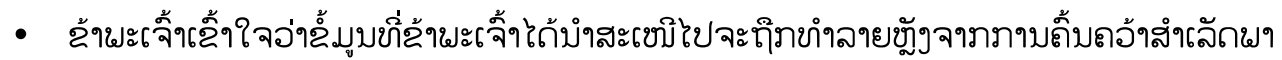
ยใบเอลา 3 ปิ.

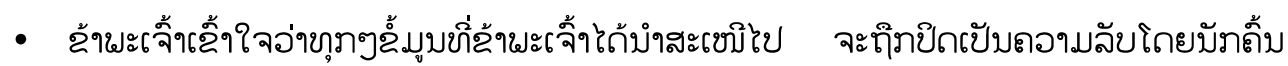

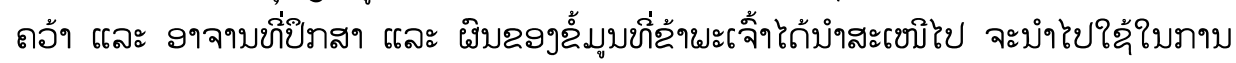

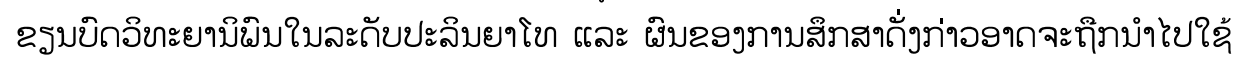

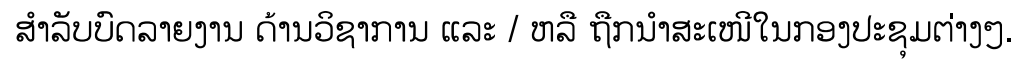

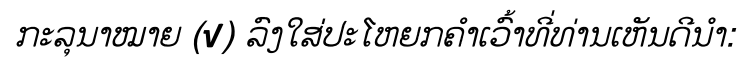

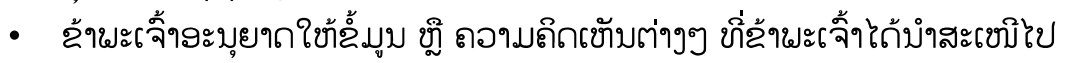

๘ม่บ口 บ்่

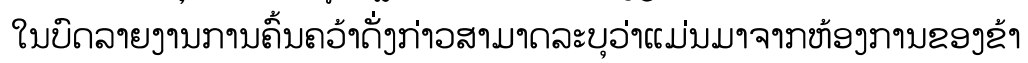
อะเจิ้า:

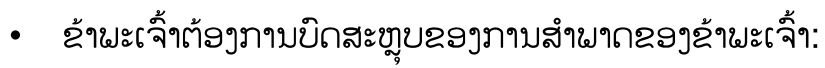

๓ม่ม口 บें

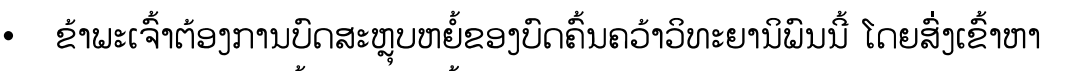
9ิเมอ ฉองฉ้านะเจิ้ายู่อ้างจุ่มบิ้

ฉे:

จิรภาบจัดตั้ง:

ลายเฉับ:
เบิโขละสับ:

อิเมอ:

อับขิ: 


\section{Appendix 5: Interview questions}

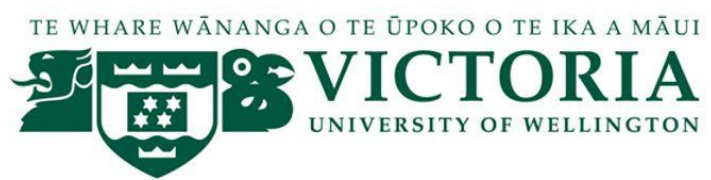

INTERVIEW QUESTIONS

“Exploring individual motivations and social norms regarding women's access to tertiary education"

Q1: Women students who are currently student in tertiary education

1. Personal information (Age, name of school, education level, etc)

The importance of education for women

2. Do you think that education is important for you? Why or why not?

3. Do you think that higher education/bachelor degree is important for you? Why or why not?

4. What do you expect from study at higher education or bachelor degree? (Career, salary, quality of life and family)

5. Why did you decide to enroll at this university or college? What is the most interesting in this school?

Family characteristics

6. Do you think that your parent's occupation/family size/income/parents' status has influenced on your education?

7. Have your parents involved in your selection of a school or a course?

8. Have your parents assisted in or supported your study so far? Why or why not? How do they support?

9. Who respond for the payment/enrolment of your education fee? Why?

Women behavior

10. What do you like most?

11. What do you do in your free time?

12. What do you expect to do in your future?

13. What do you think about your behaviour? Preference or diligence in education or not? Why?

14. Do you think that you can make a decision by yourself or do what you want? Why or why not?

15. What do you think about your quality and efficiency of your study? 
16. Do you have enough time to study? How do you manage your household chores with other family members?

\section{Social norms and beliefs}

17. What do you think about your dressing, your speaking, etc. affect your study?

18. Do you think that social norms affect the decision making of your education? Why or why not? (Some social beliefs: women have to be a labor of a family, women have to do household chores)

19. Do you think that social beliefs in gender imbalance affect women's decision making on tertiary education? Why or why not? (Some social beliefs; woman gains a job harder than man, woman gets less salary than man, woman is in a lower position than man, working quality of woman is less than man, etc.).

20. With the same supports between man and woman, do you think who is going to be more successful in the study? Why or why not?

21. How do you feel when girls have to spend a lot of time on their household chores while their peer boys playing sports/with friends or do what they want?

22. Do you think that social norms affect women's education in your community? Why or why not?

\section{Gender imbalance in higher education}

23. Have you ever faced/heard gender issues in your class or school? Please give an example

24. Do you think that woman and man have equal access to tertiary education or bachelor degree after graduated from secondary school? In community? Why or why not?

25. What do you see as the main obstacles for women to access to tertiary education?

+ Family characteristics (income, family size, parent's occupations, etc.)

+ Woman's motivations (individual behaviour, time management

between learning and household chores, future career, etc.)

+ Schooling system (fees, courses, curricula, teacher quality, school facilities, location, etc.)

26. What do you think the main factor helps you to continue your study at tertiary education or bachelor degree? Why or why not?

\section{Encouraging women on their study}

27. Who are the most important sector to help women to improve their accessibility of tertiary education? Why or why not? And how do they do? 
28. What can your community/government do in order to encourage women on their accessibility of tertiary education?

29. Other recommendations or questions

\section{Q2: Women students who are not currently student in any tertiary education}

1. Personal information (Age, etc)

The importance of education for women

2. Do you think that education is important for you? Why or why not?

3. Do you think that higher education/bachelor degree is important for you? Why or why not?

4. What is your education level?

Family characteristics

5. Do you think that your parent's occupation/family size/income/parents' status has influenced on your education?

6. Have your parents assisted in or supported your study so far? Why or why not? How do they support?

7. Have your parents involved in your career's choice?

Women behavior

8. What do you like most?

9. What do you do in your free time?

10. What do you expect to do in your future?

11. What do you think about your behaviour? Preference or diligence in education or not? Why?

12. What do you think about your quality and efficiency of your study?

13. Do you have enough time to study? How do you manage your household chores with other family members?

14. Do you think that you can make a decision by yourself or do what you want? Why or why not?

\section{Current activities}

15. What is your occupation? And why did you decide to do this?

16. Who support you to do this occupation? Why?

17. What is it difficult or easy to do this activity/business/occupation?

18. Do you want to change to do another activity/business/occupation?

Social norms and beliefs

19. What do you think about your dressing, your speaking, etc. affect your study? 
20. Do you think that social norms affect the decision making of your education? Why or why not? (Some social beliefs: women have to be a labor of a family, women have to do household chores)

21. Do you think that social beliefs in gender imbalance affect women's decision making on tertiary education? Why or why not? (Some social beliefs; woman gains a job harder than man, woman gets less salary than man, woman is in a lower position than man, working quality of woman is less than man, etc.).

22. With the same supports between man and woman, do you think who is going to be more successful in the study? Why or why not?

23. How do you feel when girls have to spend a lot of time on their household chores while their peer boys playing sports/with friends or do what they want?

24. Do you think that social norms affect women's education in your community? Why or why not?

\section{Gender imbalance in higher education}

25. Have you ever faced/heard gender issues in your class or school? If yes, ple 
3) Does your daughter study at any tertiary education institution? Why or why not?

4) Why does your daughter enroll at this university? What is the most interesting for her?

Family characteristics

5) Do you think that your occupation/family size/income/parents' status has influenced on your children's education?

6) Have you involved in children's selection of a school or a course?

7) Have you assisted in or supported your children study so far? Why or why not? How do you support them?

8) Who respond for the payment/enrolment of your daughter's education fee? You or herself?

9) How do you feel with your daughter's education so far?

Women behaviour

10) What is your daughter's behaviour?

11) What does she do in her free time?

12) How do you manage your household chores with other members of your family?

13) Have you consulted with your children on how to manage their work?

14) Does your daughter spend a lot of time on study? Why or why not?

Social beliefs

15) Do you think that social norms affect the decision making regarding your children's education? Why or why not? (Some social beliefs: women have to be a labor of a family, women have to do household chores)

16) Do you think that social beliefs in gender imbalance affect women's decision making on tertiary education? Why or why not? (Some social beliefs; woman gains a job harder than man, woman gets less salary than man, woman is in a lower position than man, working quality of woman is less than man, etc.).

17) With the same supports between man and woman, do you think, who is going to be more successful in the study? Why or why not?

18) How do you feel when girls have to spend a lot of time on their household chores while their peer man playing sports/with friends or do what they want? 
19) Do you think that man has more chance on education than woman in your community? Why or why not?

20) Do you think that social norms affect women's education in your community?

\section{Daughter and education}

21) What do you think are the main strengths of yourself in helping your daughter to access university or college? What do you think are the main obstacles with your family that might prevent your daughter accessing tertiary education?

Encouraging women on their study

22) What can you do to help your daughter's study?

23) Who are the most important sector to help women to improve their accessibility of tertiary education? Why or why not? And how do they do?

24) What can your community/government do in order to encourage women on their accessibility of tertiary education?

25) Any recommendation or questions

\section{Q4: Parents of women who have not enrolled in any tertiary educational institution:}

1) Personal information (family size, occupations, economic status, etc.) Daughter and Education

2) Do you think that education/higher education is important for your children? Why or why not?

3) Does your daughter study at any tertiary education institution? Why or why not?

4) What is your daughter's education level?

Family characteristics

5) Do you think that your occupation/family size/income/parents' status has influenced on your children's education?

6) Have you assisted in or supported your children study so far? Why or why not? How do you support them?

7) How do you feel with your daughter's education so far?

Women behaviour

8) What is your daughter's behaviour?

9) What does she do in her free time? 
10) How do you manage your household chores with other members of your family? Have you consulted with them? Why or why not?

11) Does your daughter spend a lot of time on study? Why or why not?

\section{Current activities}

12) What is your daughter's occupation/business/activity? And why did she decide to do this?

13) Who support her to do this occupation/business/activity? Why?

Social norms and beliefs

14) Do you think that social norms affect the decision making regarding your children's education? Why or why not? (Some social beliefs: women have to be a labor of a family, women have to do household chores)

15) Do you think that social beliefs in gender imbalance affect women's decision making on tertiary education? Why or why not? (Some social beliefs; woman gains a job harder than man, woman gets less salary than man, woman is in a lower position than man, working quality of woman is less than man, etc.).

16) With the same supports between man and woman, do you think, who is going to be more successful in the study? Why or why not?

17) How do you feel when girls have to spend a lot of time on their household chores while their peer man playing sports/with friends or do what they want?

18) Do you think that man has more chance on education than woman in your community? Why or why not?

19) Do you think that social norms affect women's education in your community?

Daughter and education

20) What do you think are the main obstacles with your family that might hinder your daughter accessing tertiary education?

Encouraging women on their study

21) What can you do to help your daughter's study?

22) What can your community/government do in order to encourage women on their accessibility of tertiary education?

23) Any recommendation or questions 


\title{
Appendix 6: Request letter for interview appointment
}

\author{
สายาละบะลัด ปะฉ१ขิปะไต ปะฉาใิบลๆอ

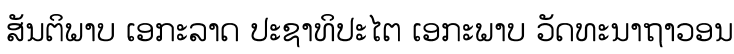 \\ =ニ=ニ=ニ=000 $=======$ \\ บะถงบยูอดอรงจัม, สปป ลาอ \\ มิถุบา 2017
}

ใบสะเขิบ

ธรบ:

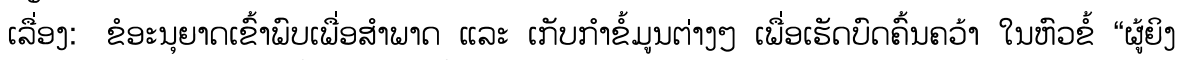

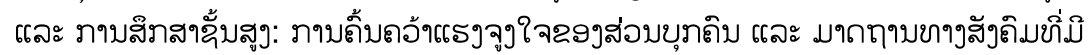

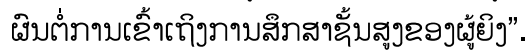

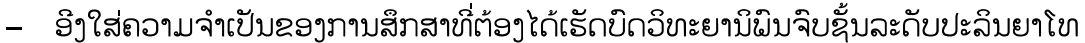

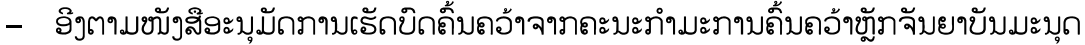

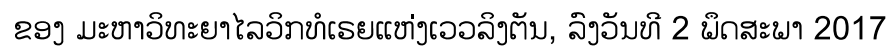

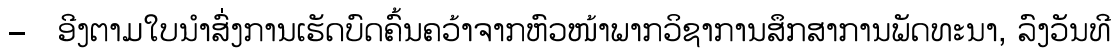
17 ยิถสะฆา 2017

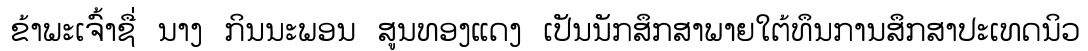
ฉิธเลบ (New Zealand Aid Programme Scholarship) สิภรรม 2016 - 2018

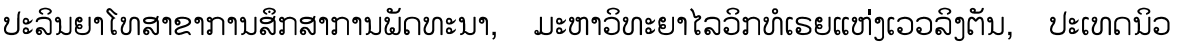

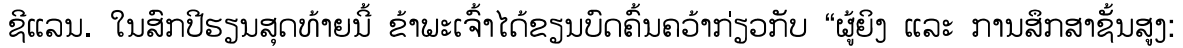

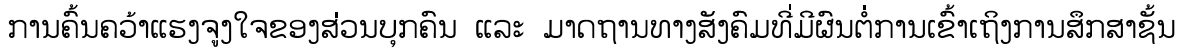

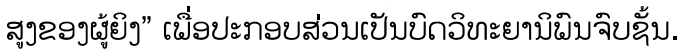

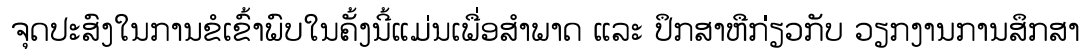

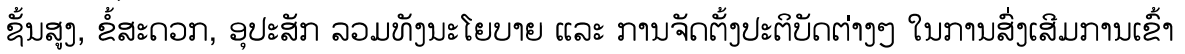

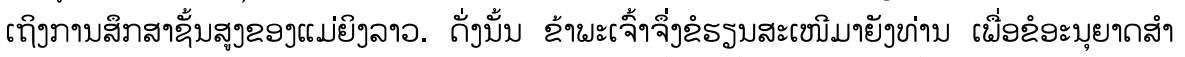

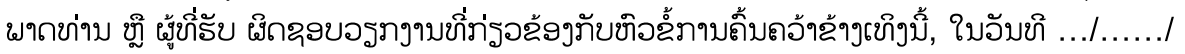
2017, เอลๆ โบต, ขิ่

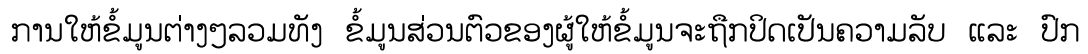

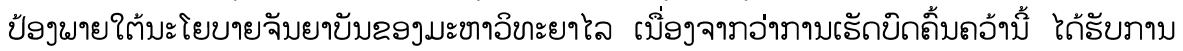

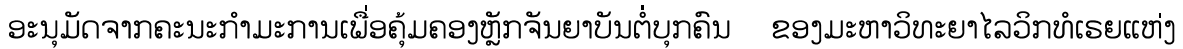
เออล็รตับ. 


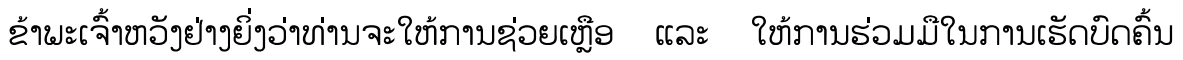
ถอ้าใบถั้งบิ้ถ้อย.

\author{
รรบบาถ้อยถองบเถิาลิบบับฤีย่างสูง. \\ บาต ภิบบะะอบ รูบของตถ \\ บัภสึกสาปะลิยงโขถ้าบทาบสึรสางาบผักขะบๆ
}

เอาะสาบถัดติถ:

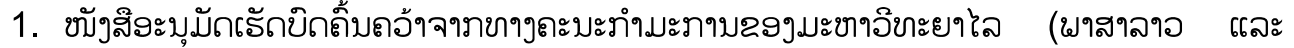
ยาสาอังภํ)

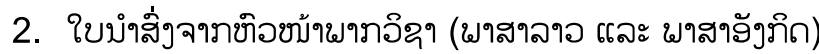

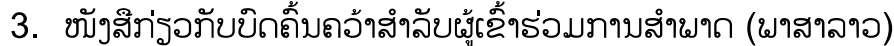

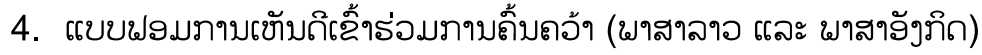

5. ถำฤฯบสำษๆด

สอบฤๆบนั้มูบเผิ่บติ่มใด้ขี่

โขละสับ 02023003673

9ิเมอ: kinnaphone.ny04@gmail.com; sounthkinn@myvwu.ac.nz. 